Review

\title{
Development on Solid Polymer Electrolytes for Electrochemical Devices
}

\author{
Li Ping Teo, Mohd Hamdi Buraidah (1) and Abdul Kariem Arof *
}

check for updates

Citation: Teo, L.P.; Buraidah, M.H.; Arof, A.K. Development on Solid Polymer Electrolytes for Electrochemical Devices. Molecules 2021, 26, 6499. https://doi.org/ $10.3390 /$ molecules26216499

Academic Editor: Maria

Manuela Silva

Received: 10 September 2021

Accepted: 25 October 2021

Published: 28 October 2021

Publisher's Note: MDPI stays neutral with regard to jurisdictional claims in published maps and institutional affiliations.

Copyright: (c) 2021 by the authors. Licensee MDPI, Basel, Switzerland. This article is an open access article distributed under the terms and conditions of the Creative Commons Attribution (CC BY) license (https:// creativecommons.org/licenses/by/ $4.0 /)$.
Centre for Ionics University of Malaya, Physics Department, Faculty of Science, University of Malaya, Kuala Lumpur 50603, Malaysia; lpteo@um.edu.my (L.P.T.); mhburaidah@um.edu.my (M.H.B.)

* Correspondence: akarof@um.edu.my; Tel.: +603-79677143

\begin{abstract}
Electrochemical devices, especially energy storage, have been around for many decades. Liquid electrolytes (LEs), which are known for their volatility and flammability, are mostly used in the fabrication of the devices. Dye-sensitized solar cells (DSSCs) and quantum dot sensitized solar cells (QDSSCs) are also using electrochemical reaction to operate. Following the demand for green and safer energy sources to replace fossil energy, this has raised the research interest in solid-state electrochemical devices. Solid polymer electrolytes (SPEs) are among the candidates to replace the LEs. Hence, understanding the mechanism of ions' transport in SPEs is crucial to achieve similar, if not better, performance to that of LEs. In this paper, the development of SPE from basic construction to electrolyte optimization, which includes polymer blending and adding various types of additives, such as plasticizers and fillers, is discussed.
\end{abstract}

Keywords: solid polymer electrolytes; ionic conductivity; ionic transport; plasticizers; fillers; electrochemical devices

\section{Introduction}

In any electrochemical devices, the electrolyte is viewed as the core constituent separating the cathode and anode, and it serves as the medium for charge transport. The electrolytes in electrochemical cells exist in three forms, viz liquid, gel and solid. Liquid electrolytes (LEs) are usually found to be highly conducting; thus, they are favored in all kinds of electrochemical devices, namely lithium-ion batteries, dye-sensitized solar cells (DSSCs), quantum dot sensitized solar cells (QDSSCs), fuel cells, electrochemical double layer capacitors (EDLCs), electrochromic devices (ECDs) and so on. However, LEs are sometimes volatile and vulnerable to evaporation, leakage and corrosion in the long-term. This will lead to stability and safety issues of the electrochemical devices. Moreover, LEs can also cause the formation of solid electrolyte interphase (SEI) at the anode surface not only in Li-ion batteries but also for all alkali-metal-ion batteries. This can bring adverse effects on their performance. On the other hand, gel-type electrolytes that inherit both characteristics from electrolytes in liquid and solid forms can reduce complications due to safety, but they suffer from structural instability and low mechanical property. Hence, electrolytes in the solid state are the better and more trustworthy choice to resolve the safety problems without compromising the structural and mechanical traits.

Solid polymer electrolyte (SPE), which is fundamentally made up from dissolved conducting salt within the polymer host, was first discovered by three polymer chemists from Sheffield, UK, i.e., Fenton, Parker and Wright, about 48 years ago [1]. Then, in 1978, Armand and co-workers [2] envisioned the promising implementation of SPE in solid-state batteries. Since then, research on SPE has improved tremendously. In order for SPE to be utilized in electrochemical devices, it must have reasonably good ionic conductivity, good chemical, and thermal and mechanical stabilities, as well as good interfacial contact with electrodes. SPE is considered safe, due to the absence of volatile and flammable solvents, as well as flexible, since it can accommodate volume changes in electrodes 
during charging/discharging reactions of electrochemical cells (namely in Li-ion batteries). Furthermore, SPE can be prepared in various shapes and desired designs to meet the needs of electrochemical devices. It can be prepared as an ultra-thin membrane which is lightweight, thus offering promising high energy and power density. SPE is unique compared to liquid electrolyte in the sense that the polymer matrix is in charge for the solvation of ions, while the ions are located at sites which are flexible and can travel within the polymer segments. In order to be functional in electrochemical devices, the SPE must fulfil some prerequisites [3]:

i. Good ambient ionic conductivity of the order between $10^{-4}$ and $10^{-2} \mathrm{~S} \mathrm{~cm}^{-1}$.

ii. Wide electrochemical stability window.

iii. Mechanically stable in order to be safe and durable for devices operation

iv. Thermally stable when in contact with electrode components.

v. Chemical and electrochemical compatibility with electrodes.

vi. Obtainability - the raw materials should be abundantly found and low-priced.

A basic SPE contains a polymer and a salt. The salt is dispersed in the polymer matrix, and the ions can conduct through the polymer chains. In order for the polymer to function as host in polymer electrolytes, the macromolecules must possess polar groups which have lone-pair electrons for dative bonding with the cation from the salt. Both synthetic and natural polymers can serve as polymer matrices in SPEs as long as they have functional group(s) to fulfil the complexation criterion. Various polymer electrolytes have been developed from polymers, such as poly(ethylene oxide) (PEO) [1,4,5], cellulose [6], polyvinylidene fluoride (PVDF) [7], poly(vinyl alcohol) (PVA) [8], polyacrylonitrile (PAN) [9], chitosan [10], poly(methyl methacrylate) (PMMA) [11], starch [12] and poly(vinylidene fluoride-hexafluoropropylene) (PVDF-HFP) [13], to name a few. This review presents some achievements on both the synthetic polymers and biopolymers as polymer host in SPEs used, along with working and counter electrodes in various electrochemical devices namely lithium-ion batteries, sodium-ion batteries, DSSCs, QDSSCs, fuel cells, supercapacitors, EDLCs, ECDs, proton-conducting batteries and proton-exchange membrane fuel cells (PEMFCs). Here, we pay special attention to the conductivity aspect of SPEs in these electrochemical devices. Different types of approaches taken by researchers to improve the ionic conductivity of SPEs are also discussed.

\section{Ion Transport Properties and Conduction Mechanism in SPEs}

Ionic conductivity is one vital characteristic in determining whether the SPE is practical and efficient for device applications. The ionic conductivity of an electrolyte is calculated by using the bulk resistance from the Nyquist impedance plot. The electrolyte is subjected to a small potential typically $10 \mathrm{mV}$ to ensure a linear current-voltage relationship for impedance measurement. According to the Nernst-Einstein relationship, the ionic conductivity, $\sigma$, is directly proportional to the diffusion coefficient of ions, $D$, as shown in the following equation:

$$
\sigma=\frac{q^{2} n}{k_{b} T} D
$$

where $q$ is elementary charge, $n$ is the number of ions, $k_{b}$ is Boltzmann constant and $T$ is temperature. Since the electrolyte consists of salts that can ionize into cations and anions, Equation (1) can be written as follows:

$$
\sigma=\sigma_{+}+\sigma_{-}=\frac{q^{2}}{k_{b} T}\left(n_{+} D_{+}+n_{-} D_{-}\right)
$$

where $\sigma_{+}$and $\sigma_{-}$are the ionic conductivity of cations and anions respectively, $n_{+}$is the number of cations, $n_{-}$is the number of anions, $D_{+}$is the cationic diffusion coefficient and $D_{-}$is the anionic diffusion coefficient. The movement of ions are varied in the electrolyte systems depending on the solvation environment (liquid, solid and gel). 
As aforementioned, a polymer electrolyte generally consists of inorganic salts solvated in a polymer matrix that contains functional groups, such as $-\mathrm{OH},-\mathrm{C}=\mathrm{O},-\mathrm{NH}_{2}$ and $-\mathrm{COC}-$. The functional groups help to solvate salts into ions via electrostatic interaction. It has been acknowledged for the past three decades that the motion of ions in polymer matrix is coupled with the segmental movement of the polymer chains, and this is described as the Brownian motion by many researchers [14]. Therefore, it is believed that the ion movements can only occur in amorphous polymers where the polymer chains are freely moveable to transport the ions. It is well-known that the motion and flexibility of polymer chains are higher in polymer matrix that possess low glass transition temperature, $T_{\mathrm{g}}$. Hence, the selection of polymer is crucial in the development of polymer electrolyte. The relation between conductivity and $T_{\mathrm{g}}$ can be explained by the Vogel-Tammann-Fulcher (VTF) equation:

$$
\sigma=\sigma_{o} T^{1 / 2} \exp \left(\frac{-B}{T-\left(T_{g}-50 \mathrm{~K}\right)}\right)
$$

where $\sigma_{o}$ is the prefactor and $B$ is related to the activation energy. $T_{\mathrm{g}}$ can also be determined from differential scanning calorimetry (DSC). Based on Equations (2) and (3), the conductivity of a polymer electrolyte can be amplified by increasing the number density of mobile ions and lowering the $T_{\mathrm{g}}$. Another approach is by decoupling ion diffusion with the polymer chains. A simplest way to fulfil the above criteria is by adding high dielectric constant plasticizers into the polymer electrolyte. A high dielectric constant can weaken the attraction forces between the ions in the salt and thus enhances the salt dissociation and the increase in number density of mobile ions [3]. Plasticizers also facilitate the pathway of ions transportation by increasing the amorphousness of the polymer electrolyte film and providing the additional coordination sites for ions to conduct.

Whu and Wick [4] have investigated the role of propylene carbonate (PC) as plasticizer in PEO-based electrolytes having lithium bis(trifluoromethanesulfonyl)imide (LiTFSI) via Monte Carlo and molecular dynamics simulations. They found that the conductivity showed significant improvement with the addition of PC due to the increase in mobility of TFSI ${ }^{-}$ions [4]. The lithium ions' diffusion remained unchanged and showed stronger interaction with the ethylene oxide oxygen as compared to the carbonate oxygen. Radial distribution function of lithium also showed weak binding between lithium and oxygen atom of TFSI $^{-}$in the presence of PC [4]. Therefore, the probability of lithium ions' transportation through the oxygen atom of $\mathrm{PEO}$ was higher than that of carbonate and $\mathrm{TFSI}^{-}$ oxygen [4].

Webb and co-workers [5] calculated the diffusion of lithium ions in different types of polymers, namely PEO, poly(methylene oxide) (PMO), poly(propylene oxide) (PPO), poly(trimethylene oxide) (PTMO), poly(ethylene oxide-alt-methylene oxide) (P(EO-MO)) and poly(ethylene oxide-alt-trimethylene oxide) (P(EO-TMO), using molecular dynamics and dynamic bond percolation models. They have assigned short molecular dynamics trajectories to identify the distribution of the solvation sites and used it in dynamic bond percolation model to calculate the ionic hopping rate. According to them, the largest number of site density belongs to the polymer with the highest oxygen atom content which is $\mathrm{PMO}$ (oxygen to carbon atomic ratio is $1: 1$ ). This is followed by $\mathrm{P}(\mathrm{EO}-\mathrm{MO})(2: 3), \mathrm{PEO}$ (1:2), P(EO-TMO) (2:5), PPO (1:3) and PTMO (1:3). Even though the ratio of oxygen to carbon atoms for PPO and PTMO are the same, the site density is slightly higher in PPO which may be due to the arrangement of atoms in the PPO [5]. The rate of hopping sites, $k_{0}$, with distance, $r$, can be calculated by using the following equation:

$$
k_{0}(r)=\tau^{-1} e^{-E_{d i s}(r) / k_{b} T} e^{-E_{\lambda}(r) / k_{b} T}
$$

where $\tau^{-1}$ is frequency, and $E_{d i s}$ and $E_{\lambda}$ are the dissociation and reorganization energies, respectively. Based on the calculation, the authors found that PMO exhibited the smallest value of $k_{0}$, whereas that of PPO was the largest [5]. They have used these values to 
calculate lithium-ion diffusion, using the kinetic Monte Carlo simulation. Among the polyethers studied, the diffusion of lithium ions in P(EO-TMO) was the highest [5].

Diffusion coefficient of ions, $D$, can also be determined from the following equation:

$$
D=\frac{d^{2}}{4 \tau_{2} \delta^{2}}
$$

where $d$ is the thickness of the electrolyte, $\tau_{2}=1 / \omega$ and $\delta=d k^{-1} / A \varepsilon \varepsilon_{0}$ (where $\omega$ is the angular frequency taken at the minimum value of impedance in Bode plot; $k^{-1}$ is double layer capacitance; $\varepsilon$ is dielectric constant of the electrolyte; and $\varepsilon_{0}$ is the permittivity in free space). Based on Equation (5), D in PVA-based polymer electrolyte containing potassium iodide salt has been calculated [6]. The $k^{-1}$ value was obtained by fitting the Nyquist plot of the electrolyte. Since the complex impedance plot shows only a tilted spike, the plot has been fitted based on the series connection of bulk resistance, $R_{b}$, and constant phase element, CPE.

The total impedance (real, $Z^{\prime}$ and imaginary, $Z^{\prime \prime}$ ) can be described as follows:

$$
\begin{gathered}
Z^{\prime}=R_{b}+\cos (\pi p / 2) / k^{-1} \omega^{p} \\
Z^{\prime \prime}=\sin (\pi p / 2) / k^{-1} \omega^{p}
\end{gathered}
$$

where $p$ is a fraction of a right angle. The mobility, $\mu$, and number density, $n$, of ions can be obtained by using the following equations:

$$
\begin{gathered}
\mu=q D / k_{b} T \\
n=\sigma / q \mu
\end{gathered}
$$

It is evident that Equation (1) is the combination of Equations (8) and (9). The calculated transport properties $(D, n$ and $\mu$ ) have been used to explain the conductivity behavior in PVA-based electrolyte containing different salt concentrations [8]. Relationship between $\sigma, n$ and $\mu$ can be expressed as follows:

$$
\sigma=q n \mu
$$

In our earlier studies [8], it was found that the ionic mobility has contributed more in the highest conducting electrolyte, since $n$ decreased due to the establishment of ion pairs and ionic aggregates. Noor has calculated $n$ for lithium triflate in gellan-gum-based SPE by using the method from Fourier transform infrared (FTIR) spectroscopy [9,15]. Areas of free ions $\left(A_{f}\right)$, ion pairs $\left(A_{p}\right)$ and ion aggregates $\left(A_{a}\right)$ have been identified via FTIR deconvolution in wavenumber region between 1030 and $1060 \mathrm{~cm}^{-1}$, and their percentage can be calculated based on the following equations:

$$
\begin{gathered}
\text { Free ions }(\%)=\frac{A_{f}}{A_{f}+A_{p}+A_{a}} \times 100 \\
\text { Ion pairs }(\%)=\frac{A_{p}}{A_{f}+A_{p}+A_{a}} \times 100 \\
\text { Ion aggregates }(\%)=\frac{A_{a}}{A_{f}+A_{p}+A_{a}} \times 100
\end{gathered}
$$

From Equation (11), $n$ can be calculated from the following:

$$
n=\frac{M \times N_{A}}{V} \times 2 \times \text { percentage of free ions }
$$

where $N_{A}$ is the Avogadro's number, $M$ is number of moles of lithium triflate and $V$ is the electrolyte's volume. 
The $n$ value can also be calculated from the famous Rice and Roth model which was originally developed to describe the conductivity behavior for superionic conductors [16]. The equation is as follows:

$$
\sigma=\frac{2}{3}\left[\frac{(Z q)^{2}}{m k_{b} T}\right] n E_{A} \tau \exp \left[-\frac{E_{A}}{k_{b} T}\right]
$$

where $E_{A}$ is the activation energy; $q$ is the electron charge; $m$ is the mass of ions; $Z$ is the vacancy of conducting species; and $\tau=r / \nu$, where $r$ is the distance between two coordinating sites and $v$ is the velocity of ions, which is given as follows:

$$
v=\sqrt{\frac{2 E_{A}}{m}}
$$

$E_{A}$ is the minimum energy required for an ion to hop in between sites, and it can be obtained from the Arrhenius equation, as shown below:

$$
\sigma=\sigma_{0} \exp \left(\frac{E_{A}}{k_{b} T}\right)
$$

where $\sigma_{0}$ is the pre-exponential factor. A low $E_{A}$ value is required for high conductivity. In general, the mechanism of ion transport in polymer electrolytes is via hopping and coupled with the segmental motion of the polymer [3]. However, Grotthuss motion which is another type of hopping mechanism has been proposed to describe proton conduction in chitosanbased SPE containing ammonium iodide $\left(\mathrm{NH}_{4} \mathrm{I}\right)$ [10]. Chitosan structure is rigid and possesses high $T_{g}$, thus resulting in minimal chain motion. This led to the proposal of the Grotthuss model as the proton-conduction mechanism in the SPEs. Grotthuss mechanism is the proton conduction process where the proton hops between the coordination sites decoupled from the polymer chain motion. This mechanism is also known as proton hopping. Besides these factors, other parameters that can influence the feasibility of polymer electrolytes in applications for electrochemical cells include ion (cationic and anionic) transference number $\left(t_{\text {ion }}\right)$, degree of crystallinity, etc.

\section{Basic Solid Polymer Electrolytes}

A simple SPE consists of a polymer and a salt where both are dissolved in a solvent before the solvent is allowed to evaporate, while the ions continue to be free and mobile inside the polymer matrix [3]. The salt can be either inorganic or organic salt but when used in DSSCs application, the SPE must contain additional materials, i.e., iodine $\left(\mathrm{I}_{2}\right)$ crystals to act as redox mediator, while the salt must be iodide-based salts, since iodide/triiodide $\left(\mathrm{I}^{-} / \mathrm{I}_{3}{ }^{-}\right)$redox couple is commonly used [17]. Likewise, for application in QDSSCs, the basic SPE should have sulfide/polysulfide $\left(\mathrm{S}^{2-} / \mathrm{S}_{\mathrm{x}}{ }^{2-}\right)$ redox mediator with sulfide-based salts. Similarly, the salt should be lithium-based, sodium-based, magnesium-based and proton-based if it is going to be employed in cells of Li-ion, $\mathrm{Na-ion}$ and $\mathrm{Mg}$-ion and proton batteries as well as PEMFCs. Besides this, the salt must meet the criterion of having low lattice energy for easy solvation in polymer matrix [3]. Tables 1 and 2 list some of the most popular polymers and salts used in polymer electrolytes, along with their special traits that enable them to be favored among others by the researchers worldwide. The $T_{g}$ of polymer will affect the crystallinity of the electrolytes, and usually low $T_{g}$ is preferred. Meanwhile, the lattice energy of salt will determine how easy it can dissociate in the polymer matrix. The lattice energies of the salts in Table 2 are calculated in this work, using the Kapustinskii equation [18]. All materials have both their own benefits and drawbacks. For instance, PEO, being the first polymer host used in polymer electrolytes and still remaining one of the most popular polymers until now, is favored for its talent to solvate many types of salts and exhibit good mechanical strength and thermal stability. It is a semicrystalline macromolecule, and thus, its crystalline part restricts the increment of conductivity. As for 
the salts, lithium perchlorate $\left(\mathrm{LiClO}_{4}\right)$, as an example, shows good ionic conductivity, but it is a strong oxidizer, hence making it explosive, and so it must be handled with caution. As for the solvent choice, certain features, including dielectric constant, melting point, boiling point and viscosity, have to be taken into consideration for salt dissociation and solvation of polymer. Some frequently employed solvents are summarized in Table 3, along with their physical attributes.

Table 1. Typical polymers used in polymer electrolytes, along with their characteristics.

\begin{tabular}{|c|c|c|c|}
\hline Polymer & Functional Group(s) & $\begin{array}{c}\text { Glass Transition } \\
\text { Temperature, } T_{g}\left({ }^{\circ} \mathrm{C}\right)\end{array}$ & Reference \\
\hline Poly(ethylene oxide) (PEO) & Ether & -64 & [19] \\
\hline Polyacrylonitrile (PAN) & Nitrile & 125 & {$[19,20]$} \\
\hline Poly(vinyl alcohol) (PVA) & Hydroxyl & 82 & {$[21]$} \\
\hline Cellulose & Hydroxyl, Ether & 220 & [22] \\
\hline Poly(methyl methacrylate) (PMMA) & Ester, Carbonyl & 105 & [19] \\
\hline Polyethyl methacrylate (PEMA) & Ester, Carbonyl & 63 & {$[23]$} \\
\hline Polyvinylidene fluoride (PVDF) & Difluoromethylene & -40 & [19] \\
\hline Chitosan & Hydroxyl, Amine, Ether & 203 & {$[24]$} \\
\hline $\begin{array}{l}\text { Poly(vinylidene fluoride-hexafluoropropylene) } \\
\text { (PVDF-HFP) }\end{array}$ & Difluoromethylene & -90 & [19] \\
\hline Starch & Hydroxy, Ether & 70 & [25] \\
\hline
\end{tabular}

Table 2. Some popular salts used in polymer electrolytes, along with their properties [18,26,27].

\begin{tabular}{|c|c|c|c|}
\hline Salt & $\begin{array}{c}\text { Cationic Radii } \\
\text { (pm) }\end{array}$ & $\begin{array}{l}\text { Anionic Radii } \\
\text { (pm) }\end{array}$ & 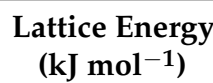 \\
\hline $\begin{array}{l}\text { Lithium bis(trifluoromethanesulfonyl)imide }\left(\left(\mathrm{LiN}\left(\mathrm{CF}_{3} \mathrm{SO}_{2}\right)_{2}\right) \text { or }\right. \\
\text { (LiTFSI) }\end{array}$ & 60 & 328 & 564 \\
\hline Lithium trifluoromethanesulfonate or lithium triflate $\left(\mathrm{LiCF}_{3} \mathrm{SO}_{3}\right)$ & 60 & 268 & 730 \\
\hline Lithium perchlorate $\left(\mathrm{LiClO}_{4}\right)$ & 60 & 234 & 718 \\
\hline Lithium tetrafluoroborate $\left(\mathrm{LiBF}_{4}\right)$ & 60 & 227 & 735 \\
\hline Lithium hexafluorophosphate $\left(\mathrm{LiPF}_{6}\right)$ & 60 & 254 & 681 \\
\hline Sodium iodide $(\mathrm{NaI})$ & 102 & 216 & 674 \\
\hline Sodium thiocyanate (NaSCN) & 102 & 213 & 680 \\
\hline Ammonium iodide $\left(\mathrm{NH}_{4} \mathrm{I}\right)$ & 143 & 216 & 605 \\
\hline Lithium iodide (LiI) & 60 & 216 & 762 \\
\hline
\end{tabular}

Table 3. Physical properties of some solvents [28-30].

\begin{tabular}{|c|c|c|c|c|c|}
\hline Solvent & $\begin{array}{c}\text { Donor } \\
\text { Number, DN }\end{array}$ & $\begin{array}{c}\text { Dielectric Constant, } \\
\varepsilon \text { at } 25^{\circ} \mathrm{C}\end{array}$ & $\begin{array}{c}\text { Viscosity }(\mathrm{cP}) \\
\text { at } 25^{\circ} \mathrm{C}\end{array}$ & $\begin{array}{l}\text { Melting Point, } \\
T_{m}\left({ }^{\circ} \mathrm{C}\right)\end{array}$ & $\begin{array}{c}\text { Boiling } \\
\text { Point }\left({ }^{\circ} \mathrm{C}\right)\end{array}$ \\
\hline Acetone & 17.0 & 20.6 & 0.30 & -94.7 & 56.1 \\
\hline Acetonitrile $(\mathrm{ACN})$ & 14.1 & 35.9 & 0.37 & -43.8 & 81.6 \\
\hline N-methyl-2-pyrrolidone (NMP) & 27.3 & 32.2 & 1.67 & -24.4 & 202 \\
\hline Tetrahydrofuran (THF) & & 7.58 & 0.46 & -108.4 & 60 \\
\hline N,N-Dimethylacetamide (DMAc) & 27.8 & 37.8 & 0.93 & -20 & 166.1 \\
\hline Dimethyl sulfoxide (DMSO) & 29.8 & 46.5 & 1.99 & 18.5 & 189 \\
\hline Gamma-butyrolactone (gBL) & 18.0 & $39.0^{+}$ & 1.70 & -44 & 204 \\
\hline N,N-Dimethylformamide (DMF) & 26.6 & 36.1 & 0.80 & -61 & 153 \\
\hline Ethylene carbonate (EC) & 16.4 & $89 *$ & $1.90 *$ & 36 & 238 \\
\hline Propylene carbonate (PC) & 15.1 & 64 & 2.50 & -49 & 241 \\
\hline Ethanol & 19.2 & 25 & 1.08 & -114 & 78 \\
\hline Water & 18.0 & 78 & 0.89 & 0 & 100 \\
\hline
\end{tabular}




\subsection{Preparation Methods of SPEs}

SPEs can be prepared via several methods, including solution casting [31], phase inversion [32], photopolymerization [33] and electrospinning [31] techniques, to name a few. Solution cast or solvent casting method is the most conventional and easy way to prepare electrolyte film. In this procedure, the polymer and salt are dissolved in an appropriate solvent before casting onto suitable substrates (e.g., glass plates). The solvent is then evaporated after being left to dry either at ambient condition or elevated temperature inside oven. Solution casting route can be performed at room temperature atmosphere or inside glove box, depending on its needs. After complete drying, the SPE is a free standing membrane with thickness usually in millimeter range. Solangi and co-authors [31] have compared PVA-based SPE containing potassium iodide (KI), potassium chloride $(\mathrm{KCl})$ and sodium chloride $(\mathrm{NaCl})$ salts prepared by using electrospinning and solution-casting techniques. Regardless of which salt was used, the electrolyte fabricated via the former method demonstrated superior ionic conductivity $\left(5.95 \times 10^{-6} \mathrm{~S} \mathrm{~cm}^{-1}\right.$ for NaCl-containing $\mathrm{SPE})$ than that prepared by the latter $\left(1.87 \times 10^{-6} \mathrm{~S} \mathrm{~cm}^{-1}\right.$ for SPE having $\left.\mathrm{NaCl}\right)$ [31]. The electrospinning approach can produce film of fibers morphology with a large surface-areato-volume ratio. Moreover, the electrospun membranes were more thermally stable than the solution-cast prepared films. Among the three salts, electrolytes comprising $\mathrm{NaCl}$ exhibited the highest conductivity irrespective of the preparation method [31]. Nonetheless, there are many parameters that need to be controlled and optimized in electrospinning process such as polymer molecular weight and solution viscosity, conductivity and surface tension. Furthermore, the electrospinning setup conditions, e.g., flow rate, applied voltage and distance from tip of syringe containing solution to collector, are tedious and time-consuming. In contrast to electrospinning, the solution-casting route is a more straightforward and convenient approach for membrane preparation.

The phase inversion technique can produce porous structure which is beneficial for ionic transport. Using this method, SPE membrane consisting of PDVF-HFP, $\mathrm{LiClO}_{4}$ and cerium oxide $\left(\mathrm{CeO}_{2}\right)$ exhibited sponge-like morphology with tiny pores and ionic conductivity of $2.50 \times 10^{-3} \mathrm{~S} \mathrm{~cm}^{-1}$ at $25^{\circ} \mathrm{C}$ [32]. In this procedure, a solution containing PVDF-HFP, $\mathrm{CeO}_{2}$ and NMP solvent was stirred for $24 \mathrm{~h}$ before being coated onto a glass plate via the doctor-blade method. This was followed by immersion in deionized water (about 3 to $5 \mathrm{~h}$ ) for solvent extraction and phase inversion, which took place before drying under vacuum-pressure condition. The last step was to soak the membrane in $\mathrm{LiClO}_{4}$ liquid electrolyte for $6 \mathrm{~h}$ [32]. Liu et al. [34] have combined phase-inversion and chemical-reaction routes to obtain PVDF-PAN-SiO $-\mathrm{LiPF}_{6} \mathrm{SPE}$ membrane that gave ambient conductivity of $3.32 \times 10^{-3} \mathrm{~S} \mathrm{~cm}^{-1}$. For comparison, the same composition membrane has been prepared by phase-inversion method, and it was found that the ambient conductivity was $2.83 \times 10^{-3} \mathrm{~S} \mathrm{~cm}^{-1}$ [34]. The higher conductivity obtained by the membrane prepared by the combined method was attributed to larger porosity and better homogeneous pores distribution as compared to that developed from the phase-inversion technique only [34]. The former also showed better properties in terms of heat resistance, mechanical strength and electrochemical stability than the latter [34]. An unconventional way to prepare SPE films is through dry-mixing without the use of solvent. Dry-mixing is combined with hot-pressing. Eriksson et al. [35] have obtained thin films of SPEs containing poly(3,3dimethylpentane-2,4-dione) as the polymer matrix and LiTFSI salt after pressing the dried homogenous mixture between two polytetrafluoroethylene (PTFE) plates, under high pressure $(2 \mathrm{MPa})$ and temperature $\left(100^{\circ} \mathrm{C}\right)$ conditions, inside an argon-filled glove box for $1 \mathrm{~h}$. The polymer was desiccated in vacuum state before uniformly mixing and pulverizing the polymer and salt. Although the ambient conductivity value was low, of the order of $10^{-8} \mathrm{~S} \mathrm{~cm}^{-1}$, it gave a rather high $\mathrm{Li}^{+}$ion transference number $\left(t_{\mathrm{Li+}}=0.70\right)$ at $80^{\circ} \mathrm{C}$ [35]. For the sake of comparison, the LiTFSI-containing SPE but with PEO as polymer host has been prepared by the same method and it showed a higher ambient conductivity $\left(10^{-5} \mathrm{~S} \mathrm{~cm}^{-1}\right)$ with low $\mathrm{Li}^{+}$transference number $\left(t_{L i+}=\sim 0.15\right)$ [35]. High cationic transference number 
is useful for application in Li-ion batteries. Table 4 shows some selected works of simple SPEs systems available in the literature.

Table 4. Basic SPEs films, along with their conductivity and significant properties.

\begin{tabular}{|c|c|c|c|c|}
\hline Electrolyte System & $\begin{array}{l}\text { Preparation } \\
\text { Method }\end{array}$ & $\begin{array}{l}\text { Conductivity, } \\
\sigma\left(\mathrm{S} \mathrm{cm}^{-1}\right)\end{array}$ & Important Findings & Reference \\
\hline PEO-NaSCN & Solution casting & $\begin{array}{l}9.86 \times 10^{-8} \\
(\mathrm{RT})\end{array}$ & $\begin{array}{c}t_{\text {ion }}=0.85 \\
n=1.21 \times 10^{20} \mathrm{~m}^{-3} \\
\mu=5.10 \times 10^{-7} \mathrm{~m}^{2} \mathrm{~V}^{-1} \mathrm{~s}^{-1}\end{array}$ & [36] \\
\hline $\begin{array}{l}\mathrm{PEO}-\mathrm{NaFNFSI} \\
{[\mathrm{EO}] /[\mathrm{Na}]=15}\end{array}$ & Solution casting & $\begin{array}{l}3.16 \times 10^{-6} \\
\left(80^{\circ} \mathrm{C}\right) \\
3.36 \times 10^{-4} \\
\left(30^{\circ} \mathrm{C}\right)\end{array}$ & $\begin{array}{c}\text { Thermal stability }>300{ }^{\circ} \mathrm{C} ; \mathrm{T}_{g}=-36.3^{\circ} \mathrm{C} \\
t_{\mathrm{Na}+}=0.24\left(80{ }^{\circ} \mathrm{C}\right) \\
\text { Oxidation potential }=4.87 \mathrm{~V} \text { vs Na}{ }^{+} / \mathrm{Na} \\
\mathrm{NaCu}_{1 / 9} \mathrm{Ni}_{2 / 9} \mathrm{Fe}_{1 / 3} \mathrm{Mn}_{1 / 3} \mathrm{O}_{2} / \mathrm{SPE} / \mathrm{Na} \text { cell: } \\
\text { Initial capacity }=122.4 \mathrm{mAh} \mathrm{g}^{-1}\left(0.1 \mathrm{C}, 80{ }^{\circ} \mathrm{C}\right) 70 \% \\
\text { capacity retention at } 1 \mathrm{C} \text { after } 150 \text { cycles }\left(80^{\circ} \mathrm{C}\right)\end{array}$ & [37] \\
\hline $\mathrm{PEO}-\mathrm{LiCF}_{3} \mathrm{SO}_{3}$ & $\begin{array}{l}\text { Ball-milling and } \\
\text { hot press }\end{array}$ & $1.00 \times 10^{-6}$ & $T_{g}=-64.4{ }^{\circ} \mathrm{C} ; \% \chi_{C}=37.3 \%$ & [38] \\
\hline PAN-LiTFSI & Solution casting & $\begin{array}{l}2.54 \times 10^{-4} \\
\left(25^{\circ} \mathrm{C}\right)\end{array}$ & $\begin{array}{c}\% \chi_{\mathrm{C}}=9.3 \% \\
\mathrm{ITO}-\mathrm{WO}_{3} / \mathrm{SPE} / \mathrm{CeO}_{2}-\mathrm{TiO}_{2}-\mathrm{ITO} \mathrm{ECD}: \\
\text { Cathodic coloration at }-1.25 \mathrm{~V} \\
\text { Anodic bleaching at }-0.40 \mathrm{~V}\end{array}$ & [39] \\
\hline $\mathrm{CMC}-\left(\mathrm{NH}_{4}\right)_{2} \mathrm{CO}_{3}$ & Solution casting & $\begin{array}{l}7.71 \times 10^{-6} \\
\left(30^{\circ} \mathrm{C}\right)\end{array}$ & $\begin{aligned} & \% \chi_{C}=30.9 \% ; t_{i o n}=0.98 \\
& \text { CMC film without salt: } \sigma=10^{-9} \mathrm{~S} \mathrm{~cm}^{-1}\end{aligned}$ & {$[40]$} \\
\hline $\mathrm{NaCMC}-\mathrm{Na}_{2} \mathrm{~S}-\mathrm{S}$ & Solution casting & $\begin{array}{l}2.79 \times 10^{-5} \\
\left(30^{\circ} \mathrm{C}\right)\end{array}$ & $\begin{array}{c}E_{A}=0.38 \mathrm{eV} \\
n=15.24 \times 10^{18} \mathrm{~cm}^{-3} \\
\mu=11.44 \times 10^{-6} \mathrm{~m}^{2} \mathrm{~V}^{-1} \mathrm{~s}^{-1} \\
D=2.94 \times 10^{-7} \mathrm{~cm}^{2} \mathrm{~s}^{-1} \\
\mathrm{TiO}_{2}-\mathrm{CdS}-\mathrm{ZnS} / \mathrm{SPE} / \mathrm{Pt} \text { QDSSC (light intensity of } \\
\left.100 \mathrm{~mW} \mathrm{~cm} \mathrm{~cm}^{-2}\right): \\
\mathrm{OCV}=0.41 \mathrm{~V} ; J_{S c}=4.92 \mathrm{~mA} \mathrm{~cm}{ }^{-2} \\
F F=0.45 ; \eta=0.90 \%\end{array}$ & [41] \\
\hline Pectin-LiCl & Solution casting & $\begin{array}{l}1.96 \times 10^{-3} \\
\left(30^{\circ} \mathrm{C}\right)\end{array}$ & $\begin{array}{c}E_{A}=0.23 \mathrm{eV} \\
\text { Tensile strength }=4.61 \mathrm{MPa} \\
\text { Electrochemical stability window } 3.77 \mathrm{~V} \\
\mathrm{Zn} / \mathrm{SPE} / \mathrm{LiFePO}_{4} \text { cell: } \\
\mathrm{OCV}=1.25 \mathrm{~V}\end{array}$ & [42] \\
\hline $\begin{array}{l}\mathrm{PEO}-\mathrm{LiCF}_{3} \mathrm{SO}_{3} \\
{[\mathrm{EO}] /[\mathrm{Li}]=9: 1}\end{array}$ & Solution casting & $\begin{array}{l}1.40 \times 10^{-6} \\
\left(30^{\circ} \mathrm{C}\right)\end{array}$ & $T_{g}=-39{ }^{\circ} \mathrm{C} ; T_{m}=64{ }^{\circ} \mathrm{C}$ & [43] \\
\hline Sago starch-KI & Solution casting & $\begin{array}{l}3.41 \times 10^{-4} \\
(\mathrm{RT})\end{array}$ & $\begin{array}{c}\text { Dielectric relaxation time }=2.33 \times 10^{-7} \mathrm{~s} \\
\mathrm{~N} 3 / \mathrm{TiO}_{2} / \mathrm{SPE} / \mathrm{Pt} \text { DSSC }(\text { light intensity of } \\
\left.100 \mathrm{~mW} \mathrm{~cm}^{-2}\right): \\
\mathrm{OCV}=0.58 \mathrm{~V} ; J_{S C}=0.29 \mathrm{~mA} \mathrm{~cm}{ }^{-2} \\
F F=0.43 ; \eta=0.57 \%\end{array}$ & {$[44,45]$} \\
\hline Corn starch-MgSO ${ }_{4}$ & Solution casting & $\begin{array}{l}8.52 \times 10^{-5} \\
\left(30^{\circ} \mathrm{C}\right)\end{array}$ & $\begin{array}{l}\text { SEM micrograph of SPE shows rough surface, while } \\
\text { that of starch film without salt shows otherwise. }\end{array}$ & {$[46]$} \\
\hline PEMA-NH ${ }_{4} \mathrm{I}$ & Solution casting & $\begin{array}{l}1.80 \times 10^{-5} \\
\left(30^{\circ} \mathrm{C}\right)\end{array}$ & $\begin{array}{c}t_{i o n}=0.93 \\
\text { Ru-based dye } / \mathrm{TiO}_{2} / \mathrm{SPE} / \mathrm{Pt} \text { DSSC (light intensity of } \\
\left.100 \mathrm{~mW} \mathrm{~cm} \mathrm{~cm}^{-2}\right) \\
\mathrm{OCV}=0.56 \mathrm{~V} ; J_{S C}=1.52 \mathrm{~mA} \mathrm{~cm}^{-2} \\
F F=0.51 ; \eta=0.43 \%\end{array}$ & [47] \\
\hline
\end{tabular}

NaSCN—sodium thiocyanate; RT-room temperature; NaFNFSI-sodium (fluorosulfonyl)(n-nonafluorobutanesulfonyl)imide $\left(\mathrm{Na}\left[\left(\mathrm{FSO}_{2}\right)\left(\mathrm{n}-\mathrm{C}_{4} \mathrm{~F}_{9} \mathrm{SO}_{2}\right) \mathrm{N}\right] ; \% \chi_{\mathrm{C}}\right.$ - degree of crystallinity percentage; $\mathrm{CMC}$ - carboxymethyl cellulose; ITO-indium tin oxide; $\mathrm{WO}_{3}-$ tungsten (VI) oxide; $\mathrm{CeO}_{2}$ - cerium (IV) oxide; $\mathrm{TiO}_{2}$-titanium dioxide; $\left(\mathrm{NH}_{4}\right)_{2} \mathrm{CO}_{3}$-ammonium carbonate; NaCMC-sodiumcarboxymethylcellulose; $\mathrm{Na}_{2} \mathrm{~S}$ — sodium sulfide; $\mathrm{S}$ - sulfur; $\mathrm{OCV}$ - open circuit voltage; $J_{s c}$ — short circuit current density; $F F$ - fill factor; $\eta$-efficiency; CdS—cadmium sulfide; $\mathrm{ZnS}$-zinc sulfide; $\mathrm{Pt}$-platinum; LiCl—lithium chloride; $\mathrm{LiFePO}_{4}$-lithium iron phosphate; N3-cis-bis(isothiocyanato)bis(2,2'-bipyridyl-4,4'-dicarboxylato)ruthenium(II); $\mathrm{MgSO}_{4}$-magnesium sulfate. 


\subsection{Strategies to Improve Ionic Conductivity of SPES}

In order to boost the ionic conductivity of SPEs, there are many approaches which have been taken by researchers, as stated in the following subsections.

\subsubsection{Incorporation of More Than One Salt}

One viable approach to boost the ionic conductivity of SPEs is to add another salt. The combination of two or more salts in the right proportions can give synergistic outcomes. In most cases, the sum concentration of salts is the same as the highest conducting electrolyte that contained only on one type of salt. This means that the total weight of salts remained unchanged, but an appropriate amount for salt one has been substituted by salt two. Since the amount of each salt in a mixed salt electrolytes is lower than the concentration of salt in single-salt electrolyte systems, the probability of ion recombination to form ion pairs will be reduced in former case, and thus, there are more free ions for conduction [48,49]. In addition, decrement in $T_{g}$ and degree of crystallinity $\left(\% \chi_{c}\right)$ of the electrolyte are observed in mixed salt systems [48]. Tao and Fujinami [50] reported that highest conductivity was achieved at $5 \times 10^{-5} \mathrm{~S} \mathrm{~cm}^{-1}\left(30^{\circ} \mathrm{C}\right)$ in PEO-based SPE containing lithium borate and lithium aluminate salts as compared to PEO electrolyte with one salt only regardless which one. Only minimal capacity fading was observed in $\mathrm{LiNi}_{0.8} \mathrm{Co}_{0.2} \mathrm{O}_{2} / \mathrm{Li}$ cell with double salt-containing SPE after 30th cycle, but no results were given for that of single salt [50]. The type of cation and anion determine the electrochemical performance of devices. For Li-ion, $\mathrm{Na}$-ion and Mg-ion cells, it is obvious that dissimilar anions influence the performance of the devices. For DSSCs, the variation of cations since the anion is fixed following the redox mediator used. Studies of mixed salt systems containing different cations [51,52] or dissimilar anions $[49,53,54]$ have shown superior ionic conductivity than single salt systems. For instance, higher conductivity was obtained for an electrolyte based on PEO$\mathrm{CaBr}_{2}-\mathrm{CaI}_{2}$ (30:1:1) than for a PEO-based electrolyte with only one salt, i.e., either calcium iodide $\left(\mathrm{CaI}_{2}\right)$ or calcium bromide $\left(\mathrm{CaBr}_{2}\right)$ [52]. Similarly, enhanced conductivity has been detected for PEO electrolyte having dual salts of zinc bromide $\left(\mathrm{ZnBr}_{2}\right)$ and lithium bromide ( $\mathrm{LiBr}$ [ [51] and PEO-based electrolyte comprising the same compositions of binary salts of copper trifluoromethanesulfonate $\left(\mathrm{Cu}\left(\mathrm{CF}_{3} \mathrm{SO}_{3}\right)_{2}\right)$ and zinc trifluoromethanesulfonate $\left(\mathrm{Zn}\left(\mathrm{CF}_{3} \mathrm{SO}_{3}\right)_{2}\right)$ [55].

The incorporation of double salts does not always warrant higher conductivity than single salt but can still result in better performance of electrochemical devices, since conductivity is not the sole influencing factor. This has been showcased in the work of Dissanayake et al. [56], who have prepared PEO-based SPE with KI and TPAI salts via the solution-cast method. SPE containing sole salt of KI gave higher conductivity than electrolyte having double salts. Conductivity was lowest for electrolyte with lone TPAI salt since its cation is larger than $\mathrm{K}^{+}$and thus less mobile. Moreover, the degree of crystallinity for PEO-TPAI electrolyte was higher than that of PEO-TPAI-KI SPE [56]. DSSC employing hybrid salts displayed the best performance, with an efficiency $(\eta)$ of $4.22 \%$ and short circuit current density $\left(J_{s c}\right)$ of $8.00 \mathrm{~mA} \mathrm{~cm}^{-2}$, followed by cells having single TPAI $\left(J_{s c}=6.38 \mathrm{~mA} \mathrm{~cm}^{-2} ; \eta=3.54 \%\right)$ and $\mathrm{KI}\left(J_{s c}=6.52 \mathrm{~mA} \mathrm{~cm}^{-2} ; \eta=3.09 \%\right)$ under illumination of $100 \mathrm{~mW} \mathrm{~cm} \mathrm{~cm}^{-2}$. Their open-circuit voltage (OCV) values were $0.69,0.77$ and $0.75 \mathrm{~V}$ for KI, TPAI and KI+TPAI electrolytes, respectively [56]. A large-sized cation boosted OCV value, while it reduced $J_{s c}$, as can be seen when comparing the two single salt-containing electrolytes. The addition of a second salt decreased the cation conduction and enhanced $J_{s c}$, leading to a higher $\eta[56]$.

Zhao and co-workers [57] have studied the influence of primary, secondary and ternary salts on PEO-based SPEs incorporated with halloysite nanoclay (HNC) for application in Li-ion batteries. For PEO-LiTFSI-HNC SPEs, the ambient conductivity was $\sim 5.62 \times 10^{-5} \mathrm{~S} \mathrm{~cm}^{-1}$, and there was a slight increment when a secondary salt, i.e., lithium bis(oxalate)borate (LiBOB), was added, but then there was a decrement in conductivity $\left(\sim 1.99 \times 10^{-5} \mathrm{~S} \mathrm{~cm}^{-1}\right)$ was observed with the addition of a third salt, lithium nitrate $\left(\mathrm{LiNO}_{3}\right)$ [57]. Nonetheless, $T_{g}$ values were enhanced from -47.02 to $-40.48{ }^{\circ} \mathrm{C}$ for single 
to ternary salt-containing SPEs [57]. Mechanical strength also improved as proven from dynamic mechanical analysis (DMA). The authors have concluded that each respective salts have their own role with LiTFSI being the main contributor to ionic conduction, whereas the presence of $\mathrm{LiBOB}$ and $\mathrm{LiNO}_{3}$ salts was to ensure the emergence of cathode electrolyte interphase and solid electrolyte interphase SEI on cathode and anode, respectively [57]. Each of these salts have complemented each other and yielded Li-ion-cell performance with better electrochemical stability. Cells employed one and two salts suffered failure within the first five cycles. In contrast, the lithium nickel cobalt manganese oxide (NMC)/Li cell with SPE containing trio salts exhibited the discharge capacity of $\sim 116 \mathrm{mAh} \mathrm{g}^{-1}$ at 60 th cycle [57]

\subsubsection{Modification on Polymer Host}

The partial crystallinity nature of polymer host is usually the main culprit behind the low conductivity of SPEs. This issue can be resolved by making some alteration on the polymer itself. For example, biopolymers, i.e., cellulose and chitin, are highly crystalline with rigid polymer chain backbone, even though they can still serve as host in polymer electrolyte. Cellulose can be chemically modified into methyl cellulose (MC), carboxymethyl cellulose (CMC), hydroxypropyl cellulose (HPC) and sodium carboxymethyl cellulose (NaCMC), to name a few. Similarly, chitosan structure can be altered into carboxymethyl chitosan, hexanoyl chitosan (HCh), N-methylene phosphonic chitosan, chitosan-N-propyl sulfonic acid, etc. Besides reducing crystallinity, the modified polymer will have greater solubility to dissolve in various solvents, as compared to its predecessor. N-phthaloyl chitosan $(\mathrm{PhCh})$ is the product obtained after the chemical adjustment of chitosan in a solution mixture of phthalic anhydride and DMF under a nitrogen gas environment. Chitosan has been successfully transformed into $\mathrm{PhCh}$ with the presence of peaks belonging to the pthalimido functional group at wavenumbers 1713 and $1733 \mathrm{~cm}^{-1}$, as proven by FTIR analysis [58]. Dilute acids of formic, acetic, butyric, lactic, maleic and malic are some solvating agents for chitosan $[59,60]$, but the water content may deteriorate the performance of some electrochemical devices, such as Li-ion batteries and DSSC. PhCh can dissolve in pyridine, DMAc, DMF, DMSO and m-cresol [61,62]. Aziz et al. [58] reported that $\mathrm{PhCh}$ is more amorphous and thermally stable than the antecedent, chitosan. The former requires a higher decomposition temperature $\left(356{ }^{\circ} \mathrm{C}\right)$ than the latter $\left(290{ }^{\circ} \mathrm{C}\right)$. PhCh-based SPE consisting of $\mathrm{NH}_{4} \mathrm{SCN}$ prepared via solution-casting method displayed conductivity of $2.42 \times 10^{-5} \mathrm{~S} \mathrm{~cm}^{-1}$ at $25^{\circ} \mathrm{C}$ and $t_{\text {ion }}=0.91$ [58]. The PhCh film had the ambient conductivity of $\sim 1.93 \times 10^{-10} \mathrm{~S} \mathrm{~cm}^{-1}$ [58]. O-nitrochitosan is another derivative of chitosan after reacting with sodium hydroxide and fumed nitric acid, as synthesized by Rahman et al. [63]. The appearance of new bands at wavenumbers 1355 and $1646 \mathrm{~cm}^{-1}$ were attributed to nitro $(-\mathrm{O}-\mathrm{N}=\mathrm{O})$ functional groups, as evidenced by the FTIR spectrum of o-nitrochitosan [63]. The ambient conductivity was greatly enhanced for the modified chitosan film $\left(5.22 \times 10^{-6} \mathrm{~S} \mathrm{~cm}^{-1}\right)$ at room temperature, while the unmodified chitosan film exhibited low conductivity of $8.88 \times 10^{-10} \mathrm{~S} \mathrm{~cm}^{-1}$ [63]. The large increment was attributed to the high electronegativity of nitro group [63]. Although no dopant salt was incorporated, the authors believed that o-nitrochitosan can be a promising polymer electrolyte membrane in PEMFC [63].

PEO is excellent to solvate $\mathrm{Li}^{+}$ion, which is especially useful for application in Liion cells, even though its crystalline portion hampers the conductivity enhancement. Usually, the conductivity of PEO electrolyte containing lithium salts is no greater than $10^{-4} \mathrm{~S} \mathrm{~cm}^{-1}$ under ambient condition with a low value of lithium-ion transference number $\left(t_{L i+}<0.40\right)$ [64]. Luckily, its chemical structure can be modified and incorporated with various types of functional groups or moieties. Another strategy to improve the conduction of PEO-based electrolyte is to modify its linear chain into hyper-branched structure. Jing et al. [64] have prepared LiTFSI-containing SPE based on PEO having a hyper-branched arrangement and grafting with another PEO of linear chains to improve the ionic conductivity without sacrificing its mechanical strength. An increment by one 
order of magnitude was observed when compared to SPE having PEO linear chain, which was attributed to reduction in crystallinity [64].

Besides polymer modification, the polymer can also undergo copolymerization, grafting, crosslinking and blending with a second polymer in order to lower the crystallization. Imperiyka and co-authors [65] have photo-copolymerized polyglycidyl methacrylate (P(GMA)) with PMMA as the polymer host. SPE with configuration P(GMA-co-MMA)$\mathrm{LiClO}_{4}$ displayed the ambient conductivity of $8.70 \times 10^{-6} \mathrm{~S} \mathrm{~cm}^{-1}$ [65]. The bonding of one polymer chain with that of another polymer is known as a crosslinking reaction. This process can take place physically and chemically (photo-induced polymerization, curing, etc.). In 2016, Lehmann et al. [66] prepared SPE containing PEO ( $\left.\mathrm{M}_{\mathrm{W}} 2000 \mathrm{~g} \mathrm{~mol}^{-1}\right)$ crosslinked with poly(ethyleneimine) (PEI) $\left(\mathrm{M}_{\mathrm{W}} 600 \mathrm{~g} \mathrm{~mol}^{-1}\right)$ and LiTFSI salt and obtained the conductivity of $3.90 \times 10^{-5} \mathrm{~S} \mathrm{~cm}^{-1}$ at $40^{\circ} \mathrm{C}$. The values of $T_{g}$, percentage of crystallinity, tensile strength and cationic transference number were $-33^{\circ} \mathrm{C}, 20 \%, 0.47 \mathrm{MPa}$ and $0.76\left(40^{\circ} \mathrm{C}\right)$, respectively. Meanwhile, SPE, which comprises $600 \mathrm{M}_{\mathrm{w}}$ PEI, with the same salt, attained the conductivity of $1.50 \times 10^{-6} \mathrm{~S} \mathrm{~cm}^{-1}$ at $40{ }^{\circ} \mathrm{C}$ and $T_{g}$ of $-65^{\circ} \mathrm{C}$ [66]. In 2016, Youcef et al. [67] systematically studied the concentration effect of crosslinking agent (divinylbenzene (DVB)) on SPE based on PEO crosslinked poly(ethylene glycol) diacrylate (PEGDA) with LiTFSI salt that had been prepared via polymerization under ultraviolet (UV) irradiation, using a photo-initiator, -hydroxy-2-methylpropiophenone and acetonitrile solvent. At optimum concentration of $10 \% \mathrm{~mol} \mathrm{DVB}$, conductivity of $1.40 \times 10^{-4} \mathrm{~S} \mathrm{~cm}^{-1}$, lithium-ion transference number $\left(t_{L i+}\right)$ of 0.21 and high electrochemical window of $4.30 \mathrm{~V}$ were obtained at $70{ }^{\circ} \mathrm{C}$ [67]. At the same temperature and $\mathrm{C} / 10$ rate, $\mathrm{LiFePO}_{4} / \mathrm{Li}$ battery employing this electrolyte delivered the first discharge capacity of $138 \mathrm{mAh} \mathrm{g}^{-1}$ which was sustainable even after the 20th cycle $\left(138 \mathrm{mAh} \mathrm{g}^{-1}\right)$ [67]. The SPE has also been tested in Li-sulfur battery under similar conditions and acquired the capacity of $175 \mathrm{mAh} \mathrm{g}^{-1}$ after the 50th cycle, with an initial capacity of $375 \mathrm{mAh} \mathrm{g}^{-1}$ [67]. After cycling, there was no lithium dendrite formation, as evidenced through SEM micrograph. In addition to inhibit crystallinity percentage, the crosslinked electrolyte is said to have the ability to hamper lithium dendrite growth when being used in Li-ion cells and to improve dimensional stability at elevated temperatures [66-69].

In a separate report, PEO underwent crosslinking reaction with tetraethylene glycol dimethyl ether (TEGDME) employing 4-methyl benzophenone (MBP) as crosslinker agent, LiTFSI salt under UV radiation without solvent usage [68]. It is said that MBP can remove $\mathrm{H}^{+}$from its methylene group via hydrogen abstraction to form free-radical chains [68]. Likewise, TEGDME that contained the methylene group produced free radicals. These freeradical chains have interlinked with -EO- unit of PEO chain under UV exposure to form SPE film that displayed features, such as being highly amorphous and having a uniform morphology, high mechanical strength, good flexibility, low $T_{g}$ of $-34^{\circ} \mathrm{C}$ and compatibility with Li metal electrode. At $25^{\circ} \mathrm{C}$, the SPE showed a conductivity of $0.11 \times 10^{-3} \mathrm{~S} \mathrm{~cm}^{-1}, t_{\mathrm{Li}}$ of 0.55 and diffusion coefficient of $\mathrm{Li}^{+}$ion of $5.6 \times 10^{-6} \mathrm{~cm}^{2} \mathrm{~s}^{-1}$ [68]. The $\mathrm{TiO}_{2} / \mathrm{Li}$ cell having such an electrolyte had good cyclability over 100 cycles, with a capacity of $\sim 138 \mathrm{mAh} \mathrm{g}^{-1}$ and almost 90\% capacity retention [68]. Lim et al. [70] employed an in situ polymerization procedure to prepare SPE based on crosslinking poly(ethylene glycol) diglycidyl ether (PEGDE) and bisphenol A diglycidyl ether (BADGE) with 1-ethyl-3-methylimidazolium bis(trifluoromethylsulfonyl)imide (EMIMTFSI), using PEI as crosslinker without solvent. The SPE was prepared directly on activated carbon electrode for supercapacitor application before the curing process. Such an SPE film showed a conductivity of $2.41 \times 10^{-3} \mathrm{~S} \mathrm{~cm}^{-1}$ at $25^{\circ} \mathrm{C}$ and capacitance value of $19.8 \mathrm{~F} \mathrm{~g}^{-1}$ at $2 \mathrm{mV} \mathrm{s}^{-1}$ scan rate with decent cyclability upon 10,000 cycles [70].

Chitosan in 1\% acetic acid solution was subjected to a crosslinking process with methanesulfonic acid (MSA) and dodecylbenzene sulfonic acid sodium salt (DBSA-Na), using sulfuric acid as an agent to form chitosan-MSA and chitosan-DBSA membranes, respectively [71]. Such an action improved the proton conductivity and the thermal and mechanical stabilities of the chitosan-based membranes, which can be applied as solid 
electrolyte membranes in PEMFCs. At the elevated temperature of $90{ }^{\circ} \mathrm{C}$, the proton conductivity was $3.09 \times 10^{-4} \mathrm{~S} \mathrm{~cm}^{-1}$ for chitosan-DBSA film, whereas $2.18 \times 10^{-4} \mathrm{~S} \mathrm{~cm}^{-1}$ was the conductivity exhibited by the chitosan-MSA membrane [71]. The non-crosslinked chitosan membrane was also prepared for comparison and showed lowest conductivity of $1.04 \times 10^{-4} \mathrm{~S} \mathrm{~cm}^{-1}$ at same temperature [71]. The grafted copolymers consisting of natural rubber and methyl methacrylate, namely 49\% PMMA-grafted NR (MG49) [48,72,73] and $30 \%$ PMMA-grafted NR (MG30) [74], have been used as polymer hosts to produce polymer electrolytes. Su'ait et al. [72] reported a conductivity of $1.00 \times 10^{-12} \mathrm{~S} \mathrm{~cm}^{-1}$ for pure MG49 at $30^{\circ} \mathrm{C}$, and this value increased to $2.30 \times 10^{-7} \mathrm{~S} \mathrm{~cm}^{-1}$ when MG49 was incorporated with $20 \mathrm{wt} . \% \mathrm{LiBF}_{4}$ salt. Such an electrolyte of $\mathrm{MG} 49-\mathrm{LiBF}_{4}$ was then added to another salt (LiI and $\mathrm{LiCF}_{3} \mathrm{SO}_{3}$ ) by the same group of researchers for the mixed-salt effect [48]. It was found that the ambient conductivity increased with different salts and combination of salts as follows: $\mathrm{LiCF}_{3} \mathrm{SO}_{3}\left(2.15 \times 10^{-11} \mathrm{~S} \mathrm{~cm}^{-1}\right)<\mathrm{LiI}\left(4.73 \times 10^{-9} \mathrm{~S} \mathrm{~cm}^{-1}\right)<\mathrm{LiCF}_{3} \mathrm{SO}_{3}+\mathrm{LiBF}_{4}$ $\left(7.71 \times 10^{-9} \mathrm{~S} \mathrm{~cm}^{-1}\right)<\operatorname{LiBF}_{4}\left(1.42 \times 10^{-8} \mathrm{~S} \mathrm{~cm}^{-1}\right)<\operatorname{LiBF}_{4}+\operatorname{LiI}\left(1.89 \times 10^{-6} \mathrm{~S} \mathrm{~cm}^{-1}\right)$ [48]. This clearly demonstrates that the ionic conductivity was enhanced significantly for the MG49-based SPE having double salts of $\mathrm{LiBF}_{4}$ and LiI at a ratio of 30:70, while the addition of $\mathrm{LiCF}_{3} \mathrm{SO}_{3}$ into the MG49- $\mathrm{LiBF}_{4}$ electrolyte had an adverse effect on the conductivity. The transference number of ions for the five samples was observed to increase in the same order of conductivity [48]. It can be understood that the degree of crystallinity increased in the reverse order [48]. Modified natural rubber has superior elastic features for better interfacial contact between electrolyte and electrode when applied in electrochemical devices. Another strategy to improve the properties of electrolyte is to bind the anion directly to the polymer chain to form a single-ion-conducting polymer electrolyte. Such an electrolyte consisting of poly[lithium 1-[3-(methacryloyloxy) propylsulfonyl]-1-(trifluoromethylsulfonyl) imide] (PLiMTFSI) attached to PEG-crosslinked poly(2-hydroxyethylacrylate) (PHEA) showed improved mechanical strength as compared to an electrolyte of crosslinked PEG-PHEA doped with LiTFSI, even though its conductivity is lower than the latter [75]. Nonetheless, the single-ion-conducting polymer electrolyte could minimize lithium dendrite formation and gave better results in Li-ion cells.

\subsubsection{Treatment of SPEs}

The polymer electrolytes can also be subjected to radiation in order to tune their properties in terms of structural, thermal, electrical and mechanical aspects. Various radiation sources, including gamma rays, $\mathrm{X}$-rays, ultraviolet rays, electron, neutron and ion beams, can be employed. Solution-cast-prepared SPE based on PEO with lithium sulfate $\left(\mathrm{Li}_{2} \mathrm{SO}_{4}\right)$ salt has been irradiated with low-energy electron beams of $8 \mathrm{MeV}$ by Raghu et al. [76]. At $30^{\circ} \mathrm{C}$, the conductivity was enhanced to the order of $10^{-4} \mathrm{~S} \mathrm{~cm}^{-1}$ for PEO$\mathrm{Li}_{2} \mathrm{SO}_{4}$ electrolyte after exposure to $30 \mathrm{kGy}$ dose of electron beam from $10^{-5} \mathrm{~S} \mathrm{~cm}^{-1}$ for non-irradiated electrolyte. Analyses from DSC and X-ray diffraction (XRD) demonstrated that the former have a lower melting temperature $\left(67.6^{\circ} \mathrm{C}\right)$ and are more amorphous in nature, with reduced crystallinity, than the latter $\left(69.4^{\circ} \mathrm{C}\right.$ melting temperature and more crystalline), while FTIR results indicated that the polymer chain was disrupted and degraded after irradiation [76]. Irradiating of $\mathrm{Li}^{3+}$ ion at high energy of $60 \mathrm{MeV}$ on two different electrolytes of PEO-NaI and PVP-NaI showed increment in conductivity as compared to unirradiated electrolyte films [77]. Besides conductivity, higher values for number of mobile ions, ionic mobility and dielectric constant have been reported for the solution-cast-prepared SPE after ion-beam irradiation [77]. PAN-based SPE having LiBOB salt also exhibited enhancement in conductivity and transport properties $(n, \mu$ and $D)$ after being radiated with a gamma-ray dose of $15 \mathrm{kGy}$ [78]. Ambient conductivity was increased by 58.6 times from $1.74 \times 10^{-6} \mathrm{~S} \mathrm{~cm}^{-1}$ to $1.02 \times 10^{-4} \mathrm{~S} \mathrm{~cm}^{-1}$, while improvement of 12.2, 4.8 and $\sim 4.7$ times was obtained in $n, \mu$ and $D$, respectively [78]. Likewise, PVDFLiBOB SPE has attained higher values of conductivity and ionic transport upon gamma-ray radiation as compared to non-irradiated electrolyte [79]. Hema et al. [80] also reported similar observation in PVA-PVDF- $\mathrm{LiCF}_{3} \mathrm{SO}_{3}-\mathrm{SiO}_{2} \mathrm{SPEs}$, where conductivity was boosted 
to $9.40 \times 10^{-4} \mathrm{~S} \mathrm{~cm}^{-1}$ at $30{ }^{\circ} \mathrm{C}$ after gamma-ray exposure (15 Gy dose). The conductivity of such an electrolyte without radiation treatment was $1.70 \times 10^{-4} \mathrm{~S} \mathrm{~cm}^{-1}$. Ionic transference number for the irradiated SPE also showed increment $\left(t_{i o n}=0.99\right)$ as compared to that of non-gamma ray treated SPE $\left(t_{i o n}=0.98\right)$ [80]. On the other hand, lower values for the percentage of crystallinity, $T_{g}$ and melting point were detected in the former than in the latter [80]. In general, it is to be noted that conductivity enhancement has been observed at optimized dosage of radiation irrespective of the sources due to polymer chain scission, whereas too much radiation dose will be detrimental to the properties of SPE, and this is attributed to crosslinking and increase in crystallinity.

In another work of Raghu et al. [81], a comparison was made between gammaray (cobalt-60 source) and electron-beam (energy of $8 \mathrm{MeV}$ ) treatments on PEO-based SPEs of cadmium chloride $\left(\mathrm{CdCl}_{2}\right)$ salt. Non-irradiated electrolyte exhibited the lowest conductivity value at $8.63 \times 10^{-6} \mathrm{~S} \mathrm{~cm}^{-1}$ at $30{ }^{\circ} \mathrm{C}$, as compared to gamma-ray-treated $\left(0.115 \mathrm{~S} \mathrm{~cm}^{-1}\right)$ and electron-beam-irradiated $\left(0.175 \mathrm{~S} \mathrm{~cm}^{-1}\right)$ electrolytes. Micrographs from scanning electron microscopy (SEM) showed less PEO spherulites in both irradiated SPEs as compared to that of non-irradiated SPE, indicating that a more amorphous region existed in the former case. In addition, the SEM image for electrolyte after electron-beam exposure displayed a homogenous morphology, while the formation of aggregates was seen in the micrograph of SPE irradiated with gamma radiation [81]. The SPEs were irradiated with electron beam and gamma ray separately at two different doses (50 and $150 \mathrm{kGy}$ ), and it was found that, at the $150 \mathrm{kGy}$ dosage, both types of radiation gave a higher conductivity (of the order of $10^{-4} \mathrm{~S} \mathrm{~cm}^{-1}$ ) than that irradiated at the $50 \mathrm{kGy}$ dose (around $10^{-5} \mathrm{~S} \mathrm{~cm}^{-1}$ ) [81]. The authors have concluded that the electron-beam treatment is an effective approach as compared to gamma-ray radiation in making the SPE more conducting due to reduction in crystallinity. Recent work illustrated contradictory results, wherein no effect was observed on the conductivity upon neutron irradiation at varied dosages (15 to $47 \mathrm{kGy}$ ) on PVDFLiBOB SPEs prepared via solution-casting route [82]. Ambient conductivity was the highest at $1.27 \times 10^{-5} \mathrm{~S} \mathrm{~cm}^{-1}$ for the non-irradiated SPE as compared to similar electrolyte after exposed to neutron radiation with lowest value at $4.30 \times 10^{-7} \mathrm{~S} \mathrm{~cm}^{-1}$ for SPE subjected to $47 \mathrm{kGy}$ dose [82]. This was attributed to decrement in $\mu$ and $D$, as well as higher degree of crystallinity. The authors have deduced that an improvement in mechanical integrity in the electrolyte has occurred after being irradiated with a neutron [82]. Sinha et al. [83] have observed that there was a slight decrement in conductivity at ambient temperature for the solution-cast-prepared SPE based on PEO with ammonium perchlorate $\left(\mathrm{NH}_{4} \mathrm{ClO}_{4}\right)$ salt after being irradiated with gamma rays, followed by minor conductivity increment at $50{ }^{\circ} \mathrm{C}$. In the following sections, additional ingredients such as secondary polymer, plasticizers, fillers and other additives that have been integrated into various SPEs are discussed.

\subsubsection{Blended Solid Polymer Electrolytes}

Polymer blending can be regarded as the most convenient and simplest way to prepare SPEs that are highly conducting, flexible and thermally stable and that have good mechanical strength without additional employment of materials such as initiator, linker agent, radiation sources, etc., thus indirectly making this approach more cost-effective as compared to other techniques aforementioned. In this technique, two or more polymers which are miscible in the appropriate solvent form a homogenous solution before addition of the conducting salt. The blending of polymer approach is able to (i) reduce the glass transition temperature, (ii) decrease the degree of crystallinity, (iii) increase the ionic conductivity, (iv) improve the thermal stability, (v) enhance the mechanical strength and (vi) boost the performance of electrochemical devices. There are many studies on blended SPEs available in the literature. Table 5 lists some of the systems under this category. 
Table 5. Various blended SPEs systems, along with their conductivity values and other important parameters.

\begin{tabular}{|c|c|c|c|c|}
\hline Electrolyte System & $\begin{array}{l}\text { Preparation } \\
\text { Method }\end{array}$ & $\begin{array}{l}\text { Conductivity, } \sigma \\
\qquad\left(\mathrm{S} \mathrm{cm}^{-1}\right)\end{array}$ & Important Findings & Reference \\
\hline $\begin{array}{l}\text { PVA:PVP (70:30)-25 } \\
\text { wt. } \% \mathrm{LiNO}_{3}\end{array}$ & Solution casting & $6.83 \times 10^{-4}$ & $\begin{array}{c}E_{A}=0.27 \mathrm{eV} ; T_{g}=80^{\circ} \mathrm{C} \\
70 \text { PVA:30 PVP film: } \\
\sigma=1.58 \times 10^{-6} \mathrm{~S} \mathrm{~cm}^{-1} ; T_{g}=130^{\circ} \mathrm{C} \\
\text { Degree of swelling lower than } \\
\text { blend SPE }\end{array}$ & [84] \\
\hline $\begin{array}{l}\text { Chitosan:PVA } \\
(1: 1)-\mathrm{NH}_{4} \mathrm{I}\end{array}$ & Solution casting & $1.77 \times 10^{-6}\left(30^{\circ} \mathrm{C}\right)$ & $\begin{array}{c}E_{A}=0.38 \mathrm{eV} \\
\text { Without PVA blend: } \\
\sigma=3.73 \times 10^{-7} \mathrm{~S} \mathrm{~cm}^{-1}\left(30^{\circ} \mathrm{C}\right) \\
E_{A}=0.46 \mathrm{eV}\end{array}$ & [85] \\
\hline $\begin{array}{l}\text { Chitosan:PEO } \\
(1: 1)-\mathrm{NH}_{4} \mathrm{I}\end{array}$ & Solution casting & $3.66 \times 10^{-6}\left(30^{\circ} \mathrm{C}\right)$ & 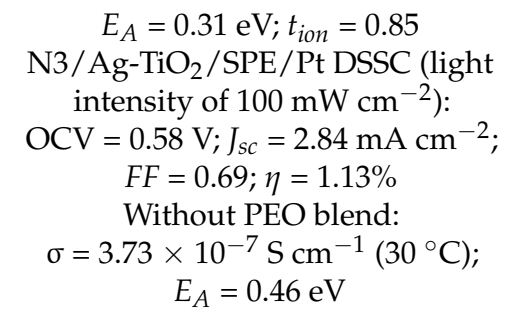 & [86] \\
\hline $\begin{array}{l}\text { PEMA:PVDF-HFP } \\
(70: 30)-\mathrm{LiCF}_{3} \mathrm{SO}_{3}\end{array}$ & $\begin{array}{l}\text { Reflux }+ \text { Solution } \\
\text { casting }\end{array}$ & $2.87 \times 10^{-7}(\mathrm{RT})$ & $\begin{array}{c}\text { PEMA- } \mathrm{LiCF}_{3} \mathrm{SO}_{3}: \\
\sigma=9.18 \times 10^{-8} \mathrm{~S} \mathrm{~cm}^{-1}(\mathrm{RT})\end{array}$ & [87] \\
\hline $\begin{array}{l}50 \%(\text { PEO+LiTFSI }): 50 \% \\
\text { PPC }[\mathrm{EO}] /[\mathrm{Li}]=18: 1\end{array}$ & Solution casting & $\begin{array}{l}2.04 \times 10^{-5}\left(25^{\circ} \mathrm{C}\right) \\
2.82 \times 10^{-4}\left(60^{\circ} \mathrm{C}\right)\end{array}$ & 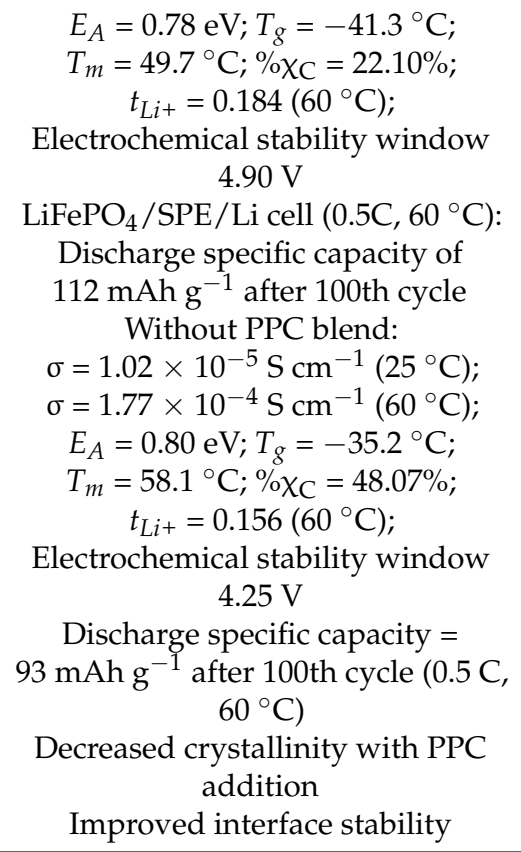 & [88] \\
\hline $\begin{array}{l}\text { PEO:PVP (9:1)-8 wt.\% } \\
\qquad \mathrm{LiClO}_{4}\end{array}$ & Solution casting & $0.23 \times 10^{-5}\left(30^{\circ} \mathrm{C}\right)$ & $\begin{array}{c}\text { Bandgap energy }=4.07 \mathrm{eV} \text { (indirect) } \\
\text { and } 4.35 \mathrm{eV} \text { (direct) } \\
\text { Thermally stable till } 324{ }^{\circ} \mathrm{C} \\
\text { Lowest intensity in } \\
\text { photoluminescence results } \\
\text { compared to that at other PEO:PVP } \\
\text { ratios }\end{array}$ & {$[89,90]$} \\
\hline
\end{tabular}


Table 5. Cont.

\begin{tabular}{|c|c|c|c|c|}
\hline Electrolyte System & $\begin{array}{l}\text { Preparation } \\
\text { Method }\end{array}$ & $\begin{array}{l}\text { Conductivity, } \sigma \\
\left(\mathrm{S} \mathrm{cm}^{-1}\right)\end{array}$ & Important Findings & Reference \\
\hline $\begin{array}{l}\text { CMC:PVA: } \mathrm{NH}_{4} \mathrm{NO}_{3} \\
\text { (56:14:30 wt. } \%)\end{array}$ & Solution casting & $1.70 \times 10^{-3}$ & $\begin{array}{c}T_{g}=88.7^{\circ} \mathrm{C} ; t_{\mathrm{H}+}=0.42 \\
\text { Decomposition temperature }= \\
340{ }^{\circ} \mathrm{C}\end{array}$ & [91] \\
\hline $\begin{array}{c}\text { MG49:PMMA } \\
(70: 30)-25 \text { wt. } \% \mathrm{LiBF}_{4} \\
{[\mathrm{O}] /[\mathrm{Li}]=5: 1}\end{array}$ & Solution casting & $8.60 \times 10^{-6}\left(30^{\circ} \mathrm{C}\right)$ & $\begin{array}{c}\text { MG49-PMMA film: } \\
\sigma=1.10 \times 10^{-12} \mathrm{~S} \mathrm{~cm}^{-1}\left(30^{\circ} \mathrm{C}\right)\end{array}$ & [73] \\
\hline $\begin{array}{c}\text { MG49:PMMA } \\
(70: 30)-25 \text { wt. } \% \mathrm{LiClO}_{4} \\
{[\mathrm{O}] /[\mathrm{Li}]=6: 1}\end{array}$ & Solution casting & $1.50 \times 10^{-8}\left(30^{\circ} \mathrm{C}\right)$ & $\begin{array}{c}\text { MG49-PMMA film: } \\
\sigma=1.10 \times 10^{-12} \mathrm{~S} \mathrm{~cm}^{-1}\left(30^{\circ} \mathrm{C}\right)\end{array}$ & [73] \\
\hline CMKC:CMC (60:40)-LiI & Solution casting & $3.89 \times 10^{-3}\left(27^{\circ} \mathrm{C}\right)$ & $\begin{array}{c}\mathrm{T}_{g}=-43.0^{\circ} \mathrm{C} \\
\mathrm{N} 719 / \mathrm{TiO}_{2} / \mathrm{SPE} / \mathrm{Pt} \mathrm{DSSC} \text { (light } \\
\left.\text { intensity of } 100 \mathrm{~mW} \mathrm{~cm} \mathrm{~m}^{-2}\right): \\
\mathrm{OCV}=0.492 \mathrm{~V} ; J_{s c}=0.40 \mathrm{~mA} \mathrm{~cm}{ }^{-2} \\
F F=0.57 ; \eta=0.11 \%\end{array}$ & [92] \\
\hline HCh:PVC (90:10)-NaI & Solution casting & $1.50 \times 10^{-5}(\mathrm{RT})$ & 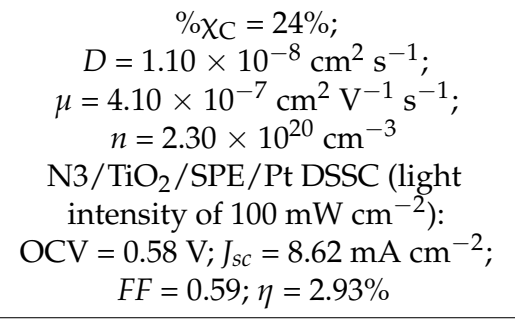 & [93] \\
\hline $\begin{array}{l}\text { PEO:WPU (3:1)-LiTFSI } \\
\text { [EO]/[Li] = 16:1 }\end{array}$ & Solution casting & $3.10 \times 10^{-3}\left(80^{\circ} \mathrm{C}\right)$ & $\begin{array}{c}T_{g}=-45.4{ }^{\circ} \mathrm{C} \text {; thermally stable till } \\
300{ }^{\circ} \mathrm{C} \\
\mathrm{LiFePO}_{4} / \mathrm{SPE} / \mathrm{Li} \text { battery: } \\
\text { Discharge capacity }=122 \mathrm{mAh} \mathrm{g}^{-1} \\
\text { after } 100 \text { th cycle }\left(1 \mathrm{C}, 80{ }^{\circ} \mathrm{C}\right), 96 \% \\
\text { capacity retention }\end{array}$ & [94] \\
\hline $\begin{array}{l}\text { PEO:TPU (3:1)-LiTFSI } \\
\text { [EO]/[Li] }=16: 1\end{array}$ & Solution casting & $5.30 \times 10^{-4}\left(60^{\circ} \mathrm{C}\right)$ & $\begin{array}{c}t_{\mathrm{Li+}}=0.31 ; \text { Tensile stress } 1.38 \mathrm{MPa} \\
\mathrm{LiFePO}_{4} / \mathrm{SPE} / \mathrm{Li} \text { battery: } \\
\text { Discharge capacity }=112 \mathrm{mAh} \mathrm{g}^{-1} \\
\text { after } 100 \text { th cycle }\left(1 \mathrm{C}, 60^{\circ} \mathrm{C}\right), 96 \% \\
\text { capacity retention }\end{array}$ & [95] \\
\hline $\begin{array}{l}\text { PEO-PVP-NaIO } \\
(65: 25: 10 \text { wt. } \%)\end{array}$ & Solution casting & $1.56 \times 10^{-7}\left(30^{\circ} \mathrm{C}\right)$ & $\begin{array}{c}E_{A}=0.22 \mathrm{eV} ; T_{g}=50.2^{\circ} \mathrm{C} \\
\% \chi_{C}=55.0 \% \\
\mathrm{D}=2.72 \times 10^{-8} \mathrm{~cm}^{2} \mathrm{~s}^{-1} \\
\mu=1.0 \times 10^{-4} \mathrm{~cm}^{2} \mathrm{~V}^{-1} \mathrm{~s}^{-1} \\
n=9.35 \times 10^{15} \mathrm{~cm}^{-3} \\
\text { Direct optical bandgap }=3.60 \mathrm{eV} \\
\text { Refractive index }=2.28\end{array}$ & [96] \\
\hline $\begin{array}{c}\text { PEO:PVP } \\
(4: 1)-\mathrm{Mg}\left(\mathrm{NO}_{3}\right)_{2}\end{array}$ & Solution casting & $5.80 \times 10^{-4}\left(25^{\circ} \mathrm{C}\right)$ & $\begin{array}{c}E_{A}=0.31 \mathrm{eV} ; t_{+}=0.33 \\
\text { Thermally stable till } 220^{\circ} \mathrm{C} \\
\mathrm{MgMn}_{2} \mathrm{O}_{4} / \mathrm{SPE} / \mathrm{Mg} \text { battery: } \\
\mathrm{OCV}=1.46 \mathrm{~V}\end{array}$ & [97] \\
\hline
\end{tabular}


Table 5. Cont.

\begin{tabular}{|c|c|c|c|c|}
\hline Electrolyte System & $\begin{array}{l}\text { Preparation } \\
\text { Method }\end{array}$ & $\begin{array}{l}\text { Conductivity, } \sigma \\
\left(\mathrm{S} \mathrm{cm}^{-1}\right)\end{array}$ & Important Findings & Reference \\
\hline $\begin{array}{l}\text { PVDF-HFP:PEO } \\
(4: 1)-K I-T B A I-I_{2}\end{array}$ & Solution casting & $4.53 \times 10^{-5}\left(25^{\circ} \mathrm{C}\right)$ & $\begin{array}{c}T_{m}=144.9^{\circ} \mathrm{C} ; \% \chi_{C}=18.1 \% \\
\mathrm{~N} 3 / \mathrm{TiO}_{2} / \mathrm{SPE} / \mathrm{Pt} \mathrm{DSSC}(\text { light } \\
\left.\text { intensity of } 60 \mathrm{~mW} \mathrm{~cm}^{-2}\right): \\
\mathrm{OCV}=0.674 \mathrm{~V} ; J_{s c}=4.39 \mathrm{~mA} \mathrm{~cm}^{-2} ; \\
F F=0.50 ; \eta=2.46 \% \\
\text { Without } \mathrm{PEO} \text { blend: } \\
\sigma=9.99 \times 10^{-6} \mathrm{~S} \mathrm{~cm}^{-1}\left(25^{\circ} \mathrm{C}\right) \\
T_{m}=146.5^{\circ} \mathrm{C} ; \% \mathrm{XC}_{\mathrm{C}}=23.5^{\circ} \% \\
\mathrm{OCV}=0.648 \mathrm{~V} ; J_{s c}=3.78 \mathrm{~mA} \mathrm{~cm}{ }^{-2} ; \\
F F=0.46 ; \eta=1.88 \%\end{array}$ & [98] \\
\hline $\begin{array}{l}\text { PVAc:PMMA } \\
\text { (70:30)-LiCl }\end{array}$ & Solution casting & $1.03 \times 10^{-5}\left(30^{\circ} \mathrm{C}\right)$ & $\begin{array}{c}E_{A}=0.25 \mathrm{eV} ; T_{g}=42.6^{\circ} \mathrm{C} ; t_{+}=0.97 \\
D_{+}=6.93 \times 10^{-11} \mathrm{~cm}^{2} \mathrm{~s}^{-1} \\
\mu=2.65 \times 10^{-9} \mathrm{~cm}^{2} \mathrm{~V}^{-1} \mathrm{~s}^{-1} \\
n=2.35 \times 10^{22} \mathrm{~cm}^{-3}\end{array}$ & [99] \\
\hline
\end{tabular}

PVP—poly(vinyl pyrrolidone); $\mathrm{LiNO}_{3}$ —lithium nitrate; PPC—propylene carbonate; CMKC—carboxymethyl K-carrageenan; N719— di-tetrabutylammonium cis-bis(isothiocyanato)bis(2,2'-bipyridyl-4,4'-dicarboxylato) ruthenium(II); PVC—poly(vinyl chloride); WPU— waterborne polyurethane; TPU—-thermoplastic polyurethane; $\mathrm{NaIO}_{4}$ - sodium periodate; $\mathrm{Mg}\left(\mathrm{NO}_{3}\right)_{2}$ - magnesium nitrate; TBAItetrabutylammonium iodide; PVAc—-poly(vinyl acetate); $\mathrm{LiCl}$-lithium chloride.

Sengwa et al. [100] have investigated the effect of SPE preparation method on conductivity. The SPE comprising PEO blended with PMMA at a ratio of $1: 1$ and $\mathrm{LiCF}_{3} \mathrm{SO}_{3}$ salt has been prepared in four ways: (i) conventional solution cast coupled with hot melt-pressing; (ii) ultrasonication followed by solution casting and hot melt press; (iii) irradiation of microwave before solution-cast and hot-melt-press techniques; and (iv) ultrasonication followed by microwave exposure, solution casting and hot melt press. The authors have observed that conductivity decrement of the similar SPE in the following order: $\sigma_{\text {(route iii) }}$ $\left(1.99 \times 10^{-6} \mathrm{~S} \mathrm{~cm}^{-1}\right)>\sigma_{\text {(route iv) }}\left(1.56 \times 10^{-6} \mathrm{~S} \mathrm{~cm}^{-1}\right)>\sigma_{\text {(route i) }}\left(1.36 \times 10^{-6} \mathrm{~S} \mathrm{~cm}^{-1}\right)$ $>\sigma_{\text {(route ii) }}\left(0.11 \times 10^{-6} \mathrm{~S} \mathrm{~cm}^{-1}\right)$ [100]. They have speculated that the electrolyte made from microwave-assisted solution-cast/hot-melt-press procedure has produced more of a pathway for ionic conduction as compared to other methods [100]. Another unrelated work has compared the usefulness of the blending approach with grafting technique on $\mathrm{LiClO}_{4}$ containing SPE system with sulfonated polyether ether ketone (SPEEK) and polyethylene glycol (PEG) as polymer hosts [101]. The SPEEK grafted with PEG electrolyte gave higher conductivity (around $10^{-5} \mathrm{~S} \mathrm{~cm}^{-1}$ ) when compared to SPEEK-PEG blended electrolyte $\left(10^{-6} \mathrm{~S} \mathrm{~cm}^{-1}\right)$ at $30^{\circ} \mathrm{C}$, thus implying the grafting method can suppress PEG crystallinity more than the blending technique [101].

Liu and co-workers [102] have combined both chemical (crosslinking) and physical (blending) routes together, i.e., crosslinked (3-glycidyloxypropyl)trimethoxysilane (GLYMO) with polyetheramine and also crosslinked poly(ethylene glycol) diglycidyl ether (PEGDGE) with polyetherdiamine before blending their products at 70:30 ratio in THF solvent and added with $\mathrm{LiClO}_{4}$ salt. The $[\mathrm{EO}] /[\mathrm{Li}]$ ratio was optimized at 16:1. Such a unique SPE exhibited the conductivities of $1.20 \times 10^{-4} \mathrm{~S} \mathrm{~cm}^{-1}$ and $8.30 \times 10^{-4} \mathrm{~S} \mathrm{~cm}^{-1}$ at 30 and $80{ }^{\circ} \mathrm{C}$, respectively [102]. The $T_{g}$ value was $-43.6^{\circ} \mathrm{C}$, and the transference number of $\mathrm{Li}^{+}$ions was 0.28 at $70^{\circ} \mathrm{C}$. This electrolyte was thermally stable up to $260^{\circ} \mathrm{C}$ and gave the capacities of $110 \mathrm{mAh} \mathrm{g}^{-1}$ (The first cycle) and $61 \mathrm{mAh} \mathrm{g}^{-1}$ (100th cycle) when applied in $\mathrm{LiFePO}_{4} / \mathrm{Li}$ battery at $0.2 \mathrm{C}$ rate [102]. As a summary, blended SPEs show superior properties than SPEs containing single polymer matrix.

\subsubsection{Plasticized Solid Polymer Electrolytes}

The main idea of plasticized polymer electrolyte is to improve the elasticity by lowering the $T_{g}$. As stated in the previous section and Equation (3), the segmental movement of the polymer backbone contributes to the conductivity of SPEs. Increasing the segmental 
motion will improve the ionic conductivity and can be easily achieved by adding plasticizers into the polymer matrix. There are many types of plasticizers such as EC, PC, PEG, DMSO, diethyl carbonate (DEC), dimethyl carbonate (DMC), glycerol, gBL and DMF to name a few that affect the ionic conductivity of SPEs in different ways. Note that EC, PC, DMSO, gBL and DMF can also serve as a solvent, as listed in Table 3, while PEG of low molecular weight $\left(\mathrm{M}_{\mathrm{W}}\right)$ is usually used as a plasticizing agent. Plasticizers with high a dielectric constant, e.g., EC, as mentioned in the previous section, helps in salt dissociation, lowering the formation of ion pairs and ion aggregates leading to conductivity enhancement. Besides high dielectric constant, a good plasticizer should possess low viscosity to increase the mobility of ions. Furthermore, the incorporation of plasticizer in an electrolyte offers additional passage for ion transport. Some plasticized polymer electrolytes in the solid form that have been studied are tabulated in Table 6 .

Table 6. Examples of plasticized SPEs systems found in the literature.

\begin{tabular}{|c|c|c|c|c|}
\hline Electrolyte System & $\begin{array}{l}\text { Preparation } \\
\text { Method }\end{array}$ & $\begin{array}{l}\text { Conductivity, } \sigma \\
\left(\mathrm{S} \mathrm{cm}^{-1}\right)\end{array}$ & Important Findings & Reference \\
\hline PEO-LiPF 6 -EC & Solution casting & $2.06 \times 10^{-4}\left(25^{\circ} \mathrm{C}\right)$ & $\begin{array}{c}\text { Bandgap energy }=5.63 \mathrm{eV} \text { (indirect) } \\
\text { and } 5.80 \mathrm{eV} \text { (direct) } \\
\text { Unplasticized SPE: } \\
\sigma=4.10 \times 10^{-5} \mathrm{~S} \mathrm{~cm}^{-1}\left(25^{\circ} \mathrm{C}\right) \\
\text { Bandgap energy }=5.74 \mathrm{eV} \text { (indirect) } \\
\text { and } 5.90 \mathrm{eV} \text { (direct) }\end{array}$ & [103] \\
\hline PGMA-LiClO 4 -EC & Solution casting & $2.00 \times 10^{-4}(\mathrm{RT})$ & $\begin{array}{c}\text { PGMA was synthesized via } \\
\text { photo-polymerization route. } \\
E_{A}=0.21 \mathrm{eV} \\
\text { Electrochemical stability window } \\
3.00 \mathrm{~V} \\
\text { Unplasticized SPE: } \\
\sigma=4.20 \times 10^{-5} \mathrm{~S} \mathrm{~cm}^{-1}(\mathrm{RT}) \\
E_{A}=0.26 \mathrm{eV} \\
\text { Electrochemical stability window } \\
2.50 \mathrm{~V}\end{array}$ & [104] \\
\hline $\mathrm{PEO}^{-\mathrm{LiClO}_{4}-\mathrm{SN}}$ & Solution casting & $\sim 9.12 \times 10^{-5}\left(20^{\circ} \mathrm{C}\right)$ & $\begin{array}{c}E_{A}=0.45 \mathrm{eV} \\
\text { Unplasticized SPE: } \\
\sigma=3.79 \times 10^{-7} \mathrm{~S} \mathrm{~cm}^{-1}\left(20{ }^{\circ} \mathrm{C}\right) \\
E_{A}=0.89 \mathrm{eV}\end{array}$ & [105] \\
\hline $\begin{array}{l}\mathrm{HEC}-\mathrm{LiCF}_{3} \mathrm{SO}_{3}- \\
\text { glycerol } \\
{[\mathrm{EO}] /[\mathrm{Li}]=6: 1}\end{array}$ & Solution casting & $1.06 \times 10^{-5}\left(30^{\circ} \mathrm{C}\right)$ & $E_{A}=0.18 \mathrm{eV} ; T_{g}=-83{ }^{\circ} \mathrm{C}$ & [106] \\
\hline $\begin{array}{l}\text { Chitosan- } \mathrm{LiClO}_{4}- \\
\text { glycerol }\end{array}$ & Solution casting & $\sim 3.00 \times 10^{-5}\left(25^{\circ} \mathrm{C}\right)$ & $\begin{array}{c}\text { Too much glycerol, SPE easily } \\
\text { torn off. } \\
\text { Without glycerol: } \\
\sigma=1.40 \times 10^{-5} \mathrm{~S} \mathrm{~cm}^{-1}\left(25^{\circ} \mathrm{C}\right)\end{array}$ & [107] \\
\hline $\begin{array}{l}\text { Chitosan- } \mathrm{LiClO}_{4} \text { - } \\
\text { glycerol }\end{array}$ & Solution casting & $1.20 \times 10^{-3}\left(25^{\circ} \mathrm{C}\right)$ & $\begin{array}{c}t_{\text {ion }}=0.955 \\
D=4.19 \times 10^{-9} \mathrm{~cm}^{2} \mathrm{~s}^{-1} \\
\mu=1.63 \times 10^{-7} \mathrm{~cm}^{2} \mathrm{~V}^{-1} \mathrm{~s}^{-1} \\
n=4.57 \times 10^{22} \mathrm{~cm}^{-3} \\
\text { Specific capacitance }=98.99 \mathrm{~F} \mathrm{~g}^{-1} \text { at } \\
\text { scan rate } 10 \mathrm{mV} \mathrm{s}^{-1}\end{array}$ & [108] \\
\hline $\mathrm{PVB}-\mathrm{LiClO}_{4}-\mathrm{PEG}_{400}$ & Solution casting & $2.15 \times 10^{-6}(\mathrm{RT})$ & $\begin{array}{c}\text { Unplasticized SPE: } \\
\sigma=5.80 \times 10^{-10} \mathrm{~S} \mathrm{~cm}^{-1}\end{array}$ & [109] \\
\hline
\end{tabular}


Table 6. Cont.

\begin{tabular}{|c|c|c|c|c|}
\hline Electrolyte System & $\begin{array}{l}\text { Preparation } \\
\text { Method }\end{array}$ & $\begin{array}{l}\text { Conductivity, } \sigma \\
\left(\mathrm{S} \mathrm{cm}^{-1}\right)\end{array}$ & Important Findings & Reference \\
\hline $\mathrm{PEMA}^{-\mathrm{NH}_{4} \mathrm{I}-\mathrm{EC}}$ & Solution casting & $1.16 \times 10^{-5}(\mathrm{RT})$ & $\begin{array}{c}t_{\text {ion }}=0.85 \\
n=1.75 \times 10^{21} \mathrm{~m}^{-3}\end{array}$ & [110] \\
\hline $\begin{array}{c}\mathrm{PEMA}^{-\mathrm{NH}_{4} \mathrm{CF}_{3} \mathrm{SO}_{3}-} \\
\text { BMATSFI }\end{array}$ & Solution casting & $8.35 \times 10^{-4}\left(30^{\circ} \mathrm{C}\right)$ & $\begin{array}{c}T_{g}=2{ }^{\circ} \mathrm{C} ; t_{\text {ion }}=0.82 \\
\text { Unplasticized SPE: } \\
\sigma=1.02 \times 10^{-5} \mathrm{~S} \mathrm{~cm}^{-1} ; T_{g}=68^{\circ} \mathrm{C}\end{array}$ & [111] \\
\hline PVDF-HFP-LiClO ${ }_{4}-\mathrm{SN}$ & Solution casting & $\sim 1.62 \times 10^{-3}\left(20^{\circ} \mathrm{C}\right)$ & $\begin{array}{c}E_{A}=0.40 \mathrm{eV} \\
\text { Unplasticized SPE: } \\
\sigma=\sim 6.38 \times 10^{-9} \mathrm{~S} \mathrm{~cm}^{-1}\left(20^{\circ} \mathrm{C}\right) \\
E_{A}=0.69 \mathrm{eV}\end{array}$ & [105] \\
\hline PVDF-HFP-LiBETI-SN & Solution casting & $\sim 2.58 \times 10^{-3}\left(20^{\circ} \mathrm{C}\right)$ & $\begin{array}{c}\mathrm{LiCoO}_{2} / \mathrm{SPE} / \mathrm{Li}_{4} \mathrm{Ti}_{5} \mathrm{O}_{12} \text { cell }(\mathrm{C} / 10, \\
\left.25^{\circ} \mathrm{C}\right): \\
\text { Initial discharge capacity } \\
116 \mathrm{mAh} \mathrm{g} \mathrm{g}^{-1}, 78 \% \text { capacity } \\
\text { retention after } 120 \text { th cycle }\end{array}$ & [105] \\
\hline PVDF-PEO-LiClO ${ }_{4}-\mathrm{SN}$ & $\begin{array}{l}\text { Solution infiltration } \\
\text { in PVDF film + } \\
\text { drying }\end{array}$ & $2.80 \times 10^{-5}\left(25^{\circ} \mathrm{C}\right)$ & $\begin{array}{c}T_{g}=-75.6{ }^{\circ} \mathrm{C} ; t_{L i+}=0.37\left(25^{\circ} \mathrm{C}\right) \\
\mathrm{LiFePO}_{4} / \mathrm{SPE} / \mathrm{Li}: \\
\mathrm{OCV}=3.1 \mathrm{~V} \text {, discharge capacity } \\
109 \mathrm{mAh} \mathrm{g}{ }^{-1} \text { (100th cycle), } 90 \% \\
\text { capacity retention }\end{array}$ & [112] \\
\hline $\begin{array}{c}\mathrm{PEO}-\mathrm{LiCF}_{3} \mathrm{SO}_{3}-\mathrm{TiO}_{2-} \\
\mathrm{EC} \\
{[\mathrm{EO}] /[\mathrm{Li}]=9: 1}\end{array}$ & Solution casting & $1.60 \times 10^{-4}\left(30^{\circ} \mathrm{C}\right)$ & $\begin{array}{c}E_{A}=0.60 \mathrm{eV} ; T_{g}=-50{ }^{\circ} \mathrm{C} ; \\
T_{m}=50^{\circ} \mathrm{C}\end{array}$ & [43] \\
\hline PEO-KI-PEG & Solution casting & $5.27 \times 10^{-5}\left(25^{\circ} \mathrm{C}\right)$ & $\begin{array}{c}\text { Unblended PEO-KI SPE: } \\
\sigma=1.96 \times 10^{-5} \mathrm{~S} \mathrm{~cm}^{-1}\left(25^{\circ} \mathrm{C}\right) \\
\text { Low } \mathrm{M}_{\mathrm{W}} \text { of PEG }(\sim 4000) \text { might be } \\
\text { trapped or crosslink in PEO-KI } \\
\text { network }\end{array}$ & [113] \\
\hline PEO-LiTFSI-S 2 TFSI & $\begin{array}{l}\text { Mixing, } \\
\text { vacuum-sealed in } \\
\text { pouch and hot press }\end{array}$ & $\begin{array}{l}0.96 \times 10^{-3}\left(22^{\circ} \mathrm{C}\right) \\
4.00 \times 10^{-3}\left(60^{\circ} \mathrm{C}\right)\end{array}$ & $\begin{array}{c}t_{\mathrm{Li+}}=0.31\left(60^{\circ} \mathrm{C}\right) \\
\mathrm{LiFePO}_{4} / \mathrm{SPE} / \mathrm{Li}: \\
\text { Discharge capacity }\left(1 \mathrm{C}, 60^{\circ} \mathrm{C}\right)= \\
160.1 \mathrm{mAh} \mathrm{g}^{-1}(500 \text { th cycle }), 89.9 \% \\
\text { capacity retention }\end{array}$ & [114] \\
\hline $\begin{array}{c}\text { PEO-LiFSI-N }{ }_{1222} \text { FSI } \\
{[\mathrm{EO}] /[\mathrm{Li}]=20: 1}\end{array}$ & Solution casting & $\begin{array}{l}1.78 \times 10^{-5}\left(25^{\circ} \mathrm{C}\right) \\
2.14 \times 10^{-4}\left(50^{\circ} \mathrm{C}\right)\end{array}$ & $\begin{array}{c}T_{g}=-58.1^{\circ} \mathrm{C} ; \% \chi_{C}=24.7 \% \\
\text { High thermal stability with } \\
\text { decomposition temperature above } \\
220^{\circ} \mathrm{C} \\
\mathrm{LiFePO}_{4} / \mathrm{SPE} / \mathrm{Li}: \\
\text { Discharge capacity }\left(0.2 \mathrm{C}, 50^{\circ} \mathrm{C}\right)= \\
151.5 \mathrm{mAh} \mathrm{g}^{-1}(120 \text { th cycle }), 95.4 \% \\
\text { capacity retention } \\
\text { Unplasticized SPE: } \\
\sigma=7.24 \times 10^{-7} \mathrm{~S} \mathrm{~cm}^{-1}\left(25^{\circ} \mathrm{C}\right) \\
T_{g}=-44.8^{\circ} \mathrm{C} ; \% \mathrm{XC}=33.6 \%\end{array}$ & [115] \\
\hline $\begin{array}{c}\text { PEO:MC } \\
(60: 40)-\mathrm{NH}_{4} \mathrm{I}-\mathrm{PEG} \\
\left(\mathrm{M}_{\mathrm{W}} \mathrm{PEG} 8000\right)\end{array}$ & Solution casting & $3.37 \times 10^{-3}\left(30^{\circ} \mathrm{C}\right)$ & $\begin{array}{c}E_{A}=0.0322 \mathrm{eV} \\
\text { Unplasticized SPE: } \\
\sigma=7.62 \times 10^{-5} \mathrm{~S} \mathrm{~cm}^{-1}\left(30^{\circ} \mathrm{C}\right) \\
E_{A}=0.0465 \mathrm{eV}\end{array}$ & {$[116,117]$} \\
\hline
\end{tabular}


Table 6. Cont.

\begin{tabular}{|c|c|c|c|c|}
\hline Electrolyte System & $\begin{array}{l}\text { Preparation } \\
\text { Method }\end{array}$ & $\begin{array}{l}\text { Conductivity, } \sigma \\
\left(\mathrm{S} \mathrm{cm}^{-1}\right)\end{array}$ & Important Findings & Reference \\
\hline $\begin{array}{l}\mathrm{PMMA}^{\mathrm{M}} \mathrm{LiClO}_{4}-\mathrm{PC} \\
{[\mathrm{MMA}] /[\mathrm{Li}]=4: 1}\end{array}$ & Solution casting & $3.52 \times 10^{-5}\left(30^{\circ} \mathrm{C}\right)$ & $\begin{array}{c}\qquad E_{A}=0.11 \mathrm{eV} \\
\text { Conduction and relaxation via } \\
\text { hopping mechanism }\end{array}$ & [118] \\
\hline $\begin{array}{l}\text { PVA- } \mathrm{LiClO}_{4} \text {-DMP } \\
(30: 10: 60)\end{array}$ & Solution casting & $0.15 \times 10^{-3}\left(29^{\circ} \mathrm{C}\right)$ & $\begin{array}{l}\text { Conductivity-temperature relation } \\
\text { obeys Vogel-Tamman-Fulcher } \\
\text { (VTF) rule }\end{array}$ & [119] \\
\hline $\begin{array}{c}\text { PVA- } \mathrm{LiCF}_{3} \mathrm{SO}_{3}-\mathrm{DMP} \\
(30: 10: 60)\end{array}$ & Solution casting & $\sim 6.35 \times 10^{-5}\left(29^{\circ} \mathrm{C}\right)$ & $\begin{array}{l}\text { Conductivity-temperature relation } \\
\text { obeys Vogel-Tamman-Fulcher } \\
\text { (VTF) rule }\end{array}$ & [119] \\
\hline $\begin{array}{l}\text { PVA-LiBF } 4 \text {-DMP } \\
(30: 10: 60)\end{array}$ & Solution casting & $\sim 1.66 \times 10^{-5}\left(29^{\circ} \mathrm{C}\right)$ & $\begin{array}{l}\text { Conductivity-temperature relation } \\
\text { obeys Vogel-Tamman-Fulcher } \\
\text { (VTF) rule }\end{array}$ & [119] \\
\hline $\begin{array}{c}\text { PEO-LiCF } \mathrm{SO}_{3}-15 \text { wt.\% } \\
\text { PEG }\left(\mathrm{M}_{\mathrm{w}} \text { PEG 6000) }\right.\end{array}$ & $\begin{array}{l}\text { Ball-milling and hot } \\
\text { press }\end{array}$ & $1.71 \times 10^{-5}$ & $T_{g}=-55.8{ }^{\circ} \mathrm{C} ; \% \chi_{C}=31.6 \%$ & {$[38]$} \\
\hline $\begin{array}{c}\text { PEO-LiCF } \mathrm{SO}_{3}-20 \text { wt. } \% \\
\text { DOP }\end{array}$ & $\begin{array}{l}\text { Ball-milling and hot } \\
\text { press }\end{array}$ & $7.60 \times 10^{-4}$ & $T_{g}=-63.9{ }^{\circ} \mathrm{C} ; \% \chi_{C}=23.1 \%$ & {$[38]$} \\
\hline $\begin{array}{c}\text { PEO-LiCF } \mathrm{SO}_{3}-20 \text { wt.\% } \\
\text { EC }\end{array}$ & Solution casting & $8.12 \times 10^{-5}\left(25^{\circ} \mathrm{C}\right)$ & $\begin{array}{c}\mathrm{T}_{g}=-70.5^{\circ} \mathrm{C} ; \% \chi_{C}=31.3 \% \\
\text { Without plasticizer: } \\
\sigma=2.89 \times 10^{-5} \mathrm{~S} \mathrm{~cm}^{-1}\left(25^{\circ} \mathrm{C}\right) \\
T_{g}=-69.0^{\circ} \mathrm{C} ; \% \chi_{C}=31.7 \%\end{array}$ & [120] \\
\hline $\begin{array}{c}\text { Corn } \\
\text { starch-LiPF }{ }_{6}-\text { BmImTf }^{-}\end{array}$ & Solution casting & $6.00 \times 10^{-4}\left(80^{\circ} \mathrm{C}\right)$ & $\begin{array}{c}E_{A}=0.01 \mathrm{eV} ; T_{\mathrm{g}}=-29^{\circ} \mathrm{C} \\
\text { Without plasticizer: } \\
\sigma=\sim 10^{-6} \mathrm{~S} \mathrm{~cm}^{-1}\left(80^{\circ} \mathrm{C}\right) \\
E_{\mathrm{A}}=0.13 \mathrm{eV} ; T_{g}=-19^{\circ} \mathrm{C}\end{array}$ & [121] \\
\hline CMC-LiBF 4 -glycerol & Solution casting & $3.70 \times 10^{-3}\left(25^{\circ} \mathrm{C}\right)$ & $\begin{array}{c}T_{g}=54^{\circ} \mathrm{C} \\
T_{g} \text { of } \mathrm{CMC} \text { film }=87^{\circ} \mathrm{C} \\
\text { Without glycerol: } \\
\sigma=8.20 \times 10^{-6} \mathrm{~S} \mathrm{~cm}^{-1}\left(25^{\circ} \mathrm{C}\right)\end{array}$ & [122] \\
\hline $\begin{array}{c}\mathrm{PVA}_{-} \mathrm{CH}_{3} \mathrm{COONH}_{4}^{-} \\
\text {BmImI }\end{array}$ & Solution casting & $9.63 \times 10^{-5}\left(25^{\circ} \mathrm{C}\right)$ & $\begin{array}{c}E_{A}=6.68 \mathrm{meV} ; \% \chi_{C}=2 \% \\
D^{+}=9.80 \times 10^{-12} \mathrm{~cm}^{2} \mathrm{~s}^{-1} \\
\text { EDLC at scan rate } 10 \mathrm{mV} \mathrm{s}^{-1} \\
\text { 200th cycle: } \\
\text { Specific capacitance }=44.46 \mathrm{~F} \mathrm{~g}^{-1} \\
\text { Power density }=47.66 \mathrm{~kW} \mathrm{~kg}-1 \\
\text { Without BmImI: } \\
\sigma=1.94 \times 10^{-5} \mathrm{~S} \mathrm{~cm}^{-1}\left(25^{\circ} \mathrm{C}\right)\end{array}$ & [123] \\
\hline Chitosan- $\mathrm{NH}_{4} \mathrm{I}-\mathrm{BmImI}$ & Solution casting & $3.43 \times 10^{-5}\left(27^{\circ} \mathrm{C}\right)$ & $\begin{array}{c}E_{A}=0.25 \mathrm{eV} \\
\mathrm{N} 3 / \mathrm{TiO}_{2} / \mathrm{SPE} / \mathrm{Pt} \mathrm{DSSC}(\text { light } \\
\left.\text { intensity of } 100 \mathrm{~mW} \mathrm{~cm}^{-2}\right): \\
\mathrm{OCV}=0.58 \mathrm{~V} ; J_{s c}=3.10 \mathrm{~mA} \mathrm{~cm}^{-2} ; \\
F F=0.41 ; \eta=0.74 \% \\
\text { Without } \mathrm{BmImI} \\
\sigma=3.73 \times 10^{-7} \mathrm{~S} \mathrm{~cm}^{-1}\left(27^{\circ} \mathrm{C}\right)\end{array}$ & [124] \\
\hline $\begin{array}{c}\text { PEO-LiTFSI-30 wt. } \% \\
\text { TCNE } \\
{[\mathrm{EO}] /[\mathrm{Li}]=12: 1}\end{array}$ & Solution casting & $1.11 \times 10^{-4}\left(25^{\circ} \mathrm{C}\right)$ & $\begin{array}{c}T_{g}=-46.21^{\circ} \mathrm{C} \\
\text { Without } \mathrm{TCNE}: \\
\sigma=1.21 \times 10^{-5} \mathrm{~S} \mathrm{~cm}^{-1}\left(25^{\circ} \mathrm{C}\right) \\
T_{g}=-43.03^{\circ} \mathrm{C}\end{array}$ & [125] \\
\hline
\end{tabular}


Table 6. Cont.

\begin{tabular}{|c|c|c|c|c|}
\hline Electrolyte System & $\begin{array}{l}\text { Preparation } \\
\text { Method }\end{array}$ & $\begin{array}{l}\text { Conductivity, } \sigma \\
\left(\mathrm{S} \mathrm{cm}^{-1}\right)\end{array}$ & Important Findings & Reference \\
\hline $\begin{array}{l}\text { Chitosan-NaI-I }{ }_{2-}^{-} \\
\text {EMImSCN }\end{array}$ & Solution casting & $2.60 \times 10^{-4}(\mathrm{RT})$ & $\begin{array}{c}\mathrm{N} 719 / \mathrm{TiO}_{2} / \mathrm{SPE} / \mathrm{Pt} \mathrm{DSSC} \text { (light } \\
\left.\text { intensity of } 100 \mathrm{~mW} \mathrm{~cm}^{-2}\right): \\
\mathrm{OCV}=0.53 \mathrm{~V} ; J_{S C}=2.62 \mathrm{~mA} \mathrm{~cm} \mathrm{~cm}^{-2} \\
F F=0.52 ; \eta=0.73 \% \\
\text { Without EMImSCN: } \\
\sigma=1.21 \times 10^{-5} \mathrm{~S} \mathrm{~cm}^{-1}\left(25^{\circ} \mathrm{C}\right) \\
\mathrm{OCV}=0.35 \mathrm{~V} ; J_{S C}=1.05 \mathrm{~mA} \mathrm{~cm}{ }^{-2} ; \\
F F=0.34 ; \eta=0.13 \%\end{array}$ & [126] \\
\hline $\begin{array}{c}\text { PVDF-KI-I } I_{2}-30 \text { wt. } \% \\
\text { MCP }\end{array}$ & Solution casting & $4.58 \times 10^{-5}\left(30^{\circ} \mathrm{C}\right)$ & 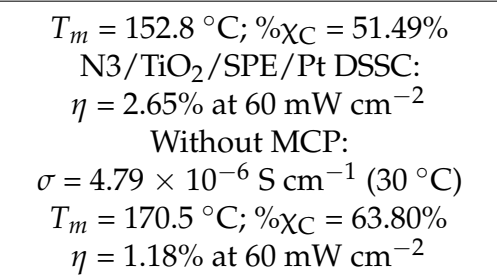 & [127] \\
\hline $\begin{array}{l}\text { PVDF-HFP-KI-TBAI-I }{ }_{2}^{-} \\
4 \text { wt. } \% \text { ATDT }\end{array}$ & Solution casting & $2.82 \times 10^{-4}\left(30^{\circ} \mathrm{C}\right)$ & $\begin{array}{c}\text { Porous surface morphology } \\
\mathrm{N} / \mathrm{TiO}_{2} / \mathrm{SPE} / \mathrm{Pt} \mathrm{DSSC}: \\
\eta=4.64 \% \text { at } 60 \mathrm{~mW} \mathrm{~cm} \mathrm{~m}^{-2} \\
\text { Without } \mathrm{ATDT}: \\
\sigma=9.99 \times 10^{-6} \mathrm{~S} \mathrm{~cm}^{-1}\left(30^{\circ} \mathrm{C}\right) \\
\eta=1.88 \% \text { at } 60 \mathrm{~mW} \mathrm{~cm}^{-2}\end{array}$ & [128] \\
\hline $\begin{array}{l}\text { PVDF-HFP-NaI- } \\
\text { EMImSCN }\end{array}$ & Solution casting & $2.65 \times 10^{-3}\left(30^{\circ} \mathrm{C}\right)$ & $\begin{array}{c}\text { Electrochemical stability } \\
\text { window } 3.6 \mathrm{~V} \\
\text { EDLC at scan rate } 0.05 \mathrm{mV} \mathrm{s}^{-1} \text { : } \\
\text { Specific capacitance }=2.36 \mathrm{~F} \mathrm{~g}^{-1}\end{array}$ & [129] \\
\hline $\begin{array}{l}\text { P(GMA-co-MMA)- } \\
\text { LiClO }_{4}-\mathrm{EC}\end{array}$ & Solution casting & $3.00 \times 10^{-4}(\mathrm{RT})$ & $\begin{array}{c}\text { Electrochemical stability } \\
\text { window } 3.8 \mathrm{~V} \\
\text { Without EC: } \\
\sigma=8.70 \times 10^{-6} \mathrm{~S} \mathrm{~cm}^{-1}(\mathrm{RT})\end{array}$ & [65] \\
\hline $\begin{array}{l}\text { PVAc:PMMA } \\
\text { (70:30)-LiCl-EC }\end{array}$ & Solution casting & $1.03 \times 10^{-4}\left(30^{\circ} \mathrm{C}\right)$ & $\begin{array}{c}T_{g}=26.6^{\circ} \mathrm{C} ; \mathrm{t}_{+}=0.98 \\
D_{+}=7.00 \times 10^{-11} \mathrm{~cm}^{2} \mathrm{~s}^{-1} \\
\mu=2.68 \times 10^{-9} \mathrm{~cm}^{2} \mathrm{~V}^{-1} \mathrm{~s}^{-1} \\
n=2.35 \times 10^{22} \mathrm{~cm}^{-3} \\
\text { Without plasticizer: } \\
\sigma=1.03 \times 10^{-5} \mathrm{~S} \mathrm{~cm}^{-1}\left(30^{\circ} \mathrm{C}\right) \\
T_{g}=42.6^{\circ} \mathrm{C} ; \mathrm{t}_{+}=0.97 \\
D_{+}=6.93 \times 10^{-11} \mathrm{~cm}^{2} \mathrm{~s}^{-1} \\
\mu=2.65 \times 10^{-9} \mathrm{~cm}^{2} \mathrm{~V}^{-1} \mathrm{~s}^{-1} \\
n=2.35 \times 10^{22} \mathrm{~cm}^{-3}\end{array}$ & [99] \\
\hline
\end{tabular}

PGMA - poly glycidyl methacrylate; $\mathrm{SN}$ - succinonitrile; $\mathrm{HEC}$-hydroxyethylcellulose; $\mathrm{PVB}_{-}$- polyvinyl butyral; $\mathrm{NH}_{4} \mathrm{CF}_{3} \mathrm{SO}_{3}-\mathrm{ammonium}_{2}$ trifluoromethane sulfonate; BMATFSI-butyl trimethylammonium bis(trifluoromethanesulfonyl)imide; LiBETI-lithium bisperfluoroethylsulfonylimide $\left(\mathrm{Li}\left(\mathrm{C}_{2} \mathrm{~F}_{5} \mathrm{SO}_{2}\right)_{2} \mathrm{~N}\right) ; \mathrm{LiCoO}_{2}$-lithium cobalt oxide; $\mathrm{S}_{2} \mathrm{TFSI}$-triethylsulfonium bis(trifluoromethylsulfonyl)imide; LiFSIlithium bis(fluorosulfonyl)imide; $\mathrm{N}_{1222} \mathrm{FSI}$ - triethylmethylammonium bis(fluorosulfonyl)imide; DMP—dimethyl phthalate; DOP_dioxy phthalate; BmImTf-1-butyl-3-methylimidazolium trifluoromethanesulfonate; $\mathrm{CH}_{3} \mathrm{COONH}_{4}$-ammonium acetate; BmImI-1-butyl-3methylimidazolium iodide; TCNE_tetracyanoethylene; EMImSCN-1-ethyl 3-methylimidazolium thiocyanate; MCP-2-mercatopyridine; ATDT-5-amino-1,3,4-thiadiazole-2-thiol.

It is interesting to highlight that ionic liquids can play three roles, viz as plasticizer (to enhance the flexibility of polymer backbone), conducting salt (provides cation and anion) and solvent. They are non-volatile, safe (due to non-flammability), chemically and thermally stable, and are not prone to evaporation and crystallization [130]. In addition, they exhibit low melting temperature and outstanding ionic conductivity at room temperature condition, and they also have superior solvating ability. In the work of Widstrom et al. [114], increment in conductivity has been observed after incorporating ionic liquid, $\mathrm{S}_{2}$ TFSI into 
PEO-LiTFSI SPE without affecting $\mathrm{Li}^{+}$transference number. From Table 6, it is to be noted that $\mathrm{N}_{1222} \mathrm{FSI}$ is not an ionic liquid but an ionic plastic crystal that shows similar features to that of ionic liquids [115]. In contrast to conventional plasticizers, the mechanical integrity can still be retained upon addition of $\mathrm{N}_{1222} \mathrm{FSI}$ into the electrolyte besides reducing the polymer crystallinity and dissociating the salt. Moreover, the interfacial contact between electrolyte and electrode can be improved [115].

Another organic plastic crystal, i.e., succinonitrile (SN) is favored for its outstanding solvating capability in dissociating many salts including Li-based salts in battery application. As a result, conductivity is enhanced as can be observed in refs [105,112] from Table 6. Unfortunately, the plastic nature of SN deteriorates the mechanical strength of the electrolyte. Nonetheless, this can be easily avoided by preparing the electrolyte membrane in a different way. He et al. [131] prepared free-standing film containing PEGDA $\left(\mathrm{M}_{\mathrm{W}} 6000 \mathrm{~g} \mathrm{~mol}^{-1}\right)$, LiTFSI and SN via photopolymerization procedure using bis $(2,4,6-$ trimethylbenzoyl)-phenylphosphine oxide (also known as Irgacure 819) as photo-initiator but without solvent. Such electrolyte which was highly amorphous with crosslinking network exhibited good ambient conductivity of $1.10 \times 10^{-3} \mathrm{~S} \mathrm{~cm}^{-1}$, electrochemical stability window of $4.80 \mathrm{~V}$ with improved mechanical strength (0.24 MPa tensile strength, $84 \%$ elongation at break). $\mathrm{Li}_{4} \mathrm{Ti}_{5} \mathrm{O}_{12} / \mathrm{Li}$ cell employing this electrolyte gave promising performance (The first discharge capacity of $140 \mathrm{mAh} \mathrm{g}^{-1}$ at $0.2 \mathrm{C}$ ) with $93 \%$ capacity retention for $25 \mathrm{cy}-$ cles [131]. On the other hand, it is evident from Table 6 that PEG of low molecular weight acted as plasticizer rather than secondary polymer in PEO-KI electrolyte which showed better conductivity [113] than PEG-free SPE even though PEG might have crosslinked with PEO. Instead, conductivity improvement is attributed to extra passageways for ion migration through PEG segmental movement.

\subsubsection{Composite Solid Polymer Electrolytes}

Although addition of plasticizers in SPEs can easily improve the ionic conductivity, the mechanical strength of the SPEs is compromised. On the contrary, incorporating fillers in SPEs is known to improve the performance of SPEs not merely the ionic conductivity but also its mechanical strength since fillers can reduce the crystallinity of SPE films. SPE incorporated with an inorganic filler are termed as composite solid polymer electrolytes (CSPEs). In most CSPEs systems, the polymer is usually regarded as Lewis base if it donates its lone pair of electrons, while the filler is a Lewis acid in accepting the electrons. Fillers can be categorized into two types, i.e., active and inactive. Some examples of inactive fillers are titanium dioxide $\left(\mathrm{TiO}_{2}\right)$, silicon dioxide $\left(\mathrm{SiO}_{2}\right)$, alumina $\left(\mathrm{Al}_{2} \mathrm{O}_{3}\right)$ and zirconia $\left(\mathrm{ZrO}_{2}\right)$. The effects of fillers are varied depending on their particles size, surface nature and amount or concentration in the CSPEs.

Tan et al. [132] investigated the effect of $\mathrm{SiO}_{2}$ and $\mathrm{Al}_{2} \mathrm{O}_{3}$ on the PMMA-based SPEs containing $\mathrm{LiCF}_{3} \mathrm{SO}_{3}$ salt. Addition of $\mathrm{Al}_{2} \mathrm{O}_{3}$ has improved the ionic conductivity by one order of magnitude from $1.36 \times 10^{-5} \mathrm{~S} \mathrm{~cm}^{-1}$ to $2.05 \times 10^{-4} \mathrm{~S} \mathrm{~cm}^{-1}$. However, this effect cannot be seen for $\mathrm{CSPE}$ containing $\mathrm{SiO}_{2}$ [132]. The reason behind $\mathrm{Al}_{2} \mathrm{O}_{3}$ showed significant improvement in conductivity may be because of the $\mathrm{OH}$ surface nature in alumina that provided additional coordination sites to oxygen atom in PMMA for ionic conduction. Moreover, the presence of $\mathrm{H}^{+}$on the alumina surface also help in salt dissociation thus increasing the number density of ions leading to ionic conductivity improvement of the CSPE [132]. In the same work, they also reported that the amount of $\mathrm{Al}_{2} \mathrm{O}_{3}$ influenced the conductivity of CSPE [132]. The presence of high amount of alumina grains in CSPE may cause the polymer chain to be less mobile thus affecting the transport of ions that resulted in conductivity decrement. Nonetheless, it has been reported that the mechanical strength of CSPE was enhanced at high concentrations of filler [133]. Too much or too low content of fillers would not bring positive effect on the ionic conductivity [134]. Only at optimized concentration can lead to its improvement in the CSPE [134]. The findings on acidic surface nature of alumina that enhanced the conductivity of SPE [132] are also supported by Croce et al. [135]. Following Reference [135], it can be understood that extra pathway for ion 
transport was formed via hydrogen bonding when the surface of $\mathrm{Al}_{2} \mathrm{O}_{3}$ nanofiller (particle size $5.8 \mathrm{~nm}$ ) was acidic. The SPE system that comprised $\mathrm{PEO}, \mathrm{LiCF}_{3} \mathrm{SO}_{3}$ and acidic $\mathrm{Al}_{2} \mathrm{O}_{3}$ exhibited ionic conductivity of $2.10 \times 10^{-5} \mathrm{~S} \mathrm{~cm}^{-1}$ at $30^{\circ} \mathrm{C}$. Slight reduction in conductivity $\left(1.20 \times 10^{-5} \mathrm{~S} \mathrm{~cm}^{-1}\right.$ at $\left.30^{\circ} \mathrm{C}\right)$ was observed for $\mathrm{Al}_{2} \mathrm{O}_{3}$ neutral surface which may be due to weaker interactions as compared to that in acidic form [135]. On the contrary, there was no interaction between filler, anion of salt and polymer in the case of basic $\mathrm{Al}_{2} \mathrm{O}_{3}$ surface thus subsequently causing detrimental outcome to conductivity $\left(7.30 \times 10^{-6} \mathrm{~S} \mathrm{~cm}^{-1}\right.$ at $\left.30{ }^{\circ} \mathrm{C}\right)[135]$.

In another work, it was also observed that the addition of $\mathrm{SiO}_{2}$ successfully boosted the ionic conductivity for PVA-PVP-PEG-NaI electrolyte [136]. An improvement in amorphous region of the electrolyte film via the interaction of functional groups of the polymer with the Si-O-Si of the filler may be the reason for the conductivity increase. $\mathrm{Li}$ and Lian [137] studied the effect of $\mathrm{SiO}_{2}$ particle sizes $(4 \mu \mathrm{m}$ and $7 \mathrm{~nm})$ in hydroxide conducting poly(acrylamide) (PAM) based SPE for alkaline batteries. The hydroxide conductivity of the SPE was amplified with the incorporation of $7 \mathrm{~nm} \mathrm{SiO} 2$ but not for SPE containing $4 \mu \mathrm{m} \mathrm{SiO}{ }_{2}$. Based on the micrographs and Raman studies, smaller size of $\mathrm{SiO}_{2}$ significantly helped to delay polymer crystallization [137]. Similar observation has been reported for $\mathrm{Al}_{2} \mathrm{O}_{3}$ where the smaller particle size prevented the formation of dendrites [138]. Other than size, the morphology of filler will also give different outcome to the CSPE. Lithium dendrites formation was minimized in the case of electrolyte containing PEO, lithium (bis trifluoromethyl)sulfate, $\mathrm{SCN}$ and $\mathrm{SiO}_{2}$ nanofibers as compared to similar electrolyte but with $\mathrm{SiO}_{2}$ nanoparticles [139]. It was observed that $\mathrm{SiO}_{2}$ aggregates was found in the latter, while the $\mathrm{SiO}_{2}$ nanofibers were homogeneously distributed in the electrospun CSPE as evidenced from SEM images. The CSPE of $\mathrm{SiO}_{2}$ nanofibers that had a 3D structure demonstrated better mechanical strength and flexibility with improved performance in lithium battery [139]. Incorporation of filler in electrolyte also yielded better interfacial contact with lithium metal electrode [140]. At $30^{\circ} \mathrm{C}, \mathrm{SiO}_{2}$ nanofibers CSPE exhibited the conductivity of $9.32 \times 10^{-5} \mathrm{~S} \mathrm{~cm}^{-1}$ which was highest when comparing to CSPE with $\mathrm{SiO}_{2}$ nanoparticles $\left(5.28 \times 10^{-5} \mathrm{~S} \mathrm{~cm}^{-1}\right)$ and SPE without $\mathrm{SiO}_{2}\left(4.72 \times 10^{-5} \mathrm{~S} \mathrm{~cm}^{-1}\right)$ [139]. Occasionally, an increment in cationic transference number was observed upon the addition of fillers in SPEs [3].

As discussed earlier, the contribution of inactive or passive fillers in ionic conductivity of SPEs is clear, i.e., improving the mobility of charge carriers either through the mobility of polymer chain (amorphousness) or by providing the additional transportation sites. Active fillers, such as $\mathrm{Li}_{1+x} \mathrm{Al}_{x} \mathrm{Ge}_{2-x}\left(\mathrm{PO}_{4}\right)_{3}$ [141], $\mathrm{Li}_{1+x} \mathrm{Al}_{x} \mathrm{Ti}_{2-x}\left(\mathrm{PO}_{4}\right)_{3}$ [142], $\mathrm{Li}_{7} \mathrm{La}_{3} \mathrm{Zr}_{2} \mathrm{O}_{12}$ [143], $\mathrm{Li}_{0.33} \mathrm{La}_{0.557} \mathrm{TiO}_{3}$ [144] and $\mathrm{Li}_{6.4} \mathrm{La}_{3} \mathrm{Zr}_{1.4} \mathrm{Ta}_{0.6} \mathrm{O}_{12}$ [145] on the other hand, contribute directly to the lithium-ion conductivity apart from impeding crystallization and improving the mechanical integrity of the SPEs. These materials by their own serve as solid electrolytes [146-150]. Nonetheless, the fabrication processes of these ceramics are usually complicated and costly [139]. In addition, the thickness of these solid electrolytes have to be large (around $100 \mu \mathrm{m}$ in pellet form), since they are fragile and brittle [139] thus resulting in high interfacial resistance. These drawbacks lead to introducing them in SPEs as fillers instead. Filler-added SPEs are flexible, more stable and have better interfacial compatibility with Li metal electrodes [141,151]. Furthermore, the SPEs possess better processability and higher ionic conductivity than the solid electrolytes [151,152]. Similar to inactive fillers, the size, concentration and morphology of active fillers impose different impact on the CSPEs.

Among the inorganic active fillers, $\mathrm{Li}_{7} \mathrm{La}_{3} \mathrm{Zr}_{2} \mathrm{O}_{12}$ (LLZO) having garnet structure is favored due to its chemical stability against lithium metal and large electrochemical window ( $>5 \mathrm{~V})$ [143]. LLZO nanofibers prepared via the electrospinning method have been introduced to an electrolyte comprising PVDF-HFP as a polymer host, LiTFSI salt and ionic liquid plasticizer [153]. The CSPE delivered high ambient conductivity $\left(6.50 \times 10^{-3} \mathrm{~S} \mathrm{~cm}^{-1}\right)$, reduced crystallinity and wide electrochemical window $(5.3 \mathrm{~V})$ than plasticized SPE without LLZO as filler [153]. Comparison was made with basic SPE configuration of PVDF-HFPLiTFSI in electrochemical performance of Li-ion battery. The LLZO CSPE cell displayed 
good cyclability over 1000 cycles with specific capacity of $149 \mathrm{mAh} \mathrm{g}^{-1}$, whereas the capacity decreased sharply after 50th cycle for the Li-ion cell with basic SPE [153]. Synergistic effect of LLZO filler and poly(ethylene glycol) dimethyl ether (PEGDME) plasticizer was also studied in PEO-LiTFSI SPEs system [154]. Again, improvements in conductivity, Liion transference number and electrochemical performance were reported [154]. In the work of Keller et al. [155], LLZO-added CSPE containing PEO and LiTFSI did not contribute to ionic conductivity but exhibited improved electrolyte-electrode interfacial contact and higher electrochemical performance in lithium battery. It was found that the addition of LLZO in SPEs suppressed lithium dendrites growth [152-156]. The lithium and zirconium sites of LLZO can be doped with other elements to boost its properties. Zhang and coauthors [157] employed tantalum (Ta) as dopant in LLZO to form $\mathrm{Li}_{6.75} \mathrm{La}_{3} \mathrm{Zr}_{1.75} \mathrm{Ta}_{0.25} \mathrm{O}_{12}$ (LLZTO). The PAN-LiClO 4 -LLZTO CSPE showed conductivity increment by 12 times $\left(2.20 \times 10^{-4} \mathrm{~S} \mathrm{~cm}^{-1}\right.$ at $\left.40^{\circ} \mathrm{C}\right)$ and higher $\mathrm{Li}^{+}$transference number of 0.30 than filler-free SPE [157]. In addition, the CSPE was thermally and electrochemically stable with enhanced mechanical strength [157]. It is worthy to mention that $\mathrm{Li}^{+}$transference number as high as 0.75 was obtained in CSPE containing LLZTO, poly(propylene carbonate) and LiTFSI with conductivity of $5.20 \times 10^{-4} \mathrm{~S} \mathrm{~cm}^{-1}$ at $20^{\circ} \mathrm{C}$ [158]. It is understood that the addition of nano-sized LLZTO promoted salt dissociation due to the interactions between polymer, cation and filler and subsequently impeded the diffusion of anions [158].

LLZO is preferred over NASICON-type $\mathrm{Li}_{1.5} \mathrm{Al}_{0.5} \mathrm{Ge}_{1.5}\left(\mathrm{PO}_{4}\right)_{3}$ (LAGP) due to their inexpensive elements [155]. In contrast, germanium in the latter is costly [155]. Nevertheless, LLZO has shortcomings; for example, it has an unstable at room-temperature condition, and thus, it is reactive towards moisture and humidity [155]. Similar to LLZO, LAGP is also unreactive towards lithium metal electrodes and has been used as a filler in polymer electrolytes. PEO, LiTFSI and LAGP were mixed and ground without solvent before heating and hot-pressing to form CSPE as reported by Piana et al. [159]. The CSPE showed improvements in term of conductivity, mechanical integrity and specific capacity as compared to electrolyte without filler [159]. On the other hand, the prepared CSPE in Reference [159] showed superior interfacial contact than pelletized LAGP solid electrolyte in lithium-ion cells. However, no significant change in lithium-ion transference number was observed with the introduction of LAGP in PEO-based electrolyte. On the contrary, LAGP added in poly(propylene carbonate)-based electrolyte increased lithium-ion transference number to 0.77 with conductivity of $0.56 \times 10^{-3} \mathrm{~S} \mathrm{~cm}^{-1}$ and improved cyclability and stability in Li-ion battery [160].

Li et al. [13] employed electrospinning technique to synthesize $\mathrm{Li}_{0.33} \mathrm{La}_{0.557} \mathrm{TiO}_{3}$ nanorodsbefore adding in PVDF-HFP electrolyte containing LiTFSI salt. The CSPE was more thermally stable and showed decreased crystallinity with higher ambient ionic conductivity $\left(1.21 \times 10^{-4} \mathrm{~S} \mathrm{~cm}^{-1}\right)$ and tensile strength $(39.77 \mathrm{MPa})$ than filler-free electrolyte $\left(\sigma=4.72 \times 10^{-5} \mathrm{~S} \mathrm{~cm}^{-1}\right.$; tensile strength $\left.=38.41 \mathrm{MPa}\right)$ [13]. Ionic conductivity of PANbased SPE has been shown to increase with the help of an active filler namely lithium titanate nanotubes (LiTNT) [161]. From the vibrational studies, Pignanelli and co-workers observed that the presence of LiTNT in SPE helped in the increment of lithium perchlorate dissociation, whereas the impedance spectroscopy showed two semicircles that are related to lithium-ion conductivity [161]. The semicircle in the higher frequency region is accredited to the bulk resistance of lithium transport across the polymer matrix, whereas the second is ascribed to lithium transport through the interaction with the LiTNT [161]. Some authors have proposed that lithium transport can take place via three possible routes, i.e., polymer-salt matrix, polymer-filler interface and inside filler grain [162,163]. Zheng et al. [163] showed that Li-ion movement took place mainly via ceramic filler LLZO grain for $\mathrm{PEO}-\mathrm{LiClO}_{4}$-LLZO system, using NMR results. On the other hand, for $\mathrm{PEO}-\mathrm{LiClO}_{4}$ TEGDME-LLZO electrolyte, it was found that Li-ion motion via TEGDME-related phase was preferred over filler or polymer matrix or polymer-filler interface [164]. In our opinion, a complete understanding on the conduction mechanism of such SPEs remain challenging as there are many influential factors behind it. Other than the abovementioned 
ceramic fillers, $\mathrm{Li}_{6.4} \mathrm{La}_{3} \mathrm{Zr}_{2} \mathrm{Al}_{0.2} \mathrm{O}_{12}$ and $\mathrm{LiSnZr}\left(\mathrm{PO}_{4}\right)_{3}$ have also been incorporated into PEO-LiTFSI [165] and PVDF-LiTFSI [166] electrolytes, respectively.

Another category of active fillers in CSPEs are the metal organic frameworks (MOFs) which display excellent properties such as microporous structures with high surface area, good mechanical and thermal properties, and controllable pore structure. MOFs have been credited to an increased lithium-ion transference number, ionic conductivity and improve the cycling stability of batteries [167]. Several examples of MOFs as active fillers in CSPEs for battery application include aluminum(III)-1,3,5-benzenetricarboxylate (Al-BTC) [168], D-UiO-66- $\mathrm{NH}_{2}$ [169], copper-1,4-benzenedicarboxylate (Cu-BDC) [170], HKUST-1(Cu) [171] and magnesium-benzene tricarboxylate (Mg-BTC) [172] to name a few. Overall, MOFs having 3D framework and controllable pore structures improve the interfacial contact between electrode and electrolyte. This is reflected with the addition of $\mathrm{Zn}_{4} \mathrm{O}$ (1,4-benzenedicarboxylate) in PEO-LiTFSI electrolyte which stabilized the interfacial resistance and improved the cyclability up to 100 cycles [173]. As usual, its ionic conductivity was enhanced too [173]. CSPE having Cu-BDC showed enhanced thermal stability which led to safer battery at high temperatures as compared to filler-free SPE [170]. More detailed reviews on CSPEs are available elsewhere [151,174-176]. Some other CSPEs systems that have been reported by many researchers are tabulated in Table 7 .

Table 7. Various SPEs systems with fillers added.

\begin{tabular}{|c|c|c|c|c|}
\hline Electrolyte System & $\begin{array}{l}\text { Preparation } \\
\text { Method }\end{array}$ & $\begin{array}{l}\text { Conductivity, } \sigma \\
\left(\mathrm{S} \mathrm{cm}^{-1}\right)\end{array}$ & Important Findings & Reference \\
\hline $\begin{array}{c}\mathrm{PEO}-\mathrm{LiCF} \mathrm{SO}_{3}-\mathrm{TiO}_{2} \\
{[\mathrm{EO}] /[\mathrm{Li}]=9: 1}\end{array}$ & Solution casting & $4.90 \times 10^{-5}\left(30^{\circ} \mathrm{C}\right)$ & $\begin{array}{c}E_{A}=0.82 \mathrm{eV} ; T_{g}=-46^{\circ} \mathrm{C} \\
T_{m}=60^{\circ} \mathrm{C}\end{array}$ & [43] \\
\hline $\begin{array}{c}\mathrm{PEO}-\mathrm{LiN}\left(\mathrm{CF}_{3} \mathrm{SO}_{2}\right)_{2-} \\
\mathrm{SiO}_{2} \\
{[\mathrm{EO}] /[\mathrm{Li}]=8: 1}\end{array}$ & Solution casting & $1.40 \times 10^{-4}$ & $\begin{array}{c}E_{A}=0.54 \mathrm{eV} ; T_{g}=-43^{\circ} \mathrm{C} \\
\text { Without filler: } \\
\sigma=1.50 \times 10^{-5} \mathrm{~S} \mathrm{~cm}^{-1}\left(27^{\circ} \mathrm{C}\right) \\
E_{A}=0.60 \mathrm{eV} ; T_{g}=-49^{\circ} \mathrm{C}\end{array}$ & [177] \\
\hline $\begin{array}{c}\mathrm{PEO}-\mathrm{LiClO}_{4}-\mathrm{SiO}_{2} \\
{[\mathrm{EO}] /[\mathrm{Li}]=8: 1}\end{array}$ & Solution casting & $2.50 \times 10^{-5}$ & $\begin{array}{c}E_{A}=0.55 \mathrm{eV} ; T_{g}=-44^{\circ} \mathrm{C} \\
\text { Without filler: } \\
\sigma=9.70 \times 10^{-7} \mathrm{~S} \mathrm{~cm}^{-1} ; T_{g}=-46^{\circ} \mathrm{C}\end{array}$ & [177] \\
\hline PEO-LiClO 4 -LLTO & Solution casting & $7.99 \times 10^{-4}\left(70{ }^{\circ} \mathrm{C}\right)$ & $\begin{array}{l}\text { LLTO nanoparticles was synthesized } \\
\text { via Pechini precursor method. } \\
\text { PCTB/SPE/Li cell }\left(60 \mathrm{~mA} \mathrm{~g}^{-1} ; 70^{\circ} \mathrm{C}\right) \text { : } \\
\text { Discharge capacity }=104 \mathrm{mAh}^{-1} \\
\text { 90\% capacity retention after } \\
\text { 300th cycle }\end{array}$ & [178] \\
\hline PEO-LiPF $6-\mathrm{EC}-\alpha \mathrm{CNT}$ & Solution casting & $1.30 \times 10^{-3}\left(25^{\circ} \mathrm{C}\right)$ & $\begin{array}{c}\alpha \mathrm{CNT} \text { was synthesized via } \\
\text { chemical route } \\
\text { Bandgap energy }=4.42 \mathrm{eV} \text { (indirect) } \\
\text { and } 4.60 \mathrm{eV} \text { (direct) }\end{array}$ & [103] \\
\hline $\begin{array}{l}\text { Chitosan- } \mathrm{LiClO}_{4}- \\
\text { glycerol-Ag } \\
\text { nanowires }\end{array}$ & Solution casting & $\sim 2.07 \times 10^{-5}\left(25^{\circ} \mathrm{C}\right)$ & $\begin{array}{l}\text { Diameter of Ag nanowires }=20 \mathrm{~nm} \\
\text { Elastic modulus }=\sim 3.5 \mathrm{MPa}\end{array}$ & [107] \\
\hline $\begin{array}{l}\text { Chitosan- } \mathrm{LiClO}_{4}- \\
\text { glycerol-Ag } \\
\text { nanospheres }\end{array}$ & Solution casting & $\sim 1.00 \times 10^{-4}\left(25^{\circ} \mathrm{C}\right)$ & $\begin{array}{c}\text { Diameter of Ag nanospheres }=100 \mathrm{~nm} \\
\text { Elastic modulus }=\sim 1.0 \mathrm{MPa}\end{array}$ & [107] \\
\hline
\end{tabular}


Table 7. Cont.

\begin{tabular}{|c|c|c|c|c|}
\hline Electrolyte System & $\begin{array}{l}\text { Preparation } \\
\text { Method }\end{array}$ & $\begin{array}{l}\text { Conductivity, } \sigma \\
\left(\mathrm{S} \mathrm{cm}^{-1}\right)\end{array}$ & Important Findings & Reference \\
\hline $\begin{array}{c}\text { PVA: PVP } \\
\text { (1:1)- } \mathrm{MgCl}_{2} \text {-CuS }\end{array}$ & Solution casting & $\begin{array}{c}3.32 \times 10^{-7}(\mathrm{RT}) \\
1.85 \times 10^{-3}(\text { protonic } \sigma \\
\text { at RT })\end{array}$ & $\begin{array}{l}\text { CuS nanoparticles (particle size } 20 \mathrm{~nm} \text { ) } \\
\text { was synthesized via microwave } \\
\text { irradiation method } \\
\text { More amorphous after CuS addition } \\
\text { Suitable for solid state magnesium } \\
\text { batteries, supercapacitors and PEMFC }\end{array}$ & [179] \\
\hline $\begin{array}{c}\text { PEO-PMMA } \\
\text { (1:1)-LiClO } 4-3 \text { wt. } \% \\
\quad \mathrm{SiO}_{2} \\
{[\mathrm{EO}+\mathrm{C}=\mathrm{O}] /[\mathrm{Li}]=9: 1}\end{array}$ & $\begin{array}{l}\text { Solution casting + } \\
\text { melt press }\end{array}$ & $0.51 \times 10^{-5}\left(27^{\circ} \mathrm{C}\right)$ & $\begin{array}{c}\mathrm{SiO}_{2} \text { particle size }<15 \mathrm{~nm} \\
E_{A}=0.32 \mathrm{eV} ; t_{L i+}=0.9894 \\
\text { Electrochemical stability } \\
\text { window } 6.18 \mathrm{~V} \\
\text { Without filler: } \\
\sigma=1.72 \times 10^{-5} \mathrm{~S} \mathrm{~cm}^{-1}\left(27^{\circ} \mathrm{C}\right) \\
E_{A}=0.37 \mathrm{eV}\end{array}$ & {$[180,181]$} \\
\hline $\begin{array}{c}\text { PEO-PMMA } \\
(1: 1)-\mathrm{LiClO}_{4}-3 \text { wt. } \% \\
\mathrm{Al}_{2} \mathrm{O}_{3} \\
{[\mathrm{EO}+\mathrm{C}=\mathrm{O}] /[\mathrm{Li}]=9: 1}\end{array}$ & $\begin{array}{l}\text { Solution casting + } \\
\text { melt press }\end{array}$ & $0.38 \times 10^{-5}\left(27^{\circ} \mathrm{C}\right)$ & $\begin{array}{c}\mathrm{Al}_{2} \mathrm{O}_{3} \text { particle size }<50 \mathrm{~nm} \\
E_{A}=0.30 \mathrm{eV} ; t_{L i+}=0.9836 \\
\text { Electrochemical stability } \\
\text { window } 6.00 \mathrm{~V}\end{array}$ & {$[180,181]$} \\
\hline $\begin{array}{c}\text { PEO-PMMA } \\
(1: 1)-\mathrm{LiClO}_{4}-3 \text { wt. } \% \\
\mathrm{ZnO} \\
{[\mathrm{EO}+\mathrm{C}=\mathrm{O}] /[\mathrm{Li}]=9: 1}\end{array}$ & $\begin{array}{l}\text { Solution casting + } \\
\text { melt press }\end{array}$ & $1.67 \times 10^{-5}\left(27^{\circ} \mathrm{C}\right)$ & $\begin{array}{l}\mathrm{ZnO} \text { particle size }<100 \mathrm{~nm} \\
E_{A}=0.27 \mathrm{eV} ; t_{L i+}=0.9857 \\
\text { Electrochemical stability } \\
\text { window } 6.06 \mathrm{~V}\end{array}$ & {$[180,181]$} \\
\hline $\begin{array}{c}\text { PEO-PMMA } \\
(1: 1)-\mathrm{LiClO}_{4}-3 \text { wt. } \% \\
\mathrm{SnO}_{2} \\
{[\mathrm{EO}+\mathrm{C}=\mathrm{O}] /[\mathrm{Li}]=9: 1}\end{array}$ & $\begin{array}{l}\text { Solution casting + } \\
\text { melt press }\end{array}$ & $1.00 \times 10^{-5}\left(27^{\circ} \mathrm{C}\right)$ & $\begin{array}{c}\mathrm{SnO}_{2} \text { particle size }=100 \mathrm{~nm} \\
E_{A}=0.38 \mathrm{eV} ; t_{L i+}=0.9881 \\
\text { Electrochemical stability } \\
\text { window } 6.10 \mathrm{~V}\end{array}$ & {$[180,181]$} \\
\hline $\begin{array}{c}\text { PEO-PMMA } \\
(1: 1)-\mathrm{LiClO}_{4}-10 \text { wt. } \% \\
\text { MMT } \\
{[\mathrm{EO}+\mathrm{C}=\mathrm{O}] /[\mathrm{Li}]=12: 1}\end{array}$ & $\begin{array}{l}\text { Microwave } \\
\text { irradiation }+ \\
\text { Solution casting } \\
\text { and melt press }\end{array}$ & $3.79 \times 10^{-6}\left(27^{\circ} \mathrm{C}\right)$ & $\begin{array}{l}\text { MMT is layered nanosheet which is } \\
\text { compatible with PEO polymer chain } \\
\text { Without filler: } \\
\qquad=1.99 \times 10^{-6} \mathrm{~S} \mathrm{~cm}^{-1}\left(27^{\circ} \mathrm{C}\right)\end{array}$ & [100] \\
\hline $\begin{array}{l}\text { PVDF-CA-LiTFSI- } \\
\text { OMMT }\end{array}$ & & $3.40 \times 10^{-4}\left(25^{\circ} \mathrm{C}\right)$ & $\begin{array}{c}E_{A}=0.45 \mathrm{eV} ; t_{\mathrm{Li+}}=0.315 \\
\text { Tensile strength }=44.89 \mathrm{MPa} \\
\text { Electrochemical stability } \\
\text { window } 4.20 \mathrm{~V} \\
\mathrm{LiFePO}_{4} / \mathrm{SPE} / \mathrm{Li}: \\
\text { Discharge capacity }=112.9 \mathrm{mAh} \mathrm{g}^{-1} \\
(0.5 \mathrm{C} ; 100 \text { th cycle }) \\
\text { Without filler: } \\
E_{A}=0.53 \mathrm{eV} ; t_{\mathrm{Li+}}=0.120 \\
\text { Tensile strength }=34.93 \mathrm{MPa}\end{array}$ & [182] \\
\hline $\begin{array}{c}\text { PEO-PMMA } \\
\text { (1:1)-LiBF } 4 \text {-EC-MMT } \\
\text { PEO-PMMA } \\
\text { (1:1)-LiBF }- \text {-EC-MMT }\end{array}$ & $\begin{array}{l}\text { Solution cast } \\
\text { method } \\
\text { ultrasonic- } \\
\text { microwave } \\
\text { irradiation solution } \\
\text { cast method }\end{array}$ & $\begin{array}{l}9.17 \times 10^{-6}\left(27^{\circ} \mathrm{C}\right) \\
6.43 \times 10^{-6}\left(27^{\circ} \mathrm{C}\right)\end{array}$ & $\begin{array}{l}\text { Ion-dipolar complexes intercalated in } \\
\text { MMT network in SPE prepared via } \\
\text { solution cast method. } \\
\text { Exfoliated MMT structure in SPE by } \\
\text { ultrasonic-microwave irradiation } \\
\text { solution cast method }\end{array}$ & [183] \\
\hline $\begin{array}{c}\text { PEO-LiCF } \mathrm{SO}_{3}-20 \mathrm{wt} . \% \\
\mathrm{Al}_{2} \mathrm{O}_{3}\end{array}$ & $\begin{array}{l}\text { Ball-milling and hot } \\
\text { press }\end{array}$ & $8.64 \times 10^{-5}(\mathrm{RT})$ & $T_{g}=-65.3^{\circ} \mathrm{C} ; \% \chi_{C}=18.6 \%$ & [38] \\
\hline
\end{tabular}


Table 7. Cont.

\begin{tabular}{|c|c|c|c|c|}
\hline Electrolyte System & $\begin{array}{l}\text { Preparation } \\
\text { Method }\end{array}$ & $\begin{array}{l}\text { Conductivity, } \sigma \\
\qquad\left(\mathrm{S} \mathrm{cm}^{-1}\right)\end{array}$ & Important Findings & Reference \\
\hline $\begin{array}{c}\text { PEO-LiCF } \mathrm{SO}_{3}-\mathrm{EC}-15 \\
\text { wt. } \% \mathrm{Al}_{2} \mathrm{O}_{3}\end{array}$ & Solution casting & $5.07 \times 10^{-4}\left(25^{\circ} \mathrm{C}\right)$ & $\begin{array}{c}T_{g}=-72.0^{\circ} \mathrm{C} ; \% \chi_{C}=31.1 \% \\
\text { Without filler: } \\
\sigma=8.12 \times 10^{-5} \mathrm{~S} \mathrm{~cm}^{-1}\left(25^{\circ} \mathrm{C}\right) \\
T_{g}=-70.5^{\circ} \mathrm{C} ; \% \chi_{C}=31.3 \%\end{array}$ & [120] \\
\hline $\begin{array}{c}\text { PMA:PEG } \\
\text { (65:35)- } \mathrm{NaClO}_{4} \text {-nano } \\
\alpha-\mathrm{Al}_{2} \mathrm{O}_{3}\end{array}$ & Solution casting & $1.76 \times 10^{-4}\left(70^{\circ} \mathrm{C}\right)$ & $\begin{array}{c}E_{A}=0.38 \mathrm{eV} \\
\text { Tensile strength }=50.79 \mathrm{MPa} \\
\text { Electrochemical stability } \\
\text { window } 4.50 \mathrm{~V} \\
\mathrm{Na}_{3} \mathrm{~V}_{2}\left(\mathrm{PO}_{4}\right)_{3} / \mathrm{SPE} / \mathrm{Na} \text { cell }(0.5 \mathrm{C}, \\
\left.70^{\circ} \mathrm{C}\right): \\
\text { Discharge capacity }=85 \mathrm{mAh} \mathrm{g}^{-1} \\
94.1 \% \text { capacity retention after } \\
350 \text { th cycle } \\
\text { Without filler: } \\
\sigma \text { around } 10^{-5} \mathrm{~S} \mathrm{~cm}^{-1}\left(70^{\circ} \mathrm{C}\right)\end{array}$ & [184] \\
\hline PEO-PVP-NaIO 4 -GO & Solution casting & $1.00 \times 10^{-6}\left(30^{\circ} \mathrm{C}\right)$ & $\begin{array}{c}\text { Without filler: } \\
\sigma=1.57 \times 10^{-7} \mathrm{~S} \mathrm{~cm}^{-1}\left(30^{\circ} \mathrm{C}\right)\end{array}$ & [185] \\
\hline $\begin{array}{c}\text { PEO-LiTFSI- } g-\mathrm{C}_{3} \mathrm{~N}_{4} \\
{[\mathrm{EO}] /[\mathrm{Li}]=20: 1}\end{array}$ & Solution casting & $\begin{array}{l}3.06 \times 10^{-5}\left(25^{\circ} \mathrm{C}\right) \\
2.50 \times 10^{-4}\left(60^{\circ} \mathrm{C}\right)\end{array}$ & $\begin{array}{c}\mathrm{g}-\mathrm{C}_{3} \mathrm{~N}_{4} \text { was synthesized via thermal } \\
\text { polycondensation route } \\
t_{L i+}=0.69 ; T_{g}=-41.1^{\circ} \mathrm{C} \\
\text { Tensile strength }=3.97 \mathrm{MPa} \\
\text { Electrochemical stability window } \\
5.12 \mathrm{~V} \text { at } 60^{\circ} \mathrm{C} \\
\mathrm{FeF}_{3} / \mathrm{SPE} / \mathrm{Li} \text { cell }\left(1 \mathrm{C}, 60^{\circ} \mathrm{C}\right): \\
\text { Capacity } 300 \mathrm{mAh} \mathrm{g}^{-1} \text { after } \\
200 \text { th cycle } \\
\text { Without g- } \mathrm{C}_{3} \mathrm{~N}_{4}: \\
\sigma=2.32 \times 10^{-6} \mathrm{~S} \mathrm{~cm}^{-1}\left(25^{\circ} \mathrm{C}\right) \\
t_{L i+}=0.25 ; T_{g}=-40.7^{\circ} \mathrm{C} \\
\text { Tensile strength }=0.92 \mathrm{MPa} \\
\text { Electrochemical stability window } \\
4.60 \mathrm{~V} \text { at } 60{ }^{\circ} \mathrm{C}\end{array}$ & [186] \\
\hline $\begin{array}{c}\text { PEO-LiTFSI- } \\
\mathrm{Li}_{10} \mathrm{GeP}_{2} \mathrm{~S}_{12} \\
{[\mathrm{EO}] /[\mathrm{Li}]=18: 1}\end{array}$ & Solution casting & $\begin{array}{l}1.18 \times 10^{-5}\left(25^{\circ} \mathrm{C}\right) \\
1.21 \times 10^{-3}\left(80^{\circ} \mathrm{C}\right)\end{array}$ & $\begin{array}{c}\left.\mathrm{Li}_{10} \mathrm{GeP}_{2} \mathrm{~S}_{12} \text { (particle size } 2-3 \mu \mathrm{m}\right) \\
\text { was synthesized via solid state } \\
\text { reaction method } \\
\mathrm{T}_{g}=-41.6^{\circ} \mathrm{C} ; \% \mathrm{XC}_{\mathrm{C}}=42.14 \% \\
t_{\mathrm{Li+}}=0.26\left(80^{\circ} \mathrm{C}\right) \\
\text { Electrochemical stability } \\
\text { window } 5.70 \mathrm{~V} \\
\mathrm{LiFePO}_{4} / \mathrm{SPE} / \mathrm{Li} \text { cell }\left(0.5 \mathrm{C}, 60^{\circ} \mathrm{C}\right): \\
\text { Discharge capacity }=137.4 \mathrm{mAh} \mathrm{g}^{-1} \\
92.5 \% \text { capacity retention after } \\
50 \text { th cycle } \\
\text { Without filler: } \\
\sigma=6.16 \times 10^{-6} \mathrm{~S} \mathrm{~cm}-1\left(25{ }^{\circ} \mathrm{C}\right) ; \\
=7.98 \times 10^{-4} \mathrm{~S} \mathrm{~cm}{ }^{-1}\left(80{ }^{\circ} \mathrm{C}\right) ; \\
T_{g}=-39.6^{\circ} \mathrm{C} ; \% \chi_{\mathrm{C}}=67.07 \% \\
t_{L i+}=0.22\left(80{ }^{\circ} \mathrm{C}\right) \\
\text { Electrochemical stability } \\
\text { window } 4.80 \mathrm{~V} \\
\text { Discharge capacity }=\sim 50 \mathrm{mAh} \mathrm{g}^{-1} \\
50.4 \% \text { capacity retention after } \\
50 \text { th cycle }\end{array}$ & [187] \\
\hline
\end{tabular}


Table 7. Cont.

\begin{tabular}{|c|c|c|c|c|}
\hline Electrolyte System & $\begin{array}{l}\text { Preparation } \\
\text { Method }\end{array}$ & $\begin{array}{l}\text { Conductivity, } \sigma \\
\left(\mathrm{S} \mathrm{cm}^{-1}\right)\end{array}$ & Important Findings & Reference \\
\hline $\begin{array}{c}\text { PVAc:PMMA } \\
\text { (70:30)-LiCl-TiO } 2\end{array}$ & Solution casting & $4.45 \times 10^{-4}\left(30^{\circ} \mathrm{C}\right)$ & $\begin{array}{c}T_{g}=28.1^{\circ} \mathrm{C} ; t_{+}=0.99 \\
D_{+}=7.07 \times 10^{-11} \mathrm{~cm}^{2} \mathrm{~s}^{-1} \\
\mu=2.71 \times 10^{-9} \mathrm{~cm}^{2} \mathrm{~V}^{-1} \mathrm{~s}^{-1} \\
n=2.35 \times 10^{22} \mathrm{~cm}^{-3} \\
\text { Electrochemical stability } \\
\text { window } 2.69 \mathrm{~V} \\
\text { Without filler: } \\
\sigma=1.03 \times 10^{-5} \mathrm{~S} \mathrm{~cm}^{-1}\left(30^{\circ} \mathrm{C}\right) \\
T_{g}=42.6^{\circ} \mathrm{C} ; t_{+}=0.97 \\
D_{+}=6.93 \times 10^{-11} \mathrm{~cm}^{2} \mathrm{~s}^{-1} \\
\mu=2.65 \times 10^{-9} \mathrm{~cm}^{2} \mathrm{~V}^{-1} \mathrm{~s}^{-1} \\
n=2.35 \times 10^{22} \mathrm{~cm}^{-3} \\
\text { Electrochemical stability } \\
\text { window } 1.69 \mathrm{~V}\end{array}$ & [99] \\
\hline $\begin{array}{l}\text { PEO-LiTFSI-Ni } 3_{3}^{-} \\
\quad(\text { BTC })_{2}\end{array}$ & Hot pressing & $1.40 \times 10^{-1}\left(30^{\circ} \mathrm{C}\right)$ & $\begin{array}{c}\mathrm{LiFePO}_{4} / \mathrm{SPE} / \mathrm{Li} \text { cell }(1 \mathrm{C}): \\
\text { Discharge capacity }=75 \mathrm{mAh} \mathrm{g}{ }^{-1}\end{array}$ & [188] \\
\hline
\end{tabular}

LLTO- $\mathrm{Li}_{0.3} \mathrm{La}_{0.566} \mathrm{TiO}_{3} ;$ PCTB—poly(2-chloro-3,5,6-trisulfide-1,4-benzoquinone); $\alpha \mathrm{CNT}$-amorphous carbon nanotubes; CuS-copper sulfate; $\mathrm{CA}$ —cellulose acetate; OMMT—organic modified montmorillonite; MMT—montmorillonite; $\mathrm{Al}_{2} \mathrm{O}_{3}$ —nano alumina; $\mathrm{NaIO}_{4}-$ sodium periodate; GO-graphene oxide; PMA—-poly(methacrylate); g- $\mathrm{C}_{3} \mathrm{~N}_{4}$ - polymeric graphitic carbon nitride; $\mathrm{Ni}_{3}-(\mathrm{BTC})_{2}-$ nickel-1,3,5benzene trcarboxxylate metal organic framework.

\subsubsection{SPEs Containing Other Kind of Additives}

It is an undeniable fact that ionic conductivity plays a crucial role in ensuring the performance of electrochemical cells, but the cationic transference number also influences the efficacy of devices in particular batteries. Enhancement in lithium-ion transference number has been observed in PEO-LiI SPEs upon the addition of calix [4] arene with values around 0.8 to 1 at elevated temperatures between 55 and $90{ }^{\circ} \mathrm{C}$ [189]. In most cases, the cationic transference number values are found to be below 0.4 without supramolecular additives in PEO-salt SPE systems as mentioned earlier. Based on ab initio computational work, Johansson [190] predicted that the cryptands, i.e., organic compounds having large $3 \mathrm{D}$ molecular structure, can trap anions, such as $\mathrm{Cl}^{-}, \mathrm{ClO}_{4}{ }^{-}, \mathrm{BF}_{4}{ }^{-}$and $\mathrm{F}^{-}$, and form coordination complexes, thereby reducing their tendency to re-associate with $\mathrm{Li}^{+}$cation and consequently increasing the cationic transference number. However, the supramolecular compounds are unable to confine large $\mathrm{PF}_{6}{ }^{-}, \mathrm{TFSI}^{-}$or $\left[\left(\mathrm{CF}_{3} \mathrm{SO}_{2}\right)_{2} \mathrm{~N}\right]^{-}$anions within a $3 \mathrm{D}$ network and cannot form complexes [190].

Mazor et al. [191] investigated the influence of calix[6]pyrrole on $\mathrm{PEO}-\mathrm{LiCF}_{3} \mathrm{SO}_{3} \mathrm{SPEs}$. Although the ambient conductivity was found to decrease with the addition of calix, the conductivity at $60{ }^{\circ} \mathrm{C}$ was higher than that without calix. Nevertheless, the $t_{L i+}$ of the calix-added SPE enhanced by $185 \%$ to 0.74 from 0.26 of the calix-free SPE at $60{ }^{\circ} \mathrm{C}$ [191]. Ambient conductivity decrement is said to be attributed to the increased rigidity of polymer network, whereas an improvement in lithium-ion transference number is due to increased amount of free ions from dissociated ion aggregates. The SPE has been employed in $\mathrm{Li} / \mathrm{MoO}_{\mathrm{x}} \mathrm{S}_{\mathrm{y}}$ cells that exhibited a power level of $2.1 \mathrm{~mW} \mathrm{~cm}{ }^{-2}$ at $90{ }^{\circ} \mathrm{C}$ and a discharge capacity of $\sim 24 \mu \mathrm{Ah}$ on the 60th cycle [191]. It is said that calix[6]arene can minimize the growth of lithium dendrites and subsequently improves cell performance [192]. A similar observation wherein an increased lithium-ion transference number $\left(t_{L i+}=0.95\right.$ at $70{ }^{\circ} \mathrm{C}$ ) was accompanied by conductivity decrement has been reported in PEO-LiBF calix[6]pyrrole system [193]. In addition, the lithium diffusion-coefficient values were $2.0 \times 10^{-7} \mathrm{~cm}^{2} \mathrm{~s}^{-1}$ and $2.5 \times 10^{-7} \mathrm{~cm}^{2} \mathrm{~s}^{-1}$ for calix-free and calix-incorporated PEO-based electrolytes, respectively [193].

As aforementioned, the incorporation of supramolecular additives, such as calix-based compounds, is used to increase cationic transference number by trapping/immobilizing 
anion of the salt [194]. Usually, this will lead to reduce the anionic mobility and unwittingly decrease the ionic conductivity, as stated in preceding paragraph. Nevertheless, there are some controversial reports that showed otherwise. Won and co-workers [195] observed that the SPE containing PVC doped with lithium chloride ( $\mathrm{LiCl})$ salt and calix[4]pyrrole exhibited higher ionic conductivity, at around $10^{-3} \mathrm{~S} \mathrm{~cm}^{-1}$ at $25^{\circ} \mathrm{C}$, compared to that calixfree SPE $\left(10^{-5} \mathrm{~S} \mathrm{~cm}^{-1}\right)$. Using density functional theory, they obtained that the dissociation energies for LiCl-calix and PVC-LiCl-calix complexes were 110.8 and $-18.1 \mathrm{kcal} \mathrm{mol}^{-1}$, whereas, for $\mathrm{LiCl}$ salt, the dissociation energy value was $145.6 \mathrm{kcal} \mathrm{mol}^{-1}$ [195]. A lower dissociation energy value implies that the cation of salt is more free to move, while its anion has complexed with calix [195].

Plastic crystal SN has also been employed as a polymer matrix in electrolyte, besides serving as a plasticizer and ionizer for both Li- and Na-based salts $[131,196]$. In order to improve the transference number of $\mathrm{Na}^{+}$, Chen et al. [196] synthesized boroncontaining 2-hydroxyethyl methacrylate (B-HEMA) before incorporating it into SN-based polymer electrolyte that had non-woven polypropylene-cellulose composite framework and $\mathrm{NaClO}_{4}$ salt. This electrolyte having $\mathrm{B}^{-}$(boron anion) acceptor was prepared via a UV-assisted curing method, using 2-hydroxy-2-methyl-1-phenyl-1-propanone as photoinitiator. This electrolyte demonstrated superior properties in terms of ambient conductivity $\left(3.60 \times 10^{-4} \mathrm{~S} \mathrm{~cm}^{-1}\right)$, tensile strength $(28.2 \mathrm{MPa})$ and $\mathrm{Na}^{+}$transference number of $\left(t_{\mathrm{Na+}}=0.62\right)$ [196]. Promising results were also obtained after applying the electrolyte in Na-ion batteries (initial capacity of $\sim 105 \mathrm{mAh} \mathrm{g}^{-1}$ at $0.1 \mathrm{C}$ and retaining $80 \%$ capacity after 120 cycles) [196]. The boron moiety is said to complex with $\mathrm{ClO}_{4}{ }^{-}$ion of the salt, thus lowering the anionic mobility and subsequently enhancing the $\mathrm{Na}^{+}$ion transference number. Meanwhile, the authors have stated that the polypropylene-cellulose structure did not contribute in ionic conduction, but instead improved the mechanical property of the plastic crystal polymer electrolyte [196].

Polyaniline (PANI), which is a conducting polymer that is usually used as counter electrode in DSSCs $[197,198]$, has been incorporated in SPE containing PEO, tetrapropylammonium iodide (TPAI) and $\mathrm{I}_{2}$ to trap the large cations $\left(\left(\mathrm{C}_{3} \mathrm{H}_{7}\right)_{4} \mathrm{~N}^{+}\right.$or simply TPA $\left.{ }^{+}\right)$ so that the anions can contribute more to conduction, which is beneficial in DSSC [199]. The authors also believed that PANI has performed the role of plasticizing agent in decreasing crystallinity of PEO and its melting point based on DSC analysis. Upon PANI addition, the degrees of crystallinity and $T_{m}$ were reduced to $3.37 \%$ and $66.2{ }^{\circ} \mathrm{C}$ from $8.93 \%$ and $66.5^{\circ} \mathrm{C}$ [199]. The PANI-added SPE attained higher values of room temperature conductivity $\left(8.61 \times 10^{-5} \mathrm{~S} \mathrm{~cm}^{-1}\right)$ and ionic transference number $(0.99)$ than PANI-free SPE $\left(\sigma=6.81 \times 10^{-5} \mathrm{~S} \mathrm{~cm}^{-1} ; t_{i o n}=0.96\right)$. The former also gave better DSSC performance (5.01\% efficiency) than the latter (efficiency 3.5\%) [199].

A special additive, i.e., hydroxypropyl trimethylammonium bis(trifluoromethane) sulfonamide chitosan salt (HACC-TFSI), was synthesized via ion-exchange route, using hydroxypropyl trimethylammonium chloride chitosan salt and LiTFSI before HACCTFSI, PEO and LiTFSI were mixed in DMF solvent to form SPE via the solution-casting technique [200]. Ionic conductivity values for HACC-TFSI-added PEO electrolyte at 30 and $60{ }^{\circ} \mathrm{C}$ were $1.77 \times 10^{-5} \mathrm{~S} \mathrm{~cm}^{-1}$ and $5.01 \times 10^{-4} \mathrm{~S} \mathrm{~cm}^{-1}$, respectively [200]. In contrast, conductivities of $3.80 \times 10^{-6} \mathrm{~S} \mathrm{~cm}^{-1}$ and $1.90 \times 10^{-4} \mathrm{~S} \mathrm{~cm}^{-1}$ were recorded at the same temperature by PEO SPE without HACC-TFSI [200]. Besides better conductivity, $\mathrm{Li}^{+}$ion transference number and tensile strength increased by 1.7 and 3.6 times. Moreover, the SPE with HACC-TFSI was found to be resistant against elevated temperature $\left(150^{\circ} \mathrm{C}\right)$ by retaining its shape after exposure at high temperature for one hour [200]. On the contrary, the electrolyte without HACC-TFSI has melted under similar conditions. $\mathrm{LiFePO}_{4} / \mathrm{Li}$ cell with HACC-TFSI added SPE demonstrated good cyclability and stability over 100 cycles maintaining $73 \%$ capacity of its initial capacity of $\sim 108 \mathrm{mAh} \mathrm{g}^{-1}$ [200]. It is worthy to mention that this is considered quite an achievement, since there are not many cells with SPEs that can withstand and operate under such a high temperature. 


\section{Summary and Outlook}

Solid-state electrochemical devices are the focus for the next-generation energy sources, especially for large power-consumption machines, such as electric vehicles. SPEs in electrochemical devices offer flexibility, low cost, harmless and cell cycling improvement. Basic SPEs which contain polymer and salt typically exhibit the ambient ionic conductivity of $\sim 10^{-5} \mathrm{~S} \mathrm{~cm}^{-1}$. The conductivity must be improved at least to $10^{-3} \mathrm{~S} \mathrm{~cm}^{-1}$ for application in devices. Additives such as plasticizers and fillers are able to improve the conductivity of the SPEs. Plasticizers are able to reduce the crystallinity of the SPEs and enhance the elasticity and the segmental motion of the polymer chain, leading to an increase the overall ionic conductivity. Fillers, on the other hand, contribute either directly (active) or indirectly (inactive) towards conductivity enhancement. In contrast to SPEs with the plasticizers, fillers are able to improve the mechanical strength of the SPEs. Blending polymers is another approach that is used specially to improve the mechanical strength, apart from conductivity enhancement. Although ionic conductivity is one significant factor determining the feasibility of SPEs in electrochemical devices, other factors, such as ionic transport and transference number of ions, also influence the performance. It is appreciable that various efforts have been undertaken in developing suitable SPEs for practical use in electrochemical devices. In our opinion, there is a promising future for SPEs to compete and substitute liquid electrolytes in electrochemical devices. Among the abovementioned approaches, we think that there is much room for developments and improvements on SPEs having active fillers, in particular, MOFs, since research on this is relatively new and less than the others. Moreover, so far, the research only focuses on MOF-containing SPEs in application for Li-ion batteries. We believe that SPEs containing MOFs as fillers have the potential to be applied in other electrochemical devices, including Li-air batteries, DSSCs, PEMFCs and supercapacitors.

Author Contributions: Conceptualization, L.P.T. and M.H.B.; validation, A.K.A.; formal analysis, L.P.T. and M.H.B.; writing-original draft preparation, L.P.T. and M.H.B.; writing-review and editing, A.K.A.; supervision, A.K.A.; funding acquisition, M.H.B. All authors have read and agreed to the published version of the manuscript.

Funding: This research received no external funding.

Institutional Review Board Statement: Not applicable.

Informed Consent Statement: Not applicable.

Data Availability Statement: Not applicable.

Acknowledgments: M.H. Buraidah would like to thank Malaysia Ministry of Higher Education for the FRGS grant (No. FRGS/1/2019/STG07/UM/02/3).

Conflicts of Interest: The authors declare no conflict of interest.

\section{References}

1. Fenton, D.E.; Parker, J.M.; Wright, P.V. Complexes of alkali metal ions with poly (ethylene oxide). Polymer 1973, 14, 589. [CrossRef]

2. Armand, M.B.; Gabano, J.M.; Duclot, M. Second International Meeting on Solid Electrolytes, St. Andrews, Scotland, UK, 20-22 September 1978; Extended Abstract No. 6.5 in Fast Ion Transport in, Solids; Vashista, P., Mundy, J.N., Shenoy, G.K., Eds.; Elsevier: Amsterdam, North Holland, The Netherlands, 1979; p. 131.

3. Voropaeva, D.Y.; Novikova, S.A.; Yaroslavtsev, A.B. Polymer electrolytes for metal-ion batteries. Russ. Chem. Rev. 2020, 89, 1132-1155. [CrossRef]

4. Wu, H.; Wick, C.D. Computational Investigation on the Role of Plasticizers on Ion Conductivity in Poly(ethylene Oxide) LiTFSI Electrolytes. Macromolecules 2010, 43, 3502-3510. [CrossRef]

5. Webb, M.A.; Savoie, B.M.; Wang, Z.-G.; Miller III, T.F. Chemically Specific Dynamic Bond Percolation Model for Ion Transport in Polymer Electrolytes. Macromolecules 2015, 48, 7346-7358. [CrossRef]

6. Duarte, P.; Pereira, S.; Cunha, I.; Pimentel, A.; Dionísio, M.; Fortunato, E.; Martins, R.; Pereira, L. Cellulose-based solid electrolyte membranes through microwave assisted regeneration and application in electrochromic displays. Front. Mater. 2020, 7, 269. [CrossRef] 
7. Wu, Y.; Li, Y.; Wang, Y.; Liu, Q.; Chen, Q.; Chen, M. Advances and prospects of PVDF based polymer electrolytes. J. Energy Chem. 2022, 64, 62-84. [CrossRef]

8. Arof, A.K.; Naeem, M.; Hameed, F.; Jayasundara, W.J.M.J.S.R.; Careem, M.A.; Teo, L.P.; Buraidah, M.H. Quasi solid state dye-sensitized solar cells based on polyvinyl alcohol (PVA) electrolytes containing $\mathrm{I}^{-} / \mathrm{I}_{3}{ }^{-}$redox couple. Opt. Quant. Electron. 2014, 46, 143-154. [CrossRef]

9. Arof, A.K.; Amirudin, S.; Yusof, S.Z.; Noor, I.M. A method based on impedance spectroscopy to determine transport properties of polymer electrolytes. Phys. Chem. Chem. Phys. 2014, 16, 1856-1867. [CrossRef]

10. Buraidah, M.H.; Teo, L.P.; Majid, S.R.; Arof, A.K. Ionic conductivity by correlated barrier hopping in $\mathrm{NH}_{4} \mathrm{I}$ doped chitosan solid electrolyte. Phys. B 2009, 404, 1373-1379. [CrossRef]

11. Kurapati, S.; Gunturi, S.S.; Nadella, K.J.; Erothu, H. Novel solid polymer electrolyte based on PMMA:CH $\mathrm{COOLi}_{3} \mathrm{effect}$ of salt concentration on optical and conductivity studies. Polym. Bull. 2019, 76, 5463-5481. [CrossRef]

12. Teoh, K.H.; Lim, C.-S.; Ramesh, S. Lithium ion conduction in corn starch based solid polymer electrolytes. Measurement 2014, 48, 87-95. [CrossRef]

13. Li, J.; Zhu, L.; Zhang, J.; Jing, M.; Yao, S.; Shen, X.; Li, S.; Tu, F. Approaching high performance PVDF-HFP based solid composite electrolytes with LLTO nanorods for solid-state lithium-ion batteries. Int. J. Energy Res. 2021, 45, 7663-7674. [CrossRef]

14. Golodnitsky, D.; Strauss, E.; Peled, E.; Greenbaum, S. Review-On order and disorder in polymer electrolytes. J. Electrochem. Soc. 2015, 162, A2551-A2566. [CrossRef]

15. Noor, I.M. Determination of charge carrier transport properties of gellan gum-lithium triflate solid polymer electrolyte from vibrational spectroscopy. High Perform. Polym. 2020, 32, 168-174. [CrossRef]

16. Ahmed, H.T.; Abdullah, O.G. Impedance and ionic transport properties of proton-conducting electrolytes based on polyethylene oxide/methylcellulose blend polymers. J. Sci.-Adv. Mater. Dev. 2020, 5, 125-133. [CrossRef]

17. Iftikhar, H.; Sonai, G.G.; Hashmi, S.G.; Nogueira, A.F.; Lund, P.D. Progress on electrolytes development in dye-sensitized solar cells. Materials 2019, 12, 1998. [CrossRef] [PubMed]

18. Aziz, S.B.; Brza, M.A.; Brevik, I.; Hafiz, M.H.; Asnawi, A.S.F.M.; Yusof, Y.M.; Abdulwahid, R.T.; Kadir, M.F.Z. Blending and Characteristics of Electrochemical Double-Layer Capacitor Device Assembled from Plasticized Proton Ion Conducting Chitosan:Dextran: $\mathrm{NH}_{4} \mathrm{PF}_{6}$ Polymer Electrolytes. Polymers 2020, 12, 2103. [CrossRef] [PubMed]

19. Stephan, A.M. Review on gel polymer electrolytes for lithium batteries. Eur. Polym. J. 2006, 42, 21-42. [CrossRef]

20. Stallworth, P.E.; Li, J.; Greenbaum, S.G.; Croce, F.; Slane, S.; Salomon, M. Sodium-23 NMR and complex impedance studies of gel electrolytes based on poly(acrylonitrile). Solid State Ion. 1994, 73, 119-126. [CrossRef]

21. Lewandowska, K. Miscibility and thermal stability of poly(vinyl alcohol)/chitosan mixtures. Thermochim. Acta 2009, 493, 42-48. [CrossRef]

22. Gómez-Carracedo, A.; Alvarez-Lorenzo, C.; Gómez-Amoza, J.L.; Concheiro, A. Chemical structure and glass transition temperature of non-ionic cellulose ethers. J. Therm. Anal. Calorim. 2003, 73, 587-596. [CrossRef]

23. Sivakumar, M.; Subadevi, R.; Rajendran, S.; Wu, H.-C.; Wu, N.-L. Compositional effect of PVdF-PEMA blend gel polymer electrolytes for lithium polymer batteries. Eur. Polym. J. 2007, 43, 4466-4473. [CrossRef]

24. Sakurai, K.; Maegawa, T.; Takahashi, T. Glass transition temperature of chitosan and miscibility of chitosan/poly(N-vinyl pyrrolidone) blends. Polymer 2000, 41, 7051-7056. [CrossRef]

25. Lu, D.R.; Xiao, C.M.; Xu, S.J. Starch-based completely biodegradable polymer materials. EXPRESS Polym. Lett. 2009, 3, 366-375. [CrossRef]

26. Ue, M. Secondary batteries—Lithium rechargeable systems. Electrolytes: Nonaqueous. Encylcopedia Electrochem. Power Sources 2009, 71-84.

27. Arof, A.K.; Teo, L.P.; Yahya, R. Ionic conductivity in some chitosan-based polymer electrolytes. Curr. Trends Polym. Sci. 2010, 14, $29-44$.

28. Izutsu, K. Electrochemistry in Nonaqueous Solutions; Wiley-VCH: Weinheim, Germany, 2002; pp. 3-24.

29. Yu, Z.; Vlachopoulos, N.; Gorlov, M.; Kloo, L. Liquid electrolytes for dye-sensitized solar cells. Dalton Trans. 2011, 40, 10289-10303. [CrossRef]

30. Fawcett, W.R. Acidity and Basicity Scales for Polar Solvents. J. Phys. Chem. 1993, 97, 9540-9546. [CrossRef]

31. Solangi, M.Y.; Aftab, U.; Ishaque, M.; Bhutto, A.; Nafady, A.; Ibupoto, Z.H. Polyvinyl fibers as outperform candidature in the solid polymer electrolytes. J. Ind. Text. 2020, 1-13. [CrossRef]

32. Vijayakumar, G.; Karthick, S.N.; Subramania, A. A new class of P(VdF-HFP)-CeO $-\mathrm{LiClO}_{4}$ based composite microporous membrane electrolytes for Li-ion batteries. Int. J. Electrochem. 2011, 2011, 926383. [CrossRef]

33. Röchow, E.T.; Coeler, M.; Pospiech, D.; Kobsch, O.; Mechtaeva, E.; Vogel, R.; Voit, B.; Nikolowski, K.; Wolter, M. In situ preparation of crosslinked polymer electrolytes for lithium ion batteries: A comparison of monomer systems. Polymers 2020, $12,1707$. [CrossRef]

34. Liu, L.; Wang, Z.; Zhao, Z.; Zhao, Y.; Li, F.; Yang, L. PVDF/PAN/SiO 2 polymer electrolyte membrane prepared by combination of phase inversion and chemical reaction method for lithium ion batteries. J. Solid State Electrochem. 2016, 20, 699-712. [CrossRef]

35. Eriksson, T.; Mace, A.; Manabe, Y.; Yoshizawa-Fujita, M.; Inokuma, Y.; Brandell, D.; Jonas, M. Polyketones as Host Materials for Solid Polymer Electrolytes. J. Electrochem. Soc. 2020, 167, 070537. [CrossRef] 
36. Gupta, S.; Singh, P.K.; Bhattacharya, B. Charge carriers dynamics in PEO + NaSCN polymer electrolytes. Ionics 2018, 24, 163-167. [CrossRef]

37. Ma, Q.; Liu, J.; Qi, X.; Rong, X.; Shao, Y.; Feng, W.; Nie, J.; Hu, Y.; Li, H.; Huang, X.; et al. New Na[(FSO $\left.\left.\mathrm{F}_{2}\right)\left(\mathrm{n}_{-} \mathrm{C}_{4} \mathrm{~F}_{9} \mathrm{SO}_{2}\right) \mathrm{N}\right]-\mathrm{Based}$ Polymer Electrolyte for Solid-State Sodium Batteries. J. Mater. Chem. A 2017, 5, 7738-7743. [CrossRef]

38. Klongkan, S.; Pumchusak, J. Effects of Nano Alumina and Plasticizers on Morphology, Ionic Conductivity, Thermal and Mechanical Properties of PEO-LiCF $\mathrm{SO}_{3}$ Solid Polymer Electrolyte. Electrochim. Acta 2015, 161, 171-176. [CrossRef]

39. Sim, L.N.; Sentanin, F.C.; Pawlicka, A.; Yahya, R.; Arof, A.K. Development of polyacrylonitrile-based polymer electrolytes incorporated with lithium bis(trifluoromethane)sulfonimide for application in electrochromic device. Electrochim. Acta 2017, 229, 22-30. [CrossRef]

40. Sohaimy, M.I.H.A.; Isa, M.I.N. Natural Inspired Carboxymethyl Cellulose (CMC) Doped with Ammonium Carbonate (AC) as Biopolymer Electrolyte. Polymers 2020, 12, 2487. [CrossRef]

41. Baharun, N.N.S.; Mingsukang, M.A.; Buraidah, M.H.; Woo, H.J.; Teo, L.P.; Arof, A.K. Development of solid polymer electrolytes based on sodium-carboxymethylcellulose ( $\mathrm{NaCMC}$ )-polysulphide for quantum dot-sensitized solar cells (QDSSCs). Ionics 2020, 26, 1365-1378. [CrossRef]

42. Perumal, P.; Selvasekarapandian, S.; Abhilash, K.P.; Sivaraj, P.; Hemalatha, R.; Selvin, P.C. Impact of lithium chlorate salts on structural and electrical properties of natural polymer electrolytes for all solid state lithium polymer batteries. Vacuum 2018, 159, 277-281. [CrossRef]

43. Vignarooban, K.; Dissanayake, M.A.K.L.; Albinsson, I.; Mellander, B.-E. Effect of $\mathrm{TiO}_{2}$ nano-filler and EC plasticizer on electrical and thermal properties of poly(ethylene oxide) (PEO) based solid polymer electrolytes. Solid State Ion. 2014, 266, 25-28. [CrossRef]

44. Singh, R.; Baghel, J.; Shukla, S.; Bhattacharya, B.; Rhee, H.-W.; Singh, P.K. Detailed electrical measurements on sago starch biopolymer solid electrolyte. Phase Transit. 2014, 87, 1237-1245. [CrossRef]

45. Singh, R.; Singh, P.K.; Tomar, S.K.; Bhattacharya, B. Synthesis, characterization, and dye-sensitized solar cell fabrication using solid biopolymer electrolyte membranes. High Perform. Polym. 2016, 28, 47-54. [CrossRef]

46. Hassan, M.F.; Azimi, N.S.N.; Kamarudin, K.H.; Sheng, C.K. Solid Polymer Electrolytes Based on Starch-Magnesium Sulphate: Study on Morphology and Electrical Conductivity. ASM Sci. J. 2018, 1, 17-28.

47. Singh, V.K.; Bhattacharya, B.; Shukla, S.; Singh, P.K. Dye-sensitized solar cell comprising polyethyl methacrylate doped with ammonium iodide solid polymer electrolyte. Appl. Phys. A 2015, 118, 877-883. [CrossRef]

48. Whba, R.A.G.; TianKhoon, L.; Su'ait, M.S.; Rahman, M.Y.A.; Ahmad, A. Influence of binary lithium salts on $49 \%$ poly (methyl methacrylate) grafted natural rubber based solid polymer electrolytes. Arab. J. Chem. 2020, 13, 3351-3361. [CrossRef]

49. Ramesh, S.; Arof, A.K. Electrical conductivity studies of polyvinyl chloride-based electrolytes with double salt system. Solid State Ion. 2000, 136-137, 1197-1200. [CrossRef]

50. Tao, R.; Fujinami, T. Application of mix-salts composed of lithium borate and lithium aluminate in PEO-based polymer electrolytes. J. Power Sources 2005, 146, 407-411. [CrossRef]

51. Yang, H.; Farrington, G.C. Poly(ethylene oxide) electrolytes containing mixed salts. J. Polym. Sci. B Polym. Phys. 1993, 31, 157-163. [CrossRef]

52. Moryoussef, A.; Bonat, M.; Fouletier, M.; Hicter, P. Proceedings, 6th Riso International Symposium on Metallurgy and Materials Science; Poulsen, F.W., Andersen, N.H., Clausen, K., Skaarup, S., Sorensen, O.T., Eds.; Riso National Lab.: Roskilde, Denmark, 1985 ; p. 335.

53. Henderson, W.A.; Passerini, S.; Smyrl, W.H. Lithium Batteries: Proceedings of the International Symposium (Eds. S. Surampudi, R.A. Marsh, Z. Ogumi, J. Prakash), Mixed Salt Polymer Electrolytes- $\mathrm{PEO}_{n}(x) \mathrm{LiCF}_{3} \mathrm{SO}_{3}(1-x) \mathrm{LiClO}_{4}(n=12)$, Electrochemical Society Proceedings; The Electrochemical Society: Pennington, NJ, USA, 2000; Volume 99-25, pp. 515-523.

54. Deepa, M.; Sharma, N.; Agnihotry, S.A.; Chandra, R.; Sekhon, S.S. Effect of mixed salts on the properties of gel polymeric electrolytes. Solid State Ion. 2002, 148, 451-455. [CrossRef]

55. Giua, M.; Panero, S.; Scrosati, B.; Cao, X.; Greenbaum, S.G. Investigation of mixed cation effects in $\mathrm{PEO}_{9} \mathrm{Zn}_{1-\mathrm{x}} \mathrm{Cu}_{\mathrm{x}}\left(\mathrm{CF}_{3} \mathrm{SO}_{3}\right)_{2}$ polymer electrolytes. Solid State Ion. 1996, 83, 73-78. [CrossRef]

56. Dissanayake, M.A.K.L.; Jaseetharan, T.; Senadeera, G.K.R.; Mellander, B.-E.; Albinsson, I.; Furlani, M.; Kumari, J.M.K.W. Solidstate solar cells co-sensitized with PbS/CdS quantum dots and N719 dye and based on solid polymer electrolyte with binary cations and nanofillers. J. Photochem. Photobio. A Chem. 2021, 405, 112915. [CrossRef]

57. Zhao, Q.; Chen, P.; Li, S.; Liu, X.; Archer, L.A. Solid-state Polymer Electrolytes Stabilized by Task-specific Salt Additives. J. Mater. Chem. A 2019, 7, 7823-7830. [CrossRef]

58. Aziz, N.A.; Majid, S.R.; Arof, A.K. Synthesis and characterizations of phthaloyl chitosan-based polymer electrolytes. J. Non. Cryst. Solids 2012, 358, 1581-1590. [CrossRef]

59. Romanazzi, G.; Gabler, F.M.; Margosan, D.; Mackey, B.E.; Smilanick, J.L. Effect of chitosan dissolved in different acids on its ability to control postharvest gray mold of table grape. Phytopathology 2009, 99, 1028-1036. [CrossRef] [PubMed]

60. Demarger-Andre, S.; Domard, A. Chitosan carboxylic acid salts in solution and in the solid state. Carbohydr. Polym. 1994, 23, 211-219. [CrossRef]

61. Kurita, K.; Ikeda, H.; Shimojoh, M.; Yang, J. N-Phthaloylated chitosan as an essential precursor for controlled chemical modifications of chitosan: Synthesis and evaluation. Polym. J. 2007, 39, 945-952. [CrossRef]

62. Yoksan, R.; Akashi, M.; Biramontri, S.; Chirachanchai, S. Hydrophobic chain conjugation at hydroxyl group onto $\gamma$-ray irradiated chitosan. Biomacromolecules 2001, 2, 1038-1044. [CrossRef] 
63. Rahman, N.A.; Hanifah, S.A.; Mobarak, N.N.; Su'ait, M.S.; Ahmad, A.; Loh, K.S.; Lee, T.K. Synthesis and characterizations of o-nitrochitosan based biopolymer electrolyte for electrochemical devices. PLoS ONE 2019, 14, e0212066. [CrossRef]

64. Jing, B.; Wang, X.; Shi, Y.; Zhu, Y.; Gao, H.; Fullerton-Shirey, S.K. Combining Hyperbranched and Linear Structures in Solid Polymer Electrolytes to Enhance Mechanical Properties and Room-Temperature Ion Transport. Front. Chem. 2021, 9, 563864. [CrossRef]

65. Imperiyka, M.; Ahmad, A.; Hanifah, S.A.; Rahman, M.Y.A. Preparation and Characterization of Polymer Electrolyte of Glycidyl Methacrylate-Methyl Methacrylate- $\mathrm{LiClO}_{4}$ Plasticized with Ethylene Carbonate. Int. J. Polym. Sci. 2014, 2014, 63879. [CrossRef]

66. Lehmann, M.L.; Yang, G.; Nanda, J.; Saito, T. Well-designed Crosslinked Polymer Electrolyte Enables High Ionic Conductivity and Enhanced Salt Solvation. J. Electrochem. Soc. 2020, 167, 070539. [CrossRef]

67. Youcef, H.B.; Garcia-Calvo, O.; Lago, N.; Shanmukaraj, D.; Armand, M. Cross-Linked Solid Polymer Electrolyte for All-Solid-State Rechargeable Lithium Batteries. Electrochim. Acta 2016, 220, 587-594. [CrossRef]

68. Porcarelli, L.; Gerbaldi, C.; Bella, F.; Nair, J.R. Super Soft All-Ethylene Oxide Polymer Electrolyte for Safe All Solid Lithium Batteries. Sci. Rep. 2016, 6, 19892. [CrossRef]

69. Li, S.; Zuo, C.; Jo, Y.H.; Li, S.; Jiang, K.; Yu, L.; Zhang, Y.; Wang, J.; Li, L.; Xue, Z. Enhanced ionic conductivity and mechanical properties via dynamic-covalent boroxine bonds in solid polymer electrolytes. J. Membr. Sci. 2020, 608, 118218. [CrossRef]

70. Lim, J.Y.; Kang, D.A.; Kim, N.U.; Lee, J.M.; Kim, J.H. Bicontinuously crosslinked polymer electrolyte membranes with high ion conductivity and mechanical strength. J. Membr. Sci. 2019, 589, 117250. [CrossRef]

71. Vijayalekshmi, V.; Khastgir, D. Eco-friendly methanesulfonic acid and sodium salt of dodecylbenzene sulfonic acid doped cross-linked chitosan based green polymer electrolyte membranes for fuel cell applications. J. Membr. Sci. 2017, 523, 45-59. [CrossRef]

72. Su'ait, M.S.; Ahmad, A.; Hamzah, H.; Rahman, M.Y.A. Preparation and characterization of PMMA-MG49-LiClO 4 solid polymer electrolyte. J. Phys. D Appl. Phys. 2009, 42, 055410. [CrossRef]

73. Su'ait, M.S.; Ahmad, A.; Hamzah, H.; Rahman, M.Y.A. Effect of lithium salt concentrations on blended $49 \%$ poly(methyl methacrylate) grafted natural rubber and poly(methyl methacrylate) based solid polymer electrolyte. Electrochim. Acta 2011, 57, 123-131. [CrossRef]

74. Ali, A.M.M.; Subban, R.H.Y.; Bahron, H.; Yahya, M.Z.A.; Kamisan, A.S. Investigation on modified natural rubber gel polymer electrolytes for lithium polymer battery. J. Power Sources 2013, 244, 636-640. [CrossRef]

75. Sutton, P.; Airoldi, M.; Porcarelli, L.; Olmedo-Martínez, J.L.; Mugemana, C.; Bruns, N.; Mecerreyes, D.; Ullrich, S.; Gunkel, I. Tuning the Properties of a UV-Polymerized, Cross-Linked Solid Polymer Electrolyte for Lithium Batteries. Polymers 2020, 12, 595. [CrossRef]

76. Raghu, S.; Kilarkaje, S.; Sanjeev, G.; Nagaraja, G.K.; Devendrappa, H. Effect of electron beam irradiation on polymer electrolytes: Change in morphology, crystallinity, dielectric constant and AC conductivity with dose. Radiat. Phys. Chem. 2014, 98, 124-131. [CrossRef]

77. Singh, D.; Singh, P.K.; Bhattacharya, B. Ion irradiation on polymer electrolyte films: Comparative study on conductivity. High Perform. Polym. 2016, 28, 1059-1063. [CrossRef]

78. Chowdhury, F.I.; Khandaker, M.U.; Amin, Y.M.; Arof, A.K. Effect of gamma radiation on the transport and structural properties of polyacrylonitrile-lithium bis(oxalato)borate films. Solid State Ion. 2017, 304, 27-39. [CrossRef]

79. Rahaman, M.H.A.; Khandaker, M.U.; Khan, Z.R.; Kufian, M.Z.; Noor, I.S.M.; Arof, A.K. Effect of gamma irradiation on poly(vinyledene difluoride)-lithium bis(oxalato)borate electrolyte. Phys. Chem. Chem. Phys. 2014, 16, 11527-11537. [CrossRef]

80. Hema, M.; Tamilselvi, P.; Pandaram, P. Conductivity enhancement in $\mathrm{SiO}_{2}$ doped PVA:PVDF nanocomposite polymer electrolyte by gamma ray irradiation. Nucl. Instrum. Methods Phys. Res. B 2017, 403, 13-20. [CrossRef]

81. Raghu, S.; Archana, K.; Sharanappa, C.; Ganesh, S.; Devendrappa, H. Electron beam and gamma ray irradiated polymer electrolyte films: Dielectric properties. J. Radiat. Res. Appl. Sci. 2016, 9, 117-124. [CrossRef]

82. Heffny, N.A.; Khandaker, M.U.; Osman, Z.; Woo, H.J.; Rabir, M.H.; Arof, A.K. Effect of kGy neutron doses on polymer composite consists of poly(vinylidene difluoride)-lithium bis(oxalato)borate. Radiat. Phys. Chem. 2021, 189, 109747. [CrossRef]

83. Sinha, M.; Goswami, M.M.; Mal, D.; Middya, T.R.; Tarafdar, S.; De, U.; Chaudhuri, S.K.; Das, D. Effect of gamma irradiation on the polymer electrolyte PEO- $\mathrm{NH}_{4} \mathrm{ClO}_{4}$. Ionics 2008, 14, 323-327. [CrossRef]

84. Rajeswari, N.; Selvasekarapandian, S.; Prabu, M.; Karthikeyan, S.; Sanjeeviraja, C. Lithium ion conducting solid polymer blend electrolyte based on bio-degradable polymers. Bull. Mater. Sci. 2013, 36, 333-339. [CrossRef]

85. Buraidah, M.H.; Arof, A.K. Characterization of chitosan/PVA blended electrolyte doped with NH 4 I. J. Non-Cryst. Solids 2011, 357, 3261-3266. [CrossRef]

86. Buraidah, M.H.; Teo, L.P.; Au Yong, C.M.; Shah, S.; Arof, A.K. Performance of polymer electrolyte based on chitosan blended with poly(ethylene oxide) for plasmonic dye-sensitized solar cell. Opt. Mater. 2016, 57, 202-211. [CrossRef]

87. Sim, L.N.; Majid, S.R.; Arof, A.K. FTIR studies of PEMA/PVdF-HFP blend polymer electrolyte system incorporated with $\mathrm{LiCF}_{3} \mathrm{SO}_{3}$ salt. Vib. Spectrosc. 2012, 58, 57-66. [CrossRef]

88. Zhu, L.; Li, J.; Jia, Y.; Zhu, P.; Jing, M.; Yao, S.; Shen, X.; Li, S.; Tu, F. Toward high performance solid-state lithium-ion battery with a promising PEO/PPC blend solid polymer electrolyte. Int. J. Energy Res. 2020, 25, 10168-10178. [CrossRef]

89. Kesavan, K.; Mathew, C.M.; Rajendran, S.; Subbu, C.; Ulaganathan, M. Solid Polymer Blend Electrolyte Based on Poly(ethylene oxide) and Poly(vinyl pyrrolidone) for Lithium Secondary Batteries. Braz. J. Phys. 2014, 45, 19-27. [CrossRef] 
90. Kesavan, K.; Mathew, C.M.; Rajendran, S.; Ulaganathan, M. Preparation and characterization of novel solid polymer blend electrolytes based on poly (vinyl pyrrolidone) with various concentrations of lithium perchlorate. Mater. Sci. Eng. B 2014, 184, 26-33. [CrossRef]

91. Saadiah, M.A.; Nagao, Y.; Samsudin, A.S. Proton $\left(\mathrm{H}^{+}\right)$transport properties of CMC-PVA blended polymer solid electrolyte doped with $\mathrm{NH}_{4} \mathrm{NO}_{3}$. Inter. J. Hydrog. Energy 2020, 45, 14880-14896. [CrossRef]

92. Balian, S.R.C.; Ahmad, A.; Mohamed, N.S. The Effect of Lithium Iodide to the Properties of Carboxymethyl k-Carrageenan/Carboxymethyl Cellulose Polymer Electrolyte and Dye-Sensitized Solar Cell Performance. Polymers 2016, 8, 163. [CrossRef]

93. Muhammad, F.H.; Subban, R.H.Y.; Winie, T. Solid solutions of hexanoyl chitosan/poly(vinyl chloride) blends and NaI for all-solid-state dye-sensitized solar cells. Ionics 2009, 25, 3373-3386. [CrossRef]

94. Bao, J.; Qu, X.; Qi, G.; Huang, Q.; Wu, S.; Tao, C.; Gao, M.; Chen, C. Solid electrolyte based on waterborne polyurethane and poly(ethylene oxide) blend polymer for all-solid-state lithium ion batteries. Solid State Ion. 2018, 320, 55-63. [CrossRef]

95. Tao, C.; Gao, M.-H.; Yin, B.-H.; Lia, B.; Huang, Y.-P.; Xua, G.; Bao, J.-J. A promising TPU/PEO blend polymer electrolyte for all-solid-state lithium ion batteries. Electrochim. Acta 2017, 257, 31-39. [CrossRef]

96. Koduru, H.K.; Marino, L.; Scarpelli, F.; Petrov, A.G.; Marinov, Y.G.; Hadjichristov, G.B.; Iliev, M.T.; Scaramuzza, N. Structural and dielectric properties of $\mathrm{NaIO}_{4}$ e Complexed PEO/PVP blended solid polymer electrolytes. Curr. Appl. Phys. 2017, 17, 1518-1531. [CrossRef]

97. Anilkumar, K.M.; Jinisha, B.; Manoj, M.; Jayalekshmi, S. Poly(ethylene oxide) (PEO)—Poly(vinyl pyrrolidone) (PVP) blend polymer based solid electrolyte membranes for developing solid state magnesium ion cells. Eur. Polym. J. 2017, 89, $249-262$. [CrossRef]

98. Senthil, R.A.; Theerthagiri, J.; Madhavan, J.; Arof, A.K. Performance characteristics of guanine incorporated PVDF-HFP/PEO polymer blend electrolytes with binary iodide salts for dye-sensitized solar cells. Opt. Mater. 2016, 58, 357-364. [CrossRef]

99. Chandra, M.V.L.; Karthikeyan, S.; Selvasekarapandian, S.; Premalatha, M.; Monisha, S. Study of PVAc-PMMA-LiCl polymer blend electrolyte and the effect of plasticizer ethylene carbonate and nanofiller titania on PVAc-PMMA-LiCl polymer blend electrolyte. J. Polym. Eng. 2017, 37, 617-631. [CrossRef]

100. Sengwa, R.J.; Choudhary, S.; Dhatarwal, P. Influences of ultrasonic- and microwave-irradiated preparation methods on the structural and dielectric properties of (PEO-PMMA) $-\mathrm{LiCF}_{3} \mathrm{SO}_{3}-\mathrm{x}$ wt\% MMT nanocomposite electrolytes. Ionics 2014, 21, 95-109. [CrossRef]

101. Guo, M.; Zhang, M.; He, D.; Hua, J.; Wang, X.; Gong, C.; Xie, X.; Xue, Z. Comb-like solid polymer electrolyte based on polyethylene glycol-grafted sulfonated polyether ether ketone. Electrochim. Acta 2017, 255, 396-404. [CrossRef]

102. Liu, T.-M.; Saikia, D.; Ho, S.-Y.; Chen, M.-C.; Kao, H.-M. High ion-conducting solid polymer electrolytes based on blending hybrids derived from monoamine and diamine polyethers for lithium solid-state batteries. RSC Adv. 2017, 7, 20373-20383. [CrossRef]

103. Ibrahim, S.; Ahmad, R.; Johan, M.R. Conductivity and optical studies of plasticized solid polymer electrolytes doped with carbon nanotube. J. Lumin. 2012, 132, 147-152. [CrossRef]

104. Imperiyka, M.; Ahmad, A.; Hanifah, S.A.; Mohamed, N.S.; Rahman, M.Y.A. Investigation of plasticized UV-curable glycidyl methacrylate based solid polymer electrolyte for photoelectrochemical cell (PEC) application. Int. J. Hydrog. Energy 2014, 39, 3018-3024. [CrossRef]

105. Fan, L.-Z.; Wang, X.-L.; Long, F. All-solid-state polymer electrolyte with plastic crystal materials for rechargeable lithium-ion battery. J. Power Sources 2009, 189, 775-778. [CrossRef]

106. Machado, G.O.; Ferreira, H.C.A.; Pawlicka, A. Influence of plasticizer contents on the properties of HEC-based solid polymeric electrolytes. Electrochim. Acta 2005, 50, 3827-3831.

107. Kim, J.S.; Lim, J.K.; Park, J.S. Enhancement of Mechanical Stability and Ionic Conductivity of Chitosan-based Solid Polymer Electrolytes Using Silver Nanowires as Fillers. Bull. Korean Chem. Soc. 2019, 40, 898-905. [CrossRef]

108. Aziz, S.B.; Asnawi, A.S.F.M.; Mohammed, P.A.; Abdulwahid, R.T.; Yuhanees, M.; Yusof, Y.M.; Abdullah, R.M.; Kadir, M.F.Z. Impedance, circuit simulation, transport properties and energy storage behavior of plasticized lithium ion conducting chitosan based polymer electrolytes. Polym. Test. 2021, 101, 107286. [CrossRef]

109. Li, Y.; Wang, J.; Tang, J.; Liu, Y.; He, Y. Conductive performances of solid polymer electrolyte films based on $\mathrm{PVB} / \mathrm{LiClO}_{4}$ plasticized by PEG200, PEG400 and PEG600. J. Power Sources 2009, 187, 305-311. [CrossRef]

110. Jibreel, U.M.; Bhattacharya, B.; Singh, P.K. Synthesis, Characterization, and Detailed Studies on Plasticized Poly(ethyl methacrylate): $\mathrm{NH}_{4} \mathrm{I}$ Polymer Electrolyte. Adv. Polym. Technol. 2018, 37, 542-546. [CrossRef]

111. Anuar, N.K.; Subban, R.H.Y.; Mohamed, N.S. Properties of PEMA-NH${ }_{4} \mathrm{CF}_{3} \mathrm{SO}_{3}$ added to BMATSFI ionic liquid. Materials 2012, 5, 2609-2620. [CrossRef]

112. Wang, H.; Lin, C.; Yan, X.; Wu, A.; Shen, S.; Wei, G.; Zhang, J. Mechanical property-reinforced PEO $/ \mathrm{PVDF} / \mathrm{LiClO}_{4} / \mathrm{SN}$ blend all solid polymer electrolyte for lithium ion batteries. J. Electroanaly. Chem. 2020, 869, 114156. [CrossRef]

113. Reddy, M.J.; Kumar, J.S.; Rao, U.V.S.; Chu, P.P. Structural and ionic conductivity of PEO blend PEG solid polymer electrolyte. Solid State Ion. 2006, 177, 253-256. [CrossRef]

114. Widstrom, M.D.; Ludwig, K.B.; Matthews, J.E.; Jarry, A.; Erdi, M.; Cresce, A.V.; Rubloff, G.; Kofinas, P. Enabling high performance all-solid-state lithium metal batteries using solid polymer electrolytes plasticized with ionic liquid. Electrochim. Acta 2020, 345, 136-156. [CrossRef] 
115. Wang, W.; Fang, Z.; Zhao, M.; Peng, Y.; Zhang, J.; Guan, S. Solid polymer electrolytes based on the composite of PEO-LiFSI and organic ionic plastic crystal. Chem. Phys. Lett. 2020, 747, 137335. [CrossRef]

116. Abdullah, O.G.; Ahmed, H.T.; Tahir, D.A.; Jamal, G.M.; Mohamad, A.H. Influence of PEG plasticizer content on the protonconducting PEO:MC-NH${ }_{4} \mathrm{I}$ blend polymer electrolytes based films. Results Phys. 2021, 23, 104073. [CrossRef]

117. Ahmed, H.T.; Abdullah, O.G. Structural and ionic conductivity characterization of PEO:MC-NH $\mathrm{I}_{4}$ proton-conducting polymer blend electrolytes based films. Results Phys. 2020, 16, 102861. [CrossRef]

118. Pal, P.; Ghosh, A. Investigation of ionic conductivity and relaxation in plasticized $\mathrm{PMMA}-\mathrm{LiClO}_{4}$ solid polymer electrolytes. Solid State Ion. 2018, 319, 117-124. [CrossRef]

119. Rajendran, S.; Sivakumar, M.; Subadevi, R. Li-ion conduction of plasticized PVA solid polymer electrolytes complexed with various lithium salts. Solid State Ion. 2004, 167, 335-339. [CrossRef]

120. Johan, M.R.; Oon, H.S.; Ibrahim, S.; Yassin, S.M.M.; Tay, Y.H. Effects of $\mathrm{Al}_{2} \mathrm{O}_{3}$ nanofiller and EC plasticizer on the ionic conductivity enhancement of solid PEO-LiCF $3 \mathrm{SO}_{3}$ solid polymer electrolyte. Solid State Ion. 2011, 196, 41-47. [CrossRef]

121. Liew, C.-W.; Ramesh, S.; Ramesh, K.; Arof, A.K. Preparation and characterization of lithium ion conducting ionic liquid-based biodegradable corn starch polymer electrolytes. J. Solid State Electrochem. 2012, 16, 1869-1875. [CrossRef]

122. Gupta, S.; Varshney, P.K. Effect of plasticizer on the conductivity of carboxymethyl cellulose-based solid polymer electrolyte. Polym. Bull. 2019, 76, 6169-6178. [CrossRef]

123. Liew, C.-W.; Arifin, K.H.; Kawamura, J.; Iwai, Y.; Ramesh, S.; Arof, A.K. Effects of halide anions in ionic liquid added poly(vinyl alcohol)-based ion conductors for electrical double layer capacitors. J. Non-Cryst. Solids 2017, 458, 97-106. [CrossRef]

124. Buraidah, M.H.; Teo, L.P.; Arof, A.K. Determining the potential of 55 wt. $\%$ chitosan- 45 wt. $\%$ NH$_{4} \mathrm{I}_{\text {biopolymer electrolyte for }}$ application in dye-sensitized solar cells. Mol. Cryst. Liq. Cryst. 2019, 695, 97-106. [CrossRef]

125. Polu, A.R.; Singh, P.K. Improved ion dissociation and amorphous region of PEO based solid polymer electrolyte by incorporating tetracyanoethylene. Mat. Today Proc. 2020. [CrossRef]

126. Singh, P.K.; Bhattacharya, B.; Nagarale, R.K.; Kim, K.-W.; Rhee, H.-W. Synthesis, characterization and application of biopolymerionic liquid composite membranes. Synth. Met. 2010, 160, 139-142. [CrossRef]

127. Senthil, R.A.; Theerthagiri, J.; Madhavan, J. Optimization of performance characteristics of 2-mercaptopyridine-doped polyvinylidene fluoride (PVDF) polymer electrolytes for dye-sensitized solar cells. J. Non-Cryst. Solids 2014, 406, 133-138. [CrossRef]

128. Senthil, R.A.; Theerthagiri, J.; Madhavan, J.; Ganesan, S.; Arof, A.K. Influence of organic additive to PVDF-HFP mixed iodide electrolytes on the photovoltaic performance of dye-sensitized solar cells. J. Phys. Chem. Solids 2017, 101, 18-24. [CrossRef]

129. Tuhania, P.; Singh, P.K.; Bhattacharya, B.; Dhapola, P.S.; Yadav, S.; Shukla, P.K.; Gupta, M. PVDF-HFP and 1-ethyl-3methylimidazolium thiocyanate-doped polymer electrolyte for efficient supercapacitors. High Perform. Polym. 2018, 30, 911-917. [CrossRef]

130. Xue, Z.; He, D.; Xie, X. Poly(ethylene oxide)-based electrolytes for lithium-ion batteries. J. Mater. Chem. A 2015, 3, $19218-19253$. [CrossRef]

131. He, R.; Echeverri, M.; Ward, D.; Zhu, Y.; Kyu, T. Highly conductive solvent-free polymer electrolyte membrane for lithium-ion batteries: Effect of prepolymer molecular weight. J. Membr. Sci. 2016, 498, 208-217. [CrossRef]

132. Tan, C.G.; Siew, W.O.; Pang, W.L.; Osman, Z.; Chew, K.W. The effects of ceramic fillers on the PMMA-based polymer electrolyte systems. Ionics 2007, 13, 361-364. [CrossRef]

133. Ahmad, S.; Bohidar, H.B.; Ahmad, S.; Agnihotry, S.A. Role of fumed silica on ion conduction and rheology in nanocomposite polymeric electrolytes. Polymer 2006, 47, 3583-3590. [CrossRef]

134. Wimalaweera, K.K.; Seneviratne, V.A.; Dissanayake, M.A.K.L. Effect of $\mathrm{Al}_{2} \mathrm{O}_{3}$ ceramic filler on thermal and transport properties of poly(ethylene oxide)-lithium perchlorate solid polymer electrolyte. Procedia Eng. 2017, 215, 109-114. [CrossRef]

135. Croce, F.; Persi, L.; Scrosati, B.; Serraino-Fiory, F.; Plichta, E.; Hendrickson, M.A. Role of the ceramic fillers in enhancing the transport properties of composite polymer electrolytes. Electrochim. Acta 2001, 46, 2457-2461. [CrossRef]

136. Singh, P.; Saroj, A.L. Effect of $\mathrm{SiO}_{2}$ Nano-particles on Plasticized Polymer Blend Electrolytes: Vibrational, Thermal, and Ionic Conductivity Study. Polym. Plast. Technol. Mater. 2021, 6, 298-305.

137. Li, J.; Lian, K. The effect of $\mathrm{SiO}_{2}$ additives on solid hydroxide ion-conducting polymer electrolytes: A Raman microscopy study. Phys. Chem. Chem. Phys. 2018, 20,7148-7155. [CrossRef]

138. Kim, S.-H.; Choi, K.-H.; Cho, S.-J.; Kil, E.-H.; Lee, S.-Y. Mechanically compliant and lithium dendrite growth-suppressing composite polymer electrolytes for flexible lithium-ion batteries. J. Mater. Chem. A 2013, 1, 4949-4955. [CrossRef]

139. Cui, J.; Zhou, Z.; Jia, M.; Chen, X.; Shi, C.; Zhao, N.; Guo, X. Solid polymer electrolytes with flexible framework of $\mathrm{SiO}_{2}$ nanofibers for highly safe solid lithium batteries. Polymers 2020, 12, 1324. [CrossRef] [PubMed]

140. Jiang, Y.; Yan, X.; Ma, Z.; Mei, P.; Xiao, W.; You, Q.; Zhang, Y. Development of the PEO based solid polymer electrolytes for all-solid state lithium ion batteries. Polymers 2018, 10, 1237. [CrossRef]

141. Jung, Y.-C.; Lee, S.-M.; Choi, J.-H.; Jang, S.S.; Kim, D.-W. All solid-state lithium batteries assembled with hybrid solid electrolytes. J. Electrochim. Soc. 2015, 162, A704-A710. [CrossRef]

142. Wang, W.; Yi, F.; Fici, A.J.; Laine, R.M.; Kieffer, J. Lithium ion conducting poly(ethylene oxide)-based solid electrolytes containing active or passive ceramic nanoparticles. J. Phys. Chem. C 2017, 121, 2563-2573. [CrossRef] 
143. Choi, J.-H.; Lee, C.-H.; Yu, J.-H.; Doh, C.-H.; Lee, S.-M. Enhancement of ionic conductivity of composite membranes for all-solidstate lithium rechargeable batteries incorporating tetragonal $\mathrm{Li}_{7} \mathrm{La}_{3} \mathrm{Zr}_{2} \mathrm{O}_{12}$ into a polyethylene oxide matrix. J. Power Sources 2015, 274, 458-463. [CrossRef]

144. Liu, W.; Liu, N.; Sun, J.; Hsu, P.-C.; Li, Y.; Lee, H.-W.; Cui, Y. Ionic conductivity enhancement of polymer electrolytes with ceramic nanowire fillers. Nano Lett. 2015, 15, 2740-2745. [CrossRef] [PubMed]

145. Zhang, Q.; Liu, K.; Li, J.; Ma, C.; Zhou, L.; Du, Y. Study of a composite solid electrolyte made from a new pyrrolidone-containing polymer and LLZTO. J. Colloid Interface Sci. 2020, 580, 389-398. [CrossRef]

146. Wang, H.; Zhao, N.; Bi, Z.; Gao, S.; Dai, Q.; Yang, T.; Wang, J.; Jia, Z.; Peng, Z.; Huang, J.; et al. Clear representation of surface pathway reactions at $\mathrm{Ag}$ nanowire cathodes in all-solid $\mathrm{Li}_{2} \mathrm{O}_{2}$ batteries. ACS Appl. Mater. Interfaces 2021, 13, 39157-39164. [CrossRef] [PubMed]

147. Shen, L.; Wang, L.; Wang, Z.; Jin, C.; Peng, L.; Pan, X.; Sun, J.; Yang, R. Preparation and characterization of Ga and Sr co-doped $\mathrm{Li}_{7} \mathrm{La}_{3} \mathrm{Zr}_{2} \mathrm{O}_{12}$ garnet-type solid electrolyte. Solid State Ion. 2019, 339, 114992. [CrossRef]

148. Huang, W.L.; Zhao, N.; Bi, Z.J.; Shi, C.; Guo, X.X.; Fan, L.-Z.; Nan, C.-W. Can we find solution to eliminate Li penetration through solid garnet electrolytes? Mater. Today Nano 2020, 10, 100075. [CrossRef]

149. Ren, Y.; Shen, Y.; Lin, Y.; Nan, C.-W. Direct observation of lithium dendrites inside garnet-type lithium-ion solid electrolyte. Electrochem. Commun. 2015, 57, 27-30. [CrossRef]

150. Shen, F.; Guo, W.; Zeng, D.; Sun, Z.; Gao, J.; Li, J.; He, B.; Han, X. A simple and highly efficient method toward high-density garnet-type LLZTO solid-state electrolyte. ACS Appl. Mater. Interfaces 2020, 12, 30313-30319. [CrossRef] [PubMed]

151. Karabelli, D.; Birke, K.P.; Weeber, M. A performance and cost overview of selected solid-state electrolytes: Race between polymer electrolytes and inorganic sulfide electrolytes. Batteries 2021, 7, 18. [CrossRef]

152. Nguyen, Q.H.; Luu, V.T.; Nguyen, H.L.; Lee, Y.-W.; Cho, Y.; Kim, S.Y.; Jun, Y.-S.; Ahn, W. $\mathrm{Li}_{7} \mathrm{La}_{3} \mathrm{Zr}_{2} \mathrm{O}_{12}$ garnet solid polymer electrolyte for highly stable all-solid-state batteries. Front. Chem. 2021, 8, 619832. [CrossRef]

153. Zhang, W.; Wang, X.; Zhang, Q.; Wang, L.; Xu, Z.; Li, Y.; Huang, S. Li $\mathrm{La}_{3} \mathrm{Zr}_{2} \mathrm{O}_{12}$ ceramic nanofiber-incorporated solid polymer electrolytes for flexible lithium batteries. ACS Appl. Energy Mater. 2020, 3, 5238-5246. [CrossRef]

154. Cha, J.H.; Didwal, P.N.; Kim, J.M.; Chang, D.R.; Park, C.-J. Poly(ethylene oxide)-based composite solid polymer electrolyte containing $\mathrm{Li}_{7} \mathrm{La}_{3} \mathrm{Zr}_{2} \mathrm{O}_{12}$ and poly(ethylene glycol) dimethyl ether. J. Membr. Sci. 2020, 595, 117538. [CrossRef]

155. Keller, M.; Appetecchi, G.B.; Kim, G.-T.; Sharova, V.; Schneider, M.; Schuhmacher, J.; Roters, A.; Passerini, S. Electrochemical performance of a solvent-free hybrid ceramic polymer electrolyte based on $\mathrm{Li}_{7} \mathrm{La}_{3} \mathrm{Zr}_{2} \mathrm{O}_{12}$ in $\mathrm{P}(\mathrm{EO})_{15} \mathrm{LiTFSI}$. J. Power Sources 2017, 353, 287-297. [CrossRef]

156. Zhou, D.; Zhang, M.; Su, F.; Arlt, T.; Frerichs, J.E.; Dong, K.; Wang, J.; Hilger, A.; Wilde, F.; Kolek, M.; et al. Performance and beghavior of LLZO-based composite polymer electrolyte for lithium metal electrode with high capacity utilization. Nano Energy 2020, 77, 105196. [CrossRef]

157. Zhang, X.; Xu, B.-Q.; Lin, Y.-H.; Shen, Y.; Li, L.; Nan, C.-W. Effects of $\mathrm{Li}_{6.75} \mathrm{La}_{3} \mathrm{Zr}_{1.75} \mathrm{Ta}_{0.25} \mathrm{O}_{12}$ on chemical and electrochemical properties of polyacrylonitrile-based solid electrolytes. Solid State Ion. 2018, 327, 32-38. [CrossRef]

158. Zhang, J.; Zang, X.; Wen, H.; Dong, T.; Chai, J.; Li, Y.; Chen, B.; Zhao, J.; Dong, S.; Ma, J.; et al. High-voltage and free-standing poly(propylene carbonate) $/ \mathrm{Li}_{6.75} \mathrm{La}_{3} \mathrm{Zr}_{1.75} \mathrm{Ta}_{0.25} \mathrm{O}_{12}$ composite solid electrolyte for wide temperature range and flexible solid lithium ion battery. J. Mater. Chem. A 2017, 5, 4940-4948. [CrossRef]

159. Piana, G.; Bella, F.; Geobaldo, F.; Meligrana, G.; Gerbaldi, C. PEO/LAGP hybrid solid polymer electrolytes for ambient temperature lithium batteries by solvent-free, "one-pot" preparation. J. Energy Storage 2019, 26, 100947. [CrossRef]

160. Sung, B.-J.; Didwal, P.N.; Verma, R.; Nguyen, A.-G.; Chang, D.R.; Park, C.-J. Composite solid electrolyte comprising poly(propylene carbonate) and $\mathrm{Li}_{1.5} \mathrm{Al}_{0.5} \mathrm{Ge}_{1.5}\left(\mathrm{PO}_{4}\right)_{3}$ for long-life all-solid-state Li-ion batteries. Electrochim. Acta 2021, 392, 139007. [CrossRef]

161. Pignanelli, F.; Romero, M.; Esteves, M.; Luciana, F.-W.; Faccio, R.; Mombrú, A.W. Lithium titanate nanotubes as active fillers for lithium-ion polyacrylonitrile solid polymer electrolytes. Ionics 2019, 25, 2607-2614. [CrossRef]

162. Boaretto, N.; Meabe, L.; Martinez-Ibanez, M.; Armand, M.; Zhang, H. Polymer electrolytes for rechargeable batteries: From nanocomposite to nanohybrid. J. Electrochem. Soc. 2020, 167, 070524. [CrossRef]

163. Zheng, J.; Tang, M.; Hu, Y.-Y. Lithium ion pathway within $\mathrm{Li}_{7} \mathrm{La}_{3} \mathrm{Zr}_{2} \mathrm{O}_{12}$-polyethylene oxide composite electrolytes. Angezw. Chem. 2016, 55, 12538-12542. [CrossRef] [PubMed]

164. Zheng, J.; Dang, H.; Feng, X.; Chien, P.-H.; Hu, Y.-Y. Li-ion transport in a representative ceramic-polymer-plasticizer composite electrolyte: $\mathrm{Li}_{7} \mathrm{La}_{3} \mathrm{Zr}_{2} \mathrm{O}_{12}$-polyethylene oxide-tetraethylene glycol dimethyl ether. J. Mater. Chem. A. 2017, 5, 18457-18463. [CrossRef]

165. Cai, D.; Wang, D.; Chen, Y.; Zhang, S.; Wang, X.; Xia, X.; Tu, J. A highly ion-conductive three-dimensional LLZAO-PEO/LiTFSI solid electrolyte for high-performance solid-state batteries. Chem. Eng. J. 2020, 394, 124993. [CrossRef]

166. Pareek, T.; Dwivedi, S.; Ahmad, S.A.; Badole, M.; Kumar, S. Effect of NASICON-type LiSnZr $\left(\mathrm{PO}_{4}\right)_{3}$ ceramic filler on the ionic conductivity and electrochemical behavior of PVDF based composite electrolyte. J. Alloys Compd. 2020, 824, 153991. [CrossRef]

167. Zhao, R.; Wu, Y.; Liang, Z.; Gao, L.; Xia, W.; Zhao, Y.; Zou, R. Metal-organic frameworks for solid-state electrolytes. Energy Environ. Sci. 2020, 13, 2386-2403. [CrossRef] 
168. Gerbaldi, C.; Nair, J.R.; Kulandainathan, M.A.; Kumar, R.S.; Ferrara, C.; Mustarellic, P.; Stephan, A.M. Innovative high performing metal organic framework (MOF)-laden nanocomposite polymer electrolytes for all-solid-state lithium batteries. J. Mater. Chem. A 2014, 2, 9948-9954. [CrossRef]

169. Angulakshmi, N.; Zhou, Y.; Suriyakumar, S.; Dhanalakshmi, R.B.; Satishrajan, M.; Alwarappan, S.; Alkordi, M.H.; Stephan, A.M. Microporous metal-organic framework (MOF)-based composite polymer electrolyte (CPE) mitigating lithium dendrite formation in all-solid-state-lithium batteries. ACS Omega 2020, 5, 7885-7894. [CrossRef] [PubMed]

170. Kumar, R.S.; Raja, M.; Kulandainathan, M.A.; Stephan, A.M. Metal organic framework-laden composite polymer electrolytes for efficient and durable all-solid-state-lithium batteries. RSC Adv. 2014, 4, 26171-26175. [CrossRef]

171. Wang, Z.; Zhou, H.; Meng, C.; Xiong, W.; Cai, Y.; Hu, P.; Pang, H.; Yuan, A. Enhancing ion transport: Function of ionic liquid decorated MOFs in polymer electrolytes for all solid-state lithium batteries. ACS Appl. Energy Mater. 2020, 3, 4265-4274. [CrossRef]

172. Angulakshmi, N.; Kumar, R.S.; Kulandainathan, M.A.; Stephan, A.M. Composite polymer electrolytes encompassing metal organic frameworks: A new strategy for all solid-state lithium batteries. J. Phys. Chem. C 2014, 118, 24240-24247. [CrossRef]

173. Yuan, C.; Li, J.; Han, P.; Lai, Y.; Zhang, Z.; Liu, J. Enhanced electrochemical performance of poly(ethylene oxide) based composite polymer electrolyte by incorporation of nano-sized metal-organic framework. J. Power Sources 2013, 240, 653-658. [CrossRef]

174. Zhao, Y.; Wang, L.; Zhou, Y.; Liang, Z.; Tavajohi, N.; Li, B.; Li, T. Solid polymer electrolytes with high conductivity and transference number of Li ions for Li-based rechargeable batteries. Adv. Sci. 2021, 8, 2003675. [CrossRef] [PubMed]

175. Li, L.; Deng, Y.; Chen, G. Status and prospect of garnet/polymer solid composite electrolytes for all-solid-state lithium batteries. J. Energy Chem. 2020, 50, 154-177. [CrossRef]

176. Barbosa, J.C.; Goncalves, R.; Costa, C.M.; Bermudez, V.d.Z.; Fidalgo-Marijuan, A.; Zhang, Q.; Lanceros-Mendez, S. Metal-organic frameworks and zeolite materials as active fillers for lithium-ion battery solid polymer electrolytes. Mater. Adv. 2021, 2, 3790-3805. [CrossRef]

177. Capiglia, C.; Mustarelli, P.; Quartarone, E.; Tomasi, C.; Magistris, A. Effects of nanoscale SiO on the thermal and transport properties of solvent-free, poly(ethylene oxide) (PEO)-based polymer electrolytes. Solid State Ion. 1999, 118, 73-79. [CrossRef]

178. Wei, W.; Li, L.; Zhang, L.; Hong, L.; He, G. An all-solid-state Li-organic battery with quinone-based polymer cathode and composite polymer electrolyte. Electrochem. Commun. 2018, 90, 21-25. [CrossRef]

179. Jeyabanua, K.; Sundaramahalingam, K.; Devendran, P.; Manikandan, A.; Nallamuthu, N. Effect of electrical conductivity studies for CuS nanofillers mixed magnesium ion based PVA-PVP blend polymer solid electrolyte. Phys. B Condens. Matter. 2019, 572, 129-138. [CrossRef]

180. Dhatarwala, P.; Choudhary, S.; Sengwa, R.J. Electrochemical performance of $\mathrm{Li}^{+}$-ion conducting solid polymer electrolytes based on PEO-PMMA blend matrix incorporated with various inorganic nanoparticles for the lithium ion batteries. Compos. Commun. 2018, 10, 11-17. [CrossRef]

181. Choudhary, S.; Sengwa, R.J. Effects of different inorganic nanoparticles on the structural, dielectric and ion transportation properties of polymers blend based nanocomposite solid polymer electrolytes. Electrochim. Acta 2017, 247, 924-941. [CrossRef]

182. Li, L.; Shan, Y.; Yang, X. New insights for constructing solid polymer electrolytes with ideal lithium-ion transfer channels by using inorganic filler. Mater. Today Commun. 2020, 26, 101910. [CrossRef]

183. Dhatarwala, P.; Sengwa, R.J.; Choudhary, S. Effect of intercalated and exfoliated montmorillonite clay on the structural, dielectric and electrical properties of plasticized nanocomposite solid polymer electrolytes. Compos. Commun. 2017, 5, 1-7. [CrossRef]

184. Zhang, X.; Wang, X.; Liu, S.; Tao, Z.; Chen, J. A novel PMA/PEG-based composite polymer electrolyte for all-solid-state sodium ion batteries. Nano Res. 2018, 11, 62244-66251. [CrossRef]

185. Koduru, H.K.; Iliev, M.T.; Kondamareddy, K.K.; Karashanova, D.; Vlakhov, T.; Zhao, X.Z.; Scaramuzza, N. Investigations on Poly(ethylene oxide) (PEO)—blend based solid polymer electrolytes for sodium ion batteries. J. Phys. Conf. Ser. 2016, 764, 012006. [CrossRef]

186. Hu, J.; Chen, K.; Zhenguo Yao, Z.; Li, C. Unlocking solid-state conversion batteries reinforced by hierarchical microsphere stacked polymer electrolyte. Sci. Bull. 2021, 66, 694-707. [CrossRef]

187. Zhao, Y.; Wu, C.; Peng, G.; Chen, X.; Yao, X.; Bai, Y.; Wu, F.; Chen, S.; Xu, X. A new solid polymer electrolyte incorporating $\mathrm{Li}_{10} \mathrm{GeP}_{2} \mathrm{~S}_{12}$ into a polyethylene oxide matrix for all-solid-state lithium batteries. J. Power Sources 2016, 301, 47-53. [CrossRef]

188. Suriyakumar, S.; Kanagaraj, M.; Angulakshmi, N.; Kathiresan, M.; Nahm, K.S.; Walkowiak, M.; Wasinski, K.; Poltrolniczak, P.; Stephan, A.M. Charge-discharge studies of all-solid-state $\mathrm{Li} / \mathrm{LiFePO}_{4}$ cells with PEO-based composite electrolytes encompassing metal organic frameworks. RSC Adv. 2016, 6, 97180-97186. [CrossRef]

189. Blazejczyk, A.; Wieczorek, W.; Kovarsky, R.; Golodnitsky, D.; Peled, E.; Scanlon, L.G.; Appetecchi, G.B.; Scrosati, B. Novel Solid Polymer Electrolytes with Single Lithium-Ion Transport. J. Electrochem. Soc. 2004, 151, A1762-A1766. [CrossRef]

190. Johansson, P. Anion cryptands: A way to increased cation transport in polymer electrolytes. Electrochim. Acta 2003, 48, 2291-2294. [CrossRef]

191. Mazor, H.; Golodnitsky, D.; Peled, E.; Wieczorek, W.; Scrosati, B. A search for a single-ion-conducting polymer electrolyte: Combined effect of anion trap and inorganic filler. J. Power Sources 2008, 178, 736-743. [CrossRef]

192. Kufian, M.Z.; Arof, A.K. Effect of calix[6]arene on charge discharge behaviour of lithium air cell based on PAN-LiBOB gel polymer electrolyte. Mater. Technol. 2014, 29, A114-A117. [CrossRef]

193. Kalita, M.; Bukat, M.; Ciosek, M.; Siekierski, M.; Chung, S.H.; Rodr'1guez, T.; Greenbaum, S.G.; Kovarsky, R.; Golodnitsky, D.; Peled, E.; et al. Effect of calixpyrrole in PEO-LiBF 4 polymer electrolytes. Electrochim. Acta 2005, 50, 3942-3948. [CrossRef] 
194. Panero, S.; Scrosati, B.; Sumathipala, H.H.; Wieczorek, W. Dual-composite polymer electrolytes with enhanced transport properties. J. Power Sources 2007, 167, 510-514. [CrossRef]

195. Won, J.; Lee, K.M.; Kang, Y.S.; Chang, S.-K.; Kim, C.K.; Kim, C.K. Anion complexation by calix[4]pyrrole in solid polymer electrolytes. Macromol. Res. 2006, 14, 404-407. [CrossRef]

196. Chen, S.; Feng, F.; Yin, Y.; Lizo, X.; Ma, Z. Plastic crystal polymer electrolytes containing boron based anion acceptors for room temperature all-solid-state sodium-ion batteries. Energy Storage Mater. 2019, 22, 57-65. [CrossRef]

197. Eslah, S.; Nouri, M. Synthesis and Characterization of tungsten trioxide/polyaniline/polyacrylonitrile composite nanofibers for application as a counter electrode of DSSCs. Russ. J. Electrochem. 2019, 55, 291-304. [CrossRef]

198. Li, Q.; Wu, J.; Tang, Q.; Lan, Z.; Li, L.; Lin, J.; Fan, L. Application of microporous polyaniline counter electrode for dye-sensitized solar cells. Electrochem. Commun. 2008, 10, 1299-1302. [CrossRef]

199. Dissanayake, M.A.K.L.; Kumari, J.M.K.W.; Senadeera, G.K.R.; Jaseetharan, T.; Mellander, B.-E.; Albinson, I.; Furlani, M. Polyaniline (PANI) mediated cation trapping effect on ionic conductivity enhancement in poly(ethylene oxide) based solid polymer electrolytes with application in solid state dye sensitized solar cells. React. Funct. Polym. 2020, 155, 104683. [CrossRef]

200. Tan, J.; Ao, X.; Dai, A.; Yuan, Y.; Zhuo, H.; Lu, H.; Zhuang, L.; Ke, Y.; Su, C.; Peng, X.; et al. Polycation ionic liquid tailored PEO-based solid polymer electrolytes for high temperature lithium metal batteries. Energy Storage Mater. 2020, 33, 173-180. [CrossRef] 